\title{
1 Ionic Liquids Combined with Membrane Separation Processes: A
}

\section{Review}

\author{
Xueru Yan ${ }^{1}$, Stéphane Anguille ${ }^{1}$, Marc Bendahan ${ }^{2}$ and Philippe Moulin ${ }^{1 *}$ \\ ${ }^{1}$ Aix Marseille Univ, CNRS, Centrale Marseille, M2P2, Equipe Procédés Membranaires (EPM), Aix en \\ Provence Cedex, France \\ ${ }^{2}$ Aix Marseille Univ, Université de Toulon, CNRS, IM2NP, Marseille, France \\ *Corresponding author. \\ E-mail address: philippe.moulin@univ-amu.fr (Philippe Moulin)
}

\begin{abstract}
:
Combination of membrane processes and ionic liquids have received more and more attention in pollutants removal because it enhances separation efficiency but also broaden their research and application areas. This review provides a first and systematical summary on ionic liquids incorporate in membrane processes for VOCs or $\mathrm{CO}_{2}$ separation, including supported ionic liquid membranes (SILMs), ILs composite polymer membranes (ILPMs), ionic liquids composite mixed matrix membranes (ILMMMs), poly(ionic liquid)s membranes (PILMs), ionic liquid gel membranes (ILGMs), and ionic liquid membrane contactors (ILMCs). Moreover, a new concept, combination of the membrane separation processes and absorption processes of ionic liquids, is introduced. Those separation processes are described detailly and compared with other conventional processes. With their separation performances and the processes of regeneration, membrane contactor shows stronger competitive advantages and it has the potential to be a major process in VOCs and $\mathrm{CO}_{2}$ separation. The advantages and disadvantages posed by all present ionic liquid membrane processes are summarized. Finally, challenges and opportunities in ionic liquid membrane separation processes are identified and discussed.
\end{abstract}

Keywords: Membrane separation processes, Ionic liquids, $\mathrm{VOCs}$ or $\mathrm{CO}_{2}$ removing, Regeneration 


\section{Contents}

2 Ionic Liquids Combinate with Membrane Separation Processes: A Review ……........................................ 1

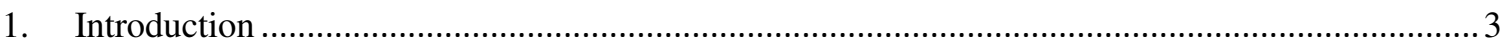

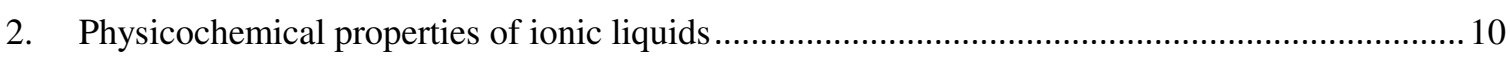

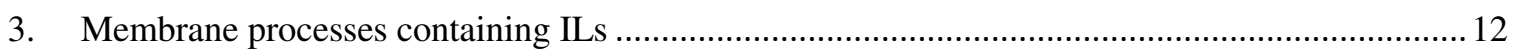

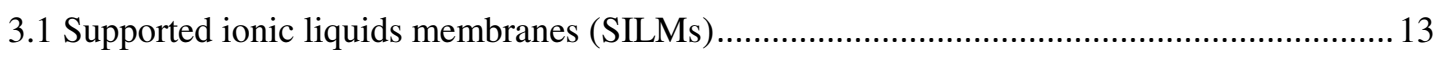

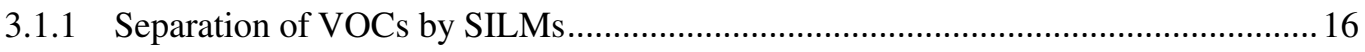

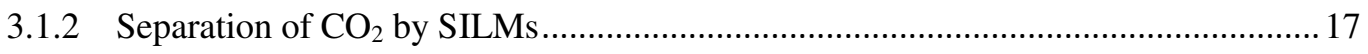

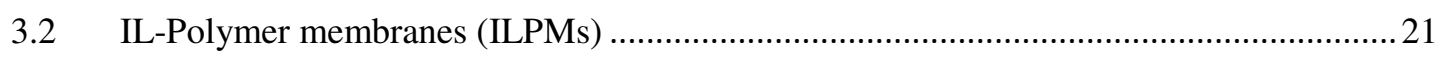

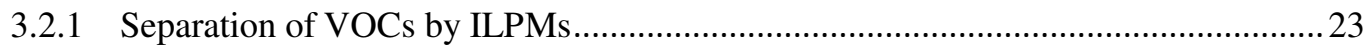

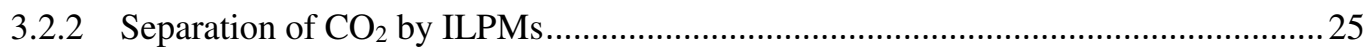

3.3 Ionic liquids composited mixed matrix membranes (ILMMMs) …………......................2

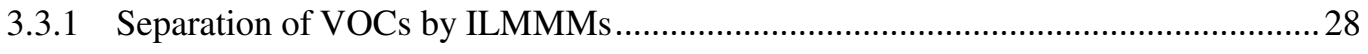

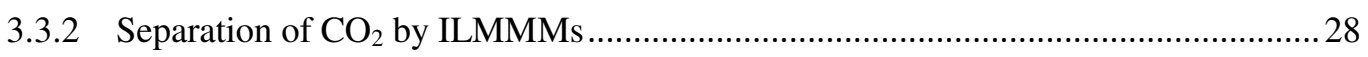

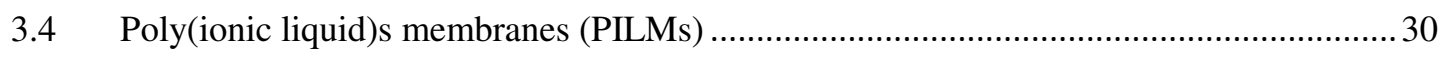

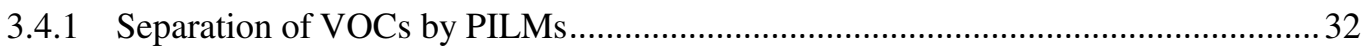

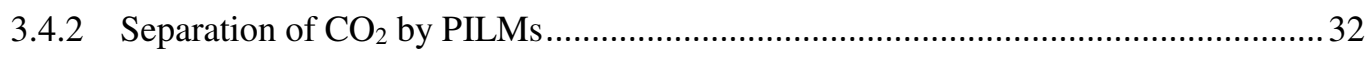

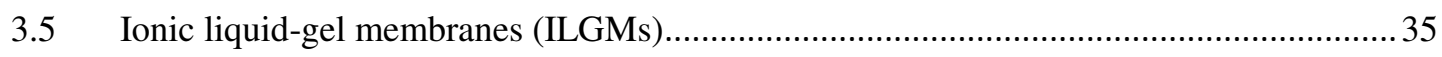

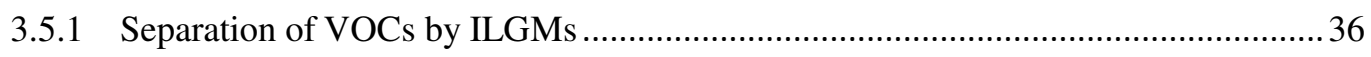

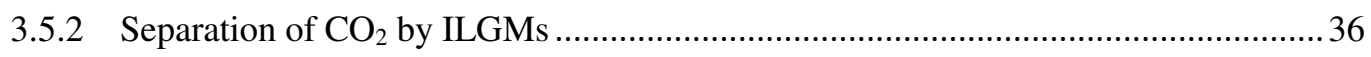

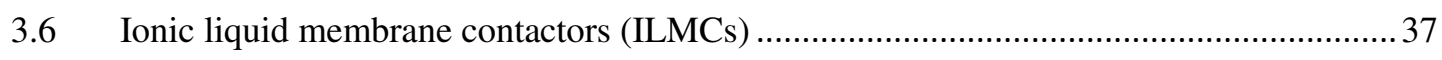

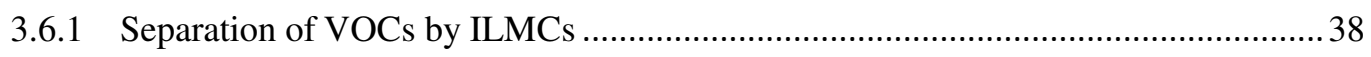

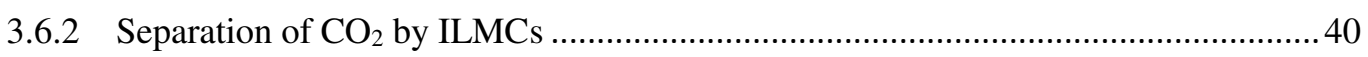

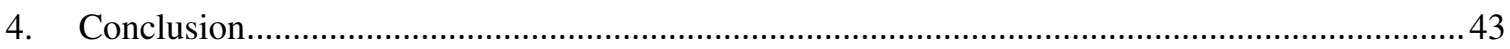

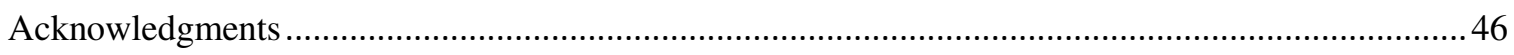

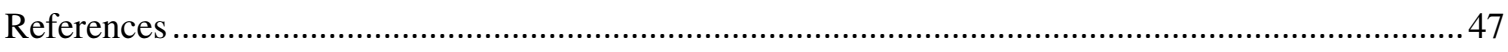




\section{Introduction}

Environment pollution and climate change caused by volatile organic compounds (VOCs) and carbon dioxide $\left(\mathrm{CO}_{2}\right)$ have attracted increasing concerns. VOCs with the boiling point ranging from 323 to $523 \mathrm{~K}$ are among the main air pollutants $[1,2]$. They include a multitude of substances and are easily evaporate at room temperature [2 - 4]. The volatility of VOCs allows them to spread around the sources of pollution. They often cause serious environmental problems, such as greenhouse effect [5 - 7], photochemical smog [8, 9], stratospheric ozone depletion [10 - 13] and so on. These potential risks have resulted in stricter environmental legislations in most countries, forcing industry companies to treat their air emissions before discharging them into the atmosphere [14]. Table 1 shows the common VOCs discharged into the atmosphere and the negative effects on human health. Therefore, developing effective VOCs elimination techniques and optimizing VOCs removing processes become societal issues. The representations of VOCs were selected based on (i) by sources of emissions and dangerous to human health and (ii) the concentrations of VOCs make immediately dangerous to health (National Institute of Occupational Safety and Health).

Table 1. Health effects of common VOCs [15 - 23].

\begin{tabular}{|c|c|c|}
\hline Classification & Representation & Health Effects \\
\hline Aldehydes & $\begin{array}{l}\text { Acetaldehyde } \\
\text { Formaldehyde }\end{array}$ & $\begin{array}{l}\text {-Nasal tumors } \\
\text {-Predecessor of ozone } \\
\text {-Irritation of eyes, skin, and throat }\end{array}$ \\
\hline Ketones & Ethyl butyl ketone & $\begin{array}{l}\text {-Central nervous system depression } \\
\text {-Headache and nausea }\end{array}$ \\
\hline Aromatic compounds & $\begin{array}{l}\text { Benzene } \\
\text { Toluene } \\
\text { O-xylene and P-xylene } \\
\text { Ethylbenzene }\end{array}$ & $\begin{array}{l}\text {-Carcinogen } \\
\text {-Damage the ozone layer } \\
\text {-Irritation the central nervous system } \\
\text {-Produce photochemical smog, and } \\
\text { pose mutagenic hazards }\end{array}$ \\
\hline Halogenated VOCs & $\begin{array}{l}\text { Carbon tetrachloride } \\
\text { Trichloroethylene } \\
\text { Tetrachloroethylene }\end{array}$ & $\begin{array}{l}\text {-Strong bioaccumulation potential } \\
\text {-Cause greenhouse effects }\end{array}$ \\
\hline
\end{tabular}




\begin{tabular}{|c|c|c|}
\hline Alcohols & $\begin{array}{l}\text { Isopropyl alcohol } \\
\text { Methanol }\end{array}$ & $\begin{array}{l}\text {-Eyes irritation } \\
\text {-Central nervous system depression } \\
\text {-Throat irritation and shortness of } \\
\text { breath }\end{array}$ \\
\hline Alkenes & $\begin{array}{l}\text { Propylene } \\
\text { Ethylene }\end{array}$ & $\begin{array}{l}\text {-Photochemical ozone creativity } \\
\text {-Potentially carcinogenic and } \\
\text { adversely affects the odor and teste } \\
\text { of drinking water }\end{array}$ \\
\hline Polycyclic aromatic hydrocarbons & Phenanthrene & -Carcinogen \\
\hline
\end{tabular}

1

The VOCs separation processes in industrial fields are mainly divided into two parts according to the destruction or recovery of the pollutants, as shown in Figure 1(a): the processes based on destruction including incineration [24 - 28], photocatalytic [29 - 35], catalysts [36 39], oxidation [40 - 43] and biological degradation [44 - 47], and those based on recovery including adsorption [7, 48 - 52], condensation [53, 54], absorption [55 - 60] and membrane processes [61 - 66]. Compared to the destruction processes, the recovery processes are more economic, because it is possible to regenerate both important compounds and value pollutants. Table 2 resumes the advantages and disadvantages of VOCs separation processes.

(a)

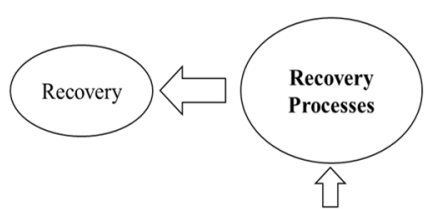

VOCs removing processes

凸

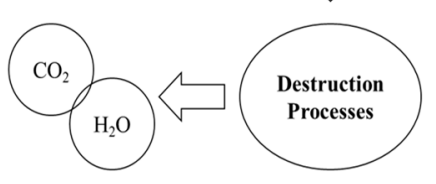

(b)

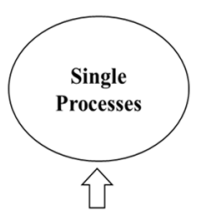

1. Adsorption

2. Absorption

. Cryogenic

Hydrate

Membrane Separation
Condensation

Absorption

Membrane Separation

$\mathrm{CO}_{2}$ separation processes

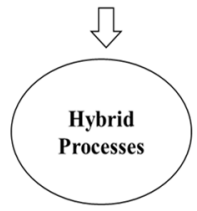

1. Absorption-Adsorption

2. Absorption-Membrane

3. Adsorption-Catalysis

4. Adsorption-Cryogenic

5. Membrane-Cryogenic

6. Membrane-Absorption

Figure 1. Main processes of VOCs (a) and $\mathrm{CO}_{2}$ (b) separation.

Adsorption is economical and environment-friendly, in which a suitable adsorbent is critical. Numerous adsorbents have been studied, such as active carbon [7, 67 - 71], zeolite [72 - 77], polymeric adsorbents [78 - 83], to selectively adsorb VOCs. However, the high cost and the regeneration of adsorbents are the major limitations of adsorption processes. For high concentrations of VOCs, adsorption with a suitable solvent is a commonly method. It is an 
1 undeniable that the spent solvent as the absorber and the disposal of VOCs are the key problems.

2 Condensation processes can be used to remove VOCs but one of major restriction is the disposal

3 of the spent coolants. Because of the energy intensive nature of the process, condensation is

4 limited to only evaporative solvents.

Table 2. Characteristics of VOCs removal processes.

6

\begin{tabular}{|c|c|c|c|c|c|c|c|}
\hline $\begin{array}{c}\text { VOCs } \\
\text { proces } \\
\text { ses }\end{array}$ & Methods & $\begin{array}{c}\text { Waste } \\
\text { generation }\end{array}$ & VOCs & Efficiency & $\begin{array}{c}\text { VOCs } \\
\text { concentrati } \\
\text { on }\end{array}$ & $\begin{array}{c}\text { Advantages (+) } \\
\text { Disadvantages (-) }\end{array}$ & Ref. \\
\hline \multirow{4}{*}{ 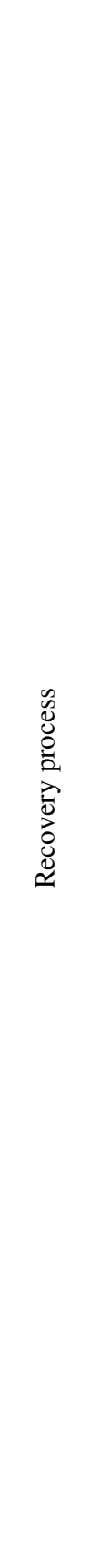 } & Adsorption & $\begin{array}{l}\text { Spent } \\
\text { adsorbent }\end{array}$ & $\begin{array}{l}\text { Benzene } \\
\text { Toluene }\end{array}$ & $>90 \%$ & $\begin{array}{c}\text { 700-1000 } \\
\text { ppm }\end{array}$ & $\begin{array}{l}\text { (+) Fast removal } \\
\text { (+) Recovery of pollutants } \\
\text { (-) Desorption phenomena } \\
\text { during adsorption } \\
\text { process } \\
\text { (-) Competitive } \\
\text { adsorption of other } \\
\text { contaminants }\end{array}$ & [67] \\
\hline & Condensation & - & $\begin{array}{l}\text { Methanol } \\
\text { Methyl- } \\
\text { iso-butyl } \\
\text { ketone }\end{array}$ & - & $\begin{array}{c}>5000 \\
\mathrm{ppm}\end{array}$ & $\begin{array}{l}\text { (+) Recovery of pollutants } \\
\text { (+) Treat high } \\
\text { concentration of } \\
\text { contaminants } \\
\text { (-) High energy } \\
\text { consumption } \\
\text { (-) Low efficacy }\end{array}$ & [84] \\
\hline & Absorption & - & $\begin{array}{l}\text { Toluene } \\
\text { Dimethyl } \\
\text { disulfide }\end{array}$ & - & - & $\begin{array}{l}\text { (+) Fast removal } \\
\text { (-) Gas-liquid absorber } \\
\text { depend on equilibrium } \\
\text { solubility }\end{array}$ & [55] \\
\hline & $\begin{array}{l}\text { Membrane } \\
\text { separation }\end{array}$ & $\begin{array}{l}\text { Clogged } \\
\text { membrane }\end{array}$ & $\begin{array}{l}\text { Dichlorob } \\
\text { enzene }\end{array}$ & $\begin{array}{l}\text { Benzene } \\
\text { Toluene }\end{array}$ & $<25 \%$ & $\begin{array}{l}\text { (+) High efficacy } \\
\text { (+) Treat a wide range of } \\
\text { VOCs } \\
\text { (-) Cleaning requirements } \\
\text { (-) Low concentration of } \\
\text { VOCs is limited } \\
\text { (-) Increasing the pressure } \\
\text { drop results in a greater } \\
\text { mechanical resistance } \\
\text { during operation }\end{array}$ & [66] \\
\hline
\end{tabular}




\begin{tabular}{|c|c|c|c|c|c|c|c|}
\hline \multirow{5}{*}{ 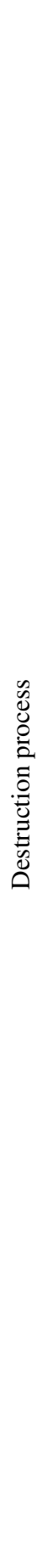 } & Incineration & $\begin{array}{ll}\mathrm{CO}_{2}, & \mathrm{CO}, \\
\mathrm{NO}_{x} & \end{array}$ & - & $\begin{array}{l}>99 \% \\
(40 \mathrm{~min})\end{array}$ & $20 \%-25 \%$ & $\begin{array}{l}\text { (+) Efficient destruction } \\
\text { within short time } \\
\text { (-) High construction cost } \\
\text { (-) Potential formation of } \\
\text { high toxic byproducts }\end{array}$ & {$[25,26]$} \\
\hline & $\begin{array}{c}\text { Photocatalytic } \\
\text { oxidation }\end{array}$ & $\begin{array}{l}\text { Strong } \\
\text { oxidant } \\
\text { OH- } \\
\text { radicals }\end{array}$ & $\begin{array}{l}\text { Toluene } \\
\text { Decane } \\
\text { Trichloroe } \\
\text { thylene }\end{array}$ & $\begin{array}{l}100 \% \\
(5 \mathrm{~min})\end{array}$ & - & $\begin{array}{l}\text { (+) Fast and high efficacy } \\
\text { (-) High energy } \\
\text { consumption } \\
\text { (-) Byproducts formation } \\
\text { (-) Low recovery of } \\
\text { catalysts }\end{array}$ & [86] \\
\hline & $\begin{array}{c}\text { Ozone-catalytic } \\
\text { oxidation }\end{array}$ & $\begin{array}{l}\text { Organic } \\
\text { aerosols }\end{array}$ & $\begin{array}{l}\text { Dichlorob } \\
\text { enzene } \\
\text { Trichlorob } \\
\text { enzene }\end{array}$ & $\begin{array}{l}100 \% \\
(2 \mathrm{~h})\end{array}$ & - & $\begin{array}{l}\text { (+) Effective and fast } \\
\text { removal of contaminants } \\
\text { (-) Low solubility of } \\
\text { ozone in water } \\
\text { (-) Ozone scavengers } \\
\text { commonly found in } \\
\text { environment } \\
\text { (-) Incomplete oxidation }\end{array}$ & {$[86,87]$} \\
\hline & Plasma catalysis & $\begin{array}{l}\text { Carboxylic } \\
\text { acids } \\
\mathrm{NO}_{x} \cdot \\
\mathrm{O}_{3}\end{array}$ & Phenol & $74 \%-81 \%$ & - & $\begin{array}{l}\text { (+) Efficient } \\
\text { (-) Poor energy efficiency } \\
\text { for the treatment of low } \\
\text { VOCs } \\
\text { (-) Formation of } \\
\text { undesirable byproducts }\end{array}$ & [88] \\
\hline & $\begin{array}{l}\text { Biological } \\
\text { degradation }\end{array}$ & $\begin{array}{c}\text { Acetaldehy } \\
\text { de }\end{array}$ & $\begin{array}{l}\text { Formaldeh } \\
\text { yde } \\
\text { Benzene } \\
\text { Toluene } \\
\text { Xylene }\end{array}$ & $\begin{array}{l}100 \% \\
\text { (7 months) }\end{array}$ & $<5000 \mathrm{ppm}$ & $\begin{array}{l}\text { (+) Low cost } \\
\text { (+) In site remediation } \\
\text { (-) Slow kinetics } \\
\text { (-) Inhibitive nature for } \\
\text { local microorganisms }\end{array}$ & [89] \\
\hline
\end{tabular}

In addition, it should not be ignored that the climate change is caused by increasing concentration of $\mathrm{CO}_{2}$ emission. Therefore, it is necessary to develop effective processes for $\mathrm{CO}_{2}$

4 separation. Recently, in order to against global warming, the $\mathrm{CO}_{2}$ separation processes has attracted higher concern. They are mainly divided into two parts according to the numbers of

6 stage processes required to meet the separation targets, as shown in Figure 1(b). 
1 are some disadvantages of each process which restrict their application and development, such 2 as the secondary pollution [90], degradation of solvent [91, 92], high equipment cost [93, 94], 3 and limited selectivity $[95,96]$. To overcome the challenges of single separation process, hybrid processes should be a promising alternative. Combination of different processes can enhance 5 the separation performance and avoid their disadvantages. However, the hybrid process is subject by standalone process. Table 3 summarized the advantages and disadvantages of $\mathrm{CO}_{2}$ separation processes.

Table 3. The advantages and disadvantages of $\mathrm{CO}_{2}$ separation processes [97 - 100].

9

\begin{tabular}{|c|c|c|c|}
\hline \multicolumn{2}{|c|}{$\mathrm{CO}_{2}$ separation processes } & Advantages (+) & Disadvantages (-) \\
\hline \multirow{4}{*}{ 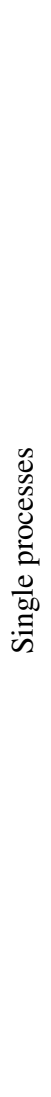 } & Adsorption & $\begin{array}{l}(+) \text { High capacity of } \mathrm{CO}_{2} \text { adsorption } \\
(+) \text { Withstands high-pressure } \\
\text { operation } \\
(+) \text { High selectivity over other gases }\end{array}$ & $\begin{array}{l}\text { (-) High energy consumption } \\
\text { (-) Difficulty of regeneration } \\
\text { (-) Not suitable for cyclic operation }\end{array}$ \\
\hline & Absorption & $\begin{array}{l}\text { (+) Suitable for industrial scales } \\
\text { (+) Operating for low } \mathrm{CO}_{2} \text { feed } \\
\text { concentration }\end{array}$ & $\begin{array}{l}\text { (-) High energy consumption } \\
\text { (-) Corrosion caused by amines degradation } \\
\text { (-) Emissions of harmful by-products } \\
\text { (-) Expensive for regeneration }\end{array}$ \\
\hline & Cryogenic & (+) High product purity & $\begin{array}{l}\text { (-) High energy requirement } \\
\text { (-) Only suitable for high } \mathrm{CO}_{2} \text { feed } \\
\text { concentration (> 50\%) } \\
\text { (-) Need pre-processing step to remove } \\
\text { humidity from mixed feed stream }\end{array}$ \\
\hline & Hydrate & (+) High product purity & $\begin{array}{l}\text { (-) High pressure and low temperature } \\
\text { (-) Cause secondary pollution } \\
\text { (-) High capital cost }\end{array}$ \\
\hline \multirow[t]{2}{*}{ 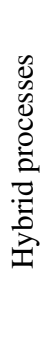 } & Membrane & $\begin{array}{l}\text { (+) Installation easily } \\
\text { (+) Operating simply } \\
\text { (+) Low energy consumption }\end{array}$ & $\begin{array}{l}\text { (-) High surface area of membrane } \\
\text { (-) Humidity of feed gases affect the } \\
\text { permeability, especially polymeric membrane } \\
\text { (-) Performance is affected by operating } \\
\text { conditions }\end{array}$ \\
\hline & & & \\
\hline
\end{tabular}




\begin{tabular}{|c|c|c|}
\hline $\begin{array}{l}\text { Absorption } \\
\text {-Adsorption }\end{array}$ & $\begin{array}{l}(+) \text { Higher } \mathrm{CO}_{2} \text { carrying capacity } \\
(+) \text { Low heat capacity }\end{array}$ & $\begin{array}{l}\text { (-) High sorbent regeneration energy } \\
\text { (-) Emission of harmful by-products } \\
\text { (-) High-pressure drop across the absorber of } \\
\text { small particles }\end{array}$ \\
\hline $\begin{array}{l}\text { Absorption } \\
\text {-Membrane }\end{array}$ & $\begin{array}{l}\text { (+) Low regeneration energy } \\
(+) \text { Low capital cost } \\
(+) \text { Membrane process can reduce } \\
\text { amine emission }\end{array}$ & $\begin{array}{l}\text { (-) Only suitable for relative low } \mathrm{CO}_{2} \text { feed } \\
\text { concentration }(13 \%-23 \%) \\
\text { (-) Corrosion caused by amines degradation }\end{array}$ \\
\hline $\begin{array}{l}\text { Adsorption } \\
\text {-Catalysis }\end{array}$ & $\begin{array}{l}\text { (+) Relative high separation rate } \\
(+) \text { Increasing the conversion of } \mathrm{CO}_{2} \\
(+) \text { Capital cost is reduced } \\
\text { (+) Some absorbents allow two } \\
\text { processes occur in on single } \\
\text { simultaneous }\end{array}$ & $\begin{array}{l}\text { (-) Need pre-processing step to remove } \\
\text { (-) } \mathrm{H}_{2} \text { from mixed feed stream } \\
\text { (-) Need to find a suitable catalyst }\end{array}$ \\
\hline $\begin{array}{l}\text { Adsorption } \\
\text {-Cryogenic }\end{array}$ & (+) Low energy consumption & $\begin{array}{l}\text { (-) Not mature enough to apply in industrial } \\
\text { scales }\end{array}$ \\
\hline $\begin{array}{l}\text { Membrane } \\
\text {-Cryogenic }\end{array}$ & $\begin{array}{l}(+) \text { The size of cryogenic equipment is } \\
\text { reduced } \\
\text { (+) Process efficiency improved } \\
(+) \text { Energy requirement reduced }\end{array}$ & $\begin{array}{l}\text { (-) Need to select a condensing agent } \\
\text { (-) Need future reduce energy consumption }\end{array}$ \\
\hline $\begin{array}{l}\text { Membrane } \\
\text {-Absorption }\end{array}$ & $\begin{array}{l}\text { (+) High purity } \\
(+) \text { High recovery }\end{array}$ & $\begin{array}{l}\text { (-) Need future reduce energy consumption } \\
\text { (-) Only suitable for relative low } \mathrm{CO}_{2} \text { feed } \\
\text { concentration }(15 \%-36 \%)\end{array}$ \\
\hline
\end{tabular}

1

Several $\mathrm{CO}_{2}$ separation processes have been developed in the last decades, for example absorption, adsorption, membrane, cryogenic, and hydrate etc. In the $\mathrm{CO}_{2}$ capture approaches, cryogenic and hydrate are low-temperature processes. Cryogenic process is gases convert into their liquid phase at very low temperatures. Hydrate is a process to form a solid hydrate. Hydrate units are introduced in this process to enhance the hydrate formation and reduce the equilibrium conditions. Low temperature and high pressure are necessary conditions for cryogenic and hydrate [101, 102]. Absorption, and adsorption have been widely applied to many industrial fields and they are relative matured. 
Among all the separation processes, membrane-based separations are deemed as one of the most widely studied and fastest growing separation processes for efficient pollutants treatment [103 - 105]. In order to overcome some disadvantages of membrane-based separation processes and further improvement of their separation performance, researchers are committed to not only optimizing operating parameters but also developing new membrane materials and membrane processes.

Ionic liquids (ILs) are organic molten salts with many excellent properties such as no vapor pressure above the liquid surface, thermal stability, and low volatility [106 - 108]. Within this regard, they have been found uses in a widely range of research fields such as electrolytes [109 - 113], chemical solvents [114 - 117], and catalysts [118, 119]. In addition, they have been successfully applied to several separation processes, such as removing heavy metal ions [120, 121], greenhouse gases treatment [122 - 125], and VOCs removal [1, 126 - 128]. Besides, the most attractive property of ILs is tailor-made, which means IL's properties can be modified via alteration of cations and anions to produce specific compounds for given applications [129, 130]. Therefore, ILs are regarded as effective green solvents alternative to traditional organic solvents. However, several studies have underlined that there are some negative effects of ILs on environment resulting in a limitation of their applications in industry [131 - 133]. It is necessary to find a method to break this limit. Although, it is possible to change the ILs chemical compounds to reduce their environmental risk $[134,135]$. It will increase difficulty to meet the given processes requirements with reduction of their hazard potential. In this case, stability of the ILs into a supported media provides a promising way to realize the use of ILs with environmental damages reducing.

ILs combined with membrane processes have becoming a promising approach in separation fields in recent years. It can promote solvent properties of ILs and enhance membrane separation performances. In the past few years, many different types membrane separation processes containing ILs have been studied, including supported ionic liquid membranes (SILMs), ILs composite polymer membranes (ILPMs), ionic liquids composite mixed matrix membranes (ILMMMs), poly(ionic liquid)s membranes (PILMs), ionic liquid gel membranes (ILGMs), , and ionic liquid membrane contactors (ILMCs). They are mainly focus 
1 on VOCs or $\mathrm{CO}_{2}$ removing. This review firstly provides comprehensive overview on the use of 2 membranes processes with ILs for VOCs or $\mathrm{CO}_{2}$ removal. Moreover, the problems and 3 challenges in ionic liquid membrane separation processes are identified and discussed.

\begin{tabular}{|l|l|l|}
\hline Features & RTILs & Traditional solvents \\
\hline Applicability & Multifunctional & Single functional \\
\hline Chirality & Tunable & Rare \\
\hline Vapor pressure & Negligible & Follow C-Clapeyron equation \\
\hline Flammability & Nonflammable & Flammable \\
\hline Solvation & Strongly solvating & Weakly solvating \\
\hline Polarity & Polarity depends & Conventional polarity \\
\hline Tuneability & Designer solvents & Limited range \\
\hline Recyclability & Economic imperative & Green imperative \\
\hline Viscosity $(\mathrm{cP})$ & $22-40000$ & $0.2-100$ \\
\hline Density $\left(\mathrm{g} \mathrm{cm}^{3}\right)$ & $0.8-3.3$ & $1.3-1.6$ \\
\hline
\end{tabular}

Ionic liquids (ILs) have been got lots of attentions because of their physicochemical properties and potential roles in sustainable development. Specifically, room temperature ionic liquids (RTILs) are salts in liquid at room temperature [136]. The most significant application is RTILs as solvents to replace volatile solvents due to their excellent physicochemical properties. Table 4 exhibits the main difference of features between RTILs and other traditional solvents. This table 4 is given for comparison and the majority of ILs display these properties.

Table 4. Comparison of RTILs and traditional organic solvents [136, 140]

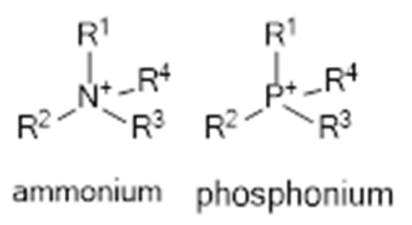

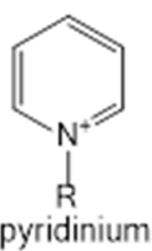<smiles>[R]c1[nH+]ccn1[R]</smiles>

imidazolium

Figure 2. Common organic cations of ILs.

Furthermore, RTILs exist as liquid at ambient temperatures due to their chemical structure. The anion and cation are chosen precisely to destabilize the solid-phase crystal. Therefore, even though there are no set rules to making an IL, this can be achieved within ion structures by balancing ion-ion interactions. Structure and nanostructure control ionic liquid

\section{Physicochemical properties of ionic liquids}


1 properties [137]. Two special types of mesoscale structures exist of in the ILs system. i)

2 hydrogen bond, ii) ionic cluster. The viscosity of IL was effect by hydrogen bond. For example,

3 strength of hydrogen bonds is determined items to improve viscosity of pyridinium ionic liquids

4 [138]. Ionic clustering will influence the IL properties and behaviors including viscosity,

5 dissolution, and acidity or alkalinity [139]. The multiple combinations cation/anion can lead to more than $10^{6}$ different ILs, each of them with specific physicochemical properties. In this case, ILs are also regarded as designer solvents. The cations are generally compositing organic compounds as ammonium, phosponium, pyridinium or imidazolium (Figure 2) with alkyl chains $\left(\mathrm{R}^{\mathrm{n}}\right)$ [142]. The anions of the ILs could be organics or minerals (Table 5). Usually, the physical properties were controlled by cations, and the anions reflect chemical properties [141]. Based on steric hindrance, the cation/anion asymmetry and the alkyl chains length (Table 6) have dramatic effects on the melting point which decrease with that parameters increasing [143, 144]. The low melting point and the thermic stability $\left(>350^{\circ} \mathrm{C}\right)$ allow the use of ILs in a large thermic operating range $\left(300-400^{\circ} \mathrm{C}\right)$. The density of ILs with exception of the tetraalkyborates is generally higher than water. Moreover, the density decreases with the cation alkyl length increasing [145]. In addition, the density is also controlled by the anion. The viscosity of ILs is higher than organic solvents. When the cation alkyl length increase, the viscosity is higher. [146]. ILs are considered as polar solvents and their polarity close to the alcohols with short alkyl length [147]. Generally, the polarity can affect the solubility of ILs. The aromatic compounds are more than ten times the alkyl compounds (Table 7).

Table 5. Common anions of ILs.

\begin{tabular}{|c|c|}
\hline Organic anions & Mineral anions \\
\hline $\mathrm{CH}_{3} \mathrm{CO}_{2}^{-}$ & $\mathrm{X}(=\mathrm{F}, \mathrm{Cl}, \mathrm{Br}, \mathrm{I})$ \\
$\mathrm{OTs}\left(=\mathrm{C}_{6} \mathrm{H}_{5} \mathrm{SO}_{3}^{-}\right)$ & $\mathrm{BF}^{-}, \mathrm{PF}_{6}^{-}$ \\
$\mathrm{NTf}_{2}\left(=\mathrm{N}\left(\mathrm{SO}_{2} \mathrm{CF}_{3}\right)_{2}^{-}\right)$ & Lewis Acid $+\mathrm{X}^{-}$ \\
$\mathrm{OTf}\left(=\mathrm{SO}_{3} \mathrm{CF}_{3}^{-}\right)$ & \\
$\mathrm{CTf}_{3}\left(=\mathrm{C}\left(\mathrm{SO}_{3} \mathrm{CF}_{3}\right)_{3}^{-}\right)$ & \\
\hline
\end{tabular}

Table 6. Effects of ILs characterizes on their properties.

\begin{tabular}{|c|c|c|}
\hline \multicolumn{3}{|c|}{ Effects of the cation/anion asymmetry on the melting point } \\
\hline $\mathrm{X}^{-}$ & $\mathrm{r}(\AA)$ & Melting point $(\mathrm{K})$ \\
\hline
\end{tabular}




\begin{tabular}{|c|c|c|c|c|}
\hline & & & $\mathrm{Na}^{+} \mathrm{X}^{-}$ & $\operatorname{Emim}^{+} \mathrm{X}^{-}$ \\
\hline $\mathrm{Cl}^{-}$ & \multicolumn{2}{|c|}{1.7} & 1074 & 360 \\
\hline $\mathrm{PF}_{6}^{-}$ & \multicolumn{2}{|c|}{2.4} & $>473$ & 333 \\
\hline $\mathrm{AlCl}_{4}^{-}$ & \multicolumn{2}{|c|}{2.8} & 458 & 279 \\
\hline \multicolumn{5}{|c|}{ Alkyl length effects on melting point of the bromide salts } \\
\hline \multicolumn{3}{|c|}{ Cations } & \multicolumn{2}{|c|}{ Melting point $(\mathrm{K})$} \\
\hline \multicolumn{3}{|c|}{$\left[\mathrm{NMe}_{4}\right]^{+}$} & \multicolumn{2}{|c|}{$>573$} \\
\hline \multicolumn{3}{|c|}{$\left[\mathrm{Net}_{4}\right]^{+}$} & \multicolumn{2}{|l|}{557} \\
\hline \multicolumn{3}{|c|}{$\left[\mathrm{NBu}_{4}\right]^{+}$} & \multicolumn{2}{|l|}{399} \\
\hline \multicolumn{3}{|c|}{$\left[\mathrm{NHex}_{4}\right]^{+}$} & \multicolumn{2}{|l|}{373} \\
\hline \multicolumn{3}{|c|}{$\left[\mathrm{NOct}_{4}\right]^{+}$} & \multicolumn{2}{|l|}{368} \\
\hline \multicolumn{5}{|c|}{ Physicochemical values of some ILs } \\
\hline ILs & $\mathrm{M}\left(\mathrm{g} \mathrm{mol}^{-1}\right)$ & $\mathrm{T}(\mathrm{K})$ & Density $\left(\mathrm{g} \mathrm{cm}^{3}\right)$ & Viscosity $(\mathrm{cP})$ \\
\hline$[\mathrm{Bmim}]\left[\mathrm{BF}_{4}\right]$ & 226 & 193 & 1.12 & 233 \\
\hline$[\mathrm{Bmim}]\left[\mathrm{AlCl}_{4}\right]$ & 321 & - & 1.33 & 19 \\
\hline$[\mathrm{Bmim}]\left[\mathrm{NTf}_{2}\right]$ & 419 & 267 & 1.44 & 69 \\
\hline$[\mathrm{Bmim}]\left[\mathrm{PF}_{6}\right]$ & 284 & 265 & 1.37 & 257 \\
\hline$[\mathrm{Bmim}]\left[\mathrm{OP}(\mathrm{O})(\mathrm{OBu})_{2}\right]$ & 348 & - & 1.04 & 1896 \\
\hline$[\mathrm{Mmim}]\left[\mathrm{OP}(\mathrm{OMe})_{2}\right]$ & 222 & - & 1.26 & 363 \\
\hline
\end{tabular}

\section{Membrane processes containing ILs}

ILs are made by associating large organic cations with a wide variety of anions. This results in a large variety of ILs can be adapted to a given process. Combination of these features can bring new opportunities in the use of ILs-membranes and processes in VOCs and $\mathrm{CO}_{2}$ separation applications [148 - 150], which are energy-saving and environmentally-friendly (Figure 3). In recent years, many studies focus on the use of ILs in membranes and membrane processes. The disadvantages of ILs, such as high viscosity, high production costs, unclear toxicities, and potential environment effects [151 - 155], limit their industrial applications. However, consisting of immobilizing ILs into support materials in separation processes, which allows the amount of active phase needed for a given process to be minimized and greatly facilitates the recovery and reusability of ILs. The use of matrix to support ILs enables it to obtain a membrane that serves as a separator between a feeding and a receiving phase. Different types of membrane and membrane processes containing ILs are listed, discussed and compared 
1 in this review, including supported ionic liquid membranes (SILMs), ILs composite polymer membranes (ILPMs), ionic liquids composite mixed matrix membranes (ILMMMs), poly(ionic liquid)s membranes (PILMs), ionic liquid gel membranes (ILGMs), and ionic liquid membrane contactors (ILMCs). For each configuration, advantages and disadvantages are presented and more especially for the treatment of VOCs and $\mathrm{CO}_{2}$ which are the most significant compounds treated.

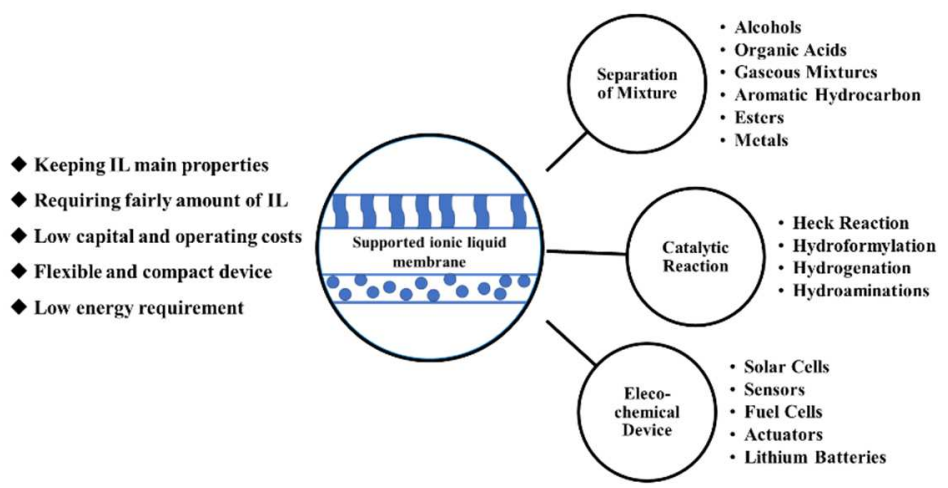

Figure 3. Properties and applications of membrane processes containing ILs for VOCs separations.

\subsection{Supported ionic liquids membranes (SILMs)}

Supported ionic liquid membranes (SILMs) are porous supports which pores are impregnated with ILs [156 - 158]. They have been showing several potentials in different separation applications, such as organic compounds removing $[159,160]$, separation of mixed gases [161 - 163], and vapor permeation [164 - 167]. Generally, the driving force is due to the concentration or pressure gradient between the feed and receiving phase which results in energy conservation $[168,169]$. In addition, high selectivity and low solvent holding of SILMs are also attractive advantages. Whereas, the primary disadvantage is insufficient membrane stability for large scale and long-time operations, which has been proven by several studies [164, 168, 170, 171]. The selectivity of SILMs will decreased strongly because ILs was pushed out of porous support under over-time operation.

For industrial application, the most important property is the process stability. In recently, most researchers focus on improving the stability of SILMs for long-time operation. According to the previous studies, the strategies to improve SILMs stability are mainly from following 
three points: properties of support membrane, viscosity of ILs and preparation ways.

(1)

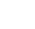

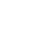

(1)

(1)

(1)
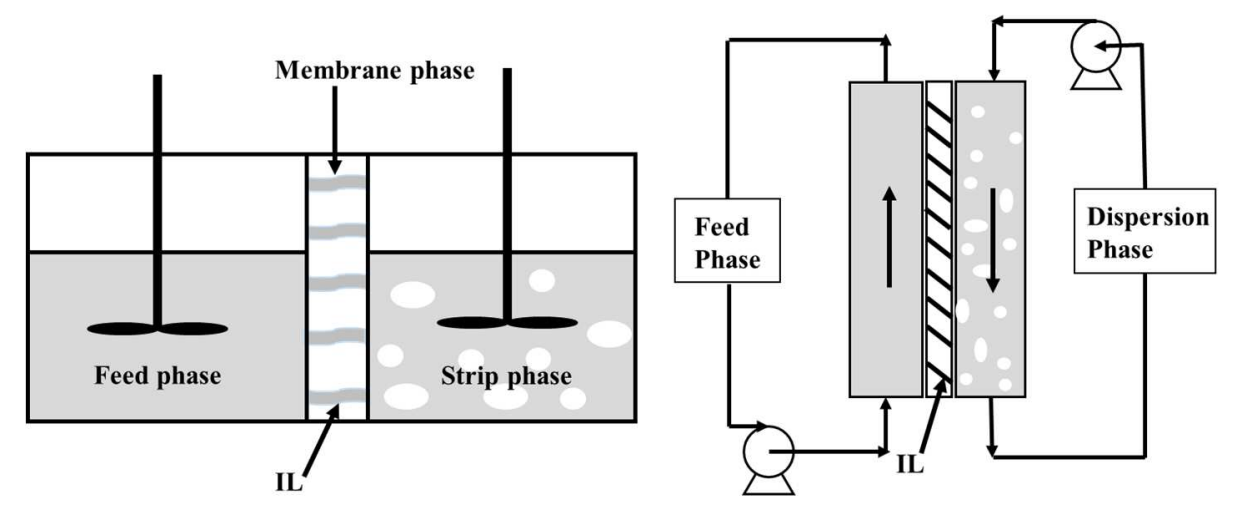

Figure 4. Schematic of SILMs [216]. the support membranes are including inorganic and polymeric membranes. For the inorganic membrane as a support, ceramic membranes are the most widely used due to high mechanical strength and thermal stability. In this case, the SILMs with ceramic membranes as supports can be used at relatively high temperature and pressure of operations. For example, Karousos et al. [172] developed a ceramic membrane with 1-methyl-3-octylimidazolium tricyanomethanide ([Omim][TCM]), which was subjected to a cyclic heating process up to $453 \mathrm{~K}$. Additionally, a thin ionic liquid membrane with a ceramic support that can resist up to 55 bar transmembrane pressure, which was presented by Kreiter et al. [173]. In addition, carbon materials also are a good choice for the inorganic support in SILMs. Chai et al. [174] used a carbon-graphitic carbon nanocomposite membrane to support imidazolium-based RTILs (1-alkyl-3-methylimidazolium bis(trifluoromethylsulfonyl)imide $\left(\left[\mathrm{C}_{\mathrm{n}} \mathrm{mim}\right]\left[\mathrm{TNf}_{2}\right], \mathrm{n}=2,4\right.$, and 6). This supported membrane greatly enhanced the stability of SILMs. The SILMs can operate under transmembrane pressures much higher to $1000 \mathrm{kPa}$ without degrading their separation performances. For the polymeric membrane as a support, Nylon, Polypropylene (PP), Ployvinylidene fluroide (PVDF), polytetrafluoroethylene (PTFE), and Polysulfone (PS) are widely used to prepare SILMs. According to research of Riso et al [175], they studied the Nylon membrane as a support based on three ionic liquids such as 1-butyl-3-methylimidazolium hexafluorophosphate ([Bmim] $\left.]\left[\mathrm{PF}_{6}\right]\right)$, 1-butyl-3-methylimidazolium tetrafluoroborate $\left([\mathrm{Bmim}]\left[\mathrm{BF}_{4}\right]\right)$ and 1-butyl-3methylimidazolium bis(trifluoromethylsulfonyl)imide ([Bmim] $\left.\left[\mathrm{NTf}_{2}\right]\right)$. As shown in Figure 4, the feed and strip phases were separated by an organic membrane phase. They found that the 
mass of ILs retained in membrane pores was constant during operation. CichowskaKopczynska et al. [176] investigated the imidazolium ionic liquids supported on PP. They found that maximum pressure possible to apply without membrane damage was $59 \mathrm{kPa}$. They also revealed that thickness of PP support was higher after swelling ILs, which could change the structure of polymer network and enhance its mechanical stability [177]. The mechanical property of PVDF support on 1-ethyl-3-methylimidazolium ethyl sulfate ([Emim][EtSO $\left.\left.{ }_{4}\right]\right)$ and 1-ethyl-3-mwthylimidazoliun acetate ([Emim][Ac]) were studied by Gomez-Coma et al. [178], and these membranes showed better mechanical properties than others. Moreover, to improve stability of SILMs, PVDF was also used as a support in Kim's study [179]. This SILMs based on 1-n-octyl-3-methylimidazolium hexafluorophosphate $\left(\left[\mathrm{C}_{8} \mathrm{mim}\right]\left[\mathrm{PF}_{6}\right]\right)$ and hydrophobic PVDF, in which the ideal selectivity was improved even after 8 cycles under $298 \mathrm{~K}$ and 1.2 bar [180]. Hanioka et al. [181] examined the long-term stability of a PTFE membrane supported naminopropyl-3-methylimidazolium bis(trifluoromethylsulfonyl)imide ([ $\left.\left.\mathrm{C}_{3} \mathrm{NH}_{2} \operatorname{mim}\right]\left[\mathrm{NTf}_{2}\right]\right)$. They found that membrane kept its permeability and selectivity under atmospheric pressure even after 260 days. Therefore, PS has been used to synthesize support membranes due to excellent mechanical strength, high thermal and chemical stability [182, 183]. Ilconich et al. [184] studied the stability of a SILM with 1-n-hexyl-3-methylimidazolium bis(trifluoromethanesulfonyl)imide ([Hmim][NTf 2$]$ ), and a PS membrane used as a support. They found that membrane was stable up to 398 K. Alkhouzaam et al. [185] synthesized dense SILMs using PS as a support membrane. They investigated the applicability of these SILMs in industrial gas separation processes under high pressure. Respectively, the membrane showed only $30 \%$ and $20 \%$ IL loss with $5 \mathrm{wt} \%$ tributylmethylphosphonium formate ([P 444$][$ formate]) and tributylmethylammonium formate $\left(\left[\mathrm{N}_{444}\right][\right.$ formate $\left.]\right)$ at $10 \mathrm{bar}$ after $12 \mathrm{~h}$. Moreover, there were even not loss of ILs for di-iso-propyl 1-alkyl-3-methylimidazolium bistriflamide ([DIP-

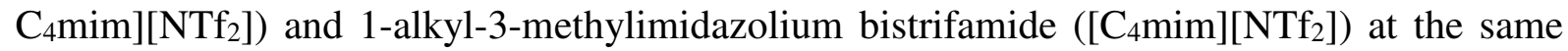
operating conditions.

In addition, the SILMs can tolerate higher transmembrane pressure by choosing a support with suitable pore sizes, because ILs extrusion from the large pores of membrane could be mainly contribute to IL loss of SILMs [186]. Some studies are suggested that supported membranes with pore size range from 100 to $200 \mathrm{~nm}$ are suitable for composed SILMs [168, 
1 186]. Fatyeyeva et al. [187] observed that the presence of ILs influences strongly the permeability of the membrane by reducing the pore sizes. Besides, it should be noted that the high porosity of supports provides more active surface area, which results in a stronger diffusion during the support membrane. However, the mechanical strength of membrane will be decreased with increasing porosity.

Also, different preparation methods of SILMs affect stability. Preparation methods of SILMs fall into three main categories: immersion, vacuum, and pressure. For the immersion, a porous support or substrate is soaked in an IL bath, and then the IL is filled into the pores of the support by capillary forces [168]. This method is the easiest and available way to prepare a SILM. However, the SILMs prepared by this way have less stable. It means the IL within the pores of the supported membrane will be pushed out because of the transmembrane pressure. Fortunato et al. [188] found that immersion method was not suitable for high viscosity of ILs because capillary forces decrease with increasing viscosity of ILs. For the vacuum, IL was spread out the membrane surface by vacuum. Similarly, when the viscosity of ILs increases, the loss of ILs was increased for SILMs prepared by vacuum [189]. This phenomenon can be explained by the fact that ILs are on the external surface of the supported membrane by vacuum method. During operation, it is easy for ILs to break away from the support. For the pressure, IL was forced by certain pressure to get into the pores of supports. This method is suitable for high viscosity of ILs due to independence of ILs. Furthermore, SILMs by pressure method was verified by Hernandez-Fernandez et al. [189]. Recently, the new method cold plasma was used to treat SILMs, they found that the loss of IL by plasma treated was lower than untreated membrane due to the higher affinity of the support and IL [190].

\subsubsection{Separation of VOCs by SILMs}

This process doesn't need high energy consumption due to moderate operation conditions requiring. One the most important application of the SILMs is separate organic compounds selectively. From the study of Matsumoto et al. [1, 192], the selective separation of benzene, toluene, and p-xylene from n-heptane was analyzed using SILMs based on [Bmim] $\left[\mathrm{PF}_{6}\right], 1-$ hexyl-3-methylimidazolium hexafluorophosphate $\left([\mathrm{Hmim}]\left[\mathrm{PF}_{6}\right]\right)$, and 1-methyl-3- 
octylimidazolium hexafluorophosphate $\left([\mathrm{Omim}]\left[\mathrm{PF}_{6}\right]\right)$ supported in a PVDF membrane. It was found that aromatic hydrocarbons were successfully transported through the membrane based on these ionic liquids, the maximum selectivity to n-heptane being reached using benzene in the aromatic permeation and $[\mathrm{Bmim}]\left[\mathrm{PF}_{6}\right]$ in the liquid membrane phase. The feasibility of the prepared SILMs for the separation of water mixed with ethanol or cyclohexane were investigated by Abdellatif Dahi et al. [191]. SILMs were prepared by immobilizing the room temperature ionic liquids (RTILs), 1-butyl-3-methylimidazolium tetrafluoroborate $\left(\left[\mathrm{C}_{4} \mathrm{c}_{1} \mathrm{im}\right]\left[\mathrm{BF}_{4}\right]\right)$ and 1-butyl-3-methylimidazolium hexafluorophosphate $(\mathrm{n}=4)$ and 1-hexyl-3methylimidazolium hexafluorophosphate $(n=6)\left(\left[\mathrm{C}_{n} \mathrm{c}_{1} \mathrm{im}\right]\left[\mathrm{PF}_{6}\right](\mathrm{n}=4\right.$ or 6$\left.)\right)$, in a porous matrimid membrane. For the first study of separating water and VOC vapor, only $\left[\mathrm{C}_{4} \mathrm{c}_{1} \mathrm{im}\right]\left[\mathrm{PF}_{6}\right]$ showed the good sorption. In addition, the SILMs showed satisfactory as well as durability. Tadashi Uragami et al. [193] focused on the addition of hydrophobic ionic liquid 1-allyl-3butylimidazilium bis(trifluoromethylsulfonyl)imide $\quad\left([\mathrm{Abim}]\left[\mathrm{NTf}_{2}\right]\right)$ to poly(methyl methacrylate)-graft-poly(dimethylsioxane) (PMMA-graft-PDMS) membranes for the removal of dilute benzene from an aqueous solution. They found the membrane showed high benzene perm-selectivity and permeability, when the aqueous solution of $0.05 \mathrm{wt} \%$ benzene was permeated. Cichowska-Kopczyriska et al. [176] investigated SILMs for toluene separation from gas phase. The selectivity of toluene/ $\mathrm{N}_{2}$ can reach 306 , which is significantly high. They also performed that permeation of toluene increase with increasing alkyl chain length of bis(trifluoromethylsulfonyl)imide ([TNf 2$])$. From Cichowska-Kopczyriska study [195], the selectivity of SILMs was increased with increasing the alkyl chain length. Furthermore, selectivity of SILMs with a given anion of ILs increased with decreasing the alkyl chain length on the imidazolium ring $[196,197]$. The separation performance of SILMs can be predicted by the relationship between permeability and partition coefficients [198]. Selectivity of SILMs is dependent on the alkyl chain length of ILs.

\subsubsection{Separation of $\mathrm{CO}_{2}$ by SILMs}

$\mathrm{CO}_{2}$ separation processes have become urgent focuses due to global warming and climate change. Recently, the most publications specifically researched on separating $\mathrm{CO}_{2}$ from gas 
1 pairs such as $\mathrm{CO}_{2} / \mathrm{N}_{2}, \mathrm{CO}_{2} / \mathrm{CH}_{4}, \mathrm{CO}_{2} / \mathrm{H}_{2}[199,200], \mathrm{CO}_{2} / \mathrm{SO}_{2}[201,202]$ and $\mathrm{CO}_{2} / \mathrm{He}[184]$.

2 Because the selectivity and permeability are very important, Table 8 and Table 9 show the

3 different SILMs performance on separation of $\mathrm{CO}_{2} / \mathrm{N}_{2}$ and $\mathrm{CO}_{2} / \mathrm{CH}_{4}$.

For the separation of $\mathrm{CO}_{2}$ from $\mathrm{CO}_{2} / \mathrm{N}_{2}$ gas pair. Lee et al. [203] added $\mathrm{CrO}_{3}$ particles into a SILMs composited by $[\mathrm{Bmim}]\left[\mathrm{BF}_{4}\right]$ and polyethylene oxide (PEO) support. They found that the selectivity and the permeance of $\mathrm{CO}_{2}$ from $\mathrm{CO}_{2} / \mathrm{N}_{2}$ were enhanced. The maximum permeance and selectivity of composite membrane were 144 GPU and 30. Schott et al. [204] researched the $\mathrm{CO}_{2}$ solubility in several larger cyclic skeleton ILs. They suggested that amino functionality of basic ILs compounds are highly affected on $\mathrm{CO}_{2}$ solubility. The maximum selectivity $\mathrm{CO}_{2}$ can reach 53 by $[\operatorname{Emim}]\left[\mathrm{B}(\mathrm{CN})_{4}\right]$ and highest solubility is $0.13 \mathrm{~mol} \mathrm{~L}^{-1} \mathrm{~atm}^{-1}$ at $298 \mathrm{~K}$ by $[\mathrm{EtDBN}]\left[\mathrm{TNf}_{2}\right]$. The larger $\mathrm{CO}_{2}$ solubility was attributed to electrostatic interactions or binding energy decreasing between the cation and anion in ILs. Grunaure et al. [205] compared the selectivity and permeability of $\mathrm{CO}_{2}$ from $\mathrm{CO}_{2} / \mathrm{N}_{2}$ on SILMs with three different ILs including 1-ethyl-3-methylimidazolium dicyanoamide ([Emim][DCA]), 1-ethyl-3methylimidazolium bis(trifluoromethylsulfonyl)imide ([Emim] $\left.\left[\mathrm{NTf}_{2}\right]\right)$, and $[\mathrm{Bmim}]\left[\mathrm{PF}_{6}\right]$. The results showed that [Emim][DCA] performed best in selectivity of $\mathrm{CO}_{2}$ reach 65 , and the highest permeability was from $[\mathrm{Emim}]\left[\mathrm{NTf}_{2}\right]$. For the high selectivity, $\mathrm{CO}_{2}$ showed high affinity to [Emim][DCA] due to highly delocalized anions of IL [206], and low $\mathrm{N}_{2}$ bonding [207]. For the high permeability, it is mainly because of the flexible structure and $\mathrm{CF}_{3}$ groups of $\mathrm{TNf}_{2}$, which permit fast throughput [208]. Yahia et al. [209] described a new method for SILMs to enhance the selective $\mathrm{CO}_{2}$ at high temperature. They presented good permeability (733 barrer) at high temperature $(373 \mathrm{~K})$, and transport selectivity of $\mathrm{CO}_{2}$ was 35.6 from $\mathrm{CO}_{2} / \mathrm{N}_{2}$. Fan et al. [210] design a SILMs with (2-hydroxyethyl)-trimethyl-ammonium(S)-2pyrrolidinecarboxylic ([Choline][Pro]) and polyethylene glycol 200 (PEG 200). When the weight ration of [Choline][Pro] to PEG 200 was $1: 2$, the permeability of $\mathrm{CO}_{2}$ from $\mathrm{CO}_{2} / \mathrm{N}_{2}$ reached to 1798.6 barrer at $343.15 \mathrm{~K}$, while the selectivity of $\mathrm{CO}_{2}$ was decreased to 7.9 under same operating conditions. 
Table 8. Gas permeability and selectivity for $\mathrm{CO}_{2}$ and $\mathrm{N}_{2}$ through SILMs.

\begin{tabular}{|c|c|c|c|c|c|c|c|}
\hline \multirow{2}{*}{ ILs } & \multirow{2}{*}{ Supports } & \multirow{2}{*}{$\begin{array}{c}\text { Temperature } \\
\mathrm{K}\end{array}$} & \multirow{2}{*}{$\begin{array}{c}\text { Pressure } \\
\text { bar }\end{array}$} & \multicolumn{2}{|c|}{ Permeability (barrers) } & \multirow{2}{*}{ Selectivity } & \multirow{2}{*}{ Ref. } \\
\hline & & & & $\mathrm{CO}_{2}$ & $\mathrm{~N}_{2}$ & & \\
\hline$[\mathrm{MeDBU}]\left[\mathrm{B}(\mathrm{CN})_{4}\right]$ & \multirow{3}{*}{$\begin{array}{l}\text { Polyether } \\
\text { sulfone }\end{array}$} & \multirow{3}{*}{298} & \multirow{3}{*}{1} & 834 & 17 & 49 & \multirow{3}{*}[204]{} \\
\hline$[\mathrm{EtDBU}]\left[\mathrm{B}(\mathrm{CN})_{4}\right]$ & & & & 672 & 14 & 48 & \\
\hline$[\mathrm{EtDBU}]\left[\mathrm{NTf}_{2}\right]$ & & & & 432 & 16 & 26 & \\
\hline [Emim][DCA] & \multirow{3}{*}{ PS-b-P4VP } & \multirow{3}{*}{303} & \multirow{3}{*}{-} & 480 & 7.4 & 65 & \multirow{3}{*}{ [205] } \\
\hline$[$ Emim $]\left[\mathrm{NTf}_{2}\right]$ & & & & 120 & 10 & 12 & \\
\hline$[\mathrm{Bmim}][\mathrm{Ac}]$ & & & & 100 & 6.7 & 15 & \\
\hline$\left[\mathrm{C}_{4} \mathrm{mim}\right]\left[\mathrm{NTf}_{2}\right]$ & PVDF & 373 & 0.7 & 733.7 & 20.6 & 35.6 & [209] \\
\hline$[$ AEmim $]\left[\mathrm{NTf}_{2}\right]$ & \multirow{3}{*}{ Ceramic } & \multirow{3}{*}{303} & \multirow{3}{*}{0.78} & - & - & 13 & \multirow{3}{*}{ [211] } \\
\hline$[\mathrm{AEmim}]\left[\mathrm{BF}_{4}\right]$ & & & & - & - & 2 & \\
\hline [Toma][An] & & & & - & - & 70 & \\
\hline$[\mathrm{Emim}][\mathrm{Ac}]$ & Ceramic & 303 & 2 & - & - & 34.7 & {$[212]$} \\
\hline$[\mathrm{Bmim}]\left[\mathrm{NTf}_{2}\right]$ & \multirow{2}{*}{ Ceramic } & \multirow{2}{*}{303} & \multirow{2}{*}{2} & - & - & 127 & \multirow{2}{*}{ [213] } \\
\hline$\left[\mathrm{C}_{8} \mathrm{~F}_{13} \mathrm{mim}\right]\left[\mathrm{NTf}_{2}\right]$ & & & & - & - & 72 & \\
\hline$\left[\right.$ Emim] $\left[\mathrm{NTf}_{2}\right]$ & Ceramic & 303 & 2 & - & - & 21 & {$[186]$} \\
\hline$[\mathrm{Bz} P y]\left[\mathrm{NTf}_{2}\right]$ & \multirow{4}{*}{ PTEF } & \multirow{4}{*}{298} & \multirow{4}{*}{0.35} & 518 & 18.4 & 27.9 & \multirow{4}{*}{ [214] } \\
\hline$\left[\mathrm{Bz}_{2} \mathrm{Py}\right]\left[\mathrm{NTf}_{2}\right]$ & & & & 358 & 10.8 & 33.1 & \\
\hline$\left[\mathrm{Bz}_{3} \mathrm{Py}\right]\left[\mathrm{NTf}_{2}\right]$ & & & & 446 & 20.3 & 22 & \\
\hline$[\mathrm{Bz} 4 \mathrm{Py}]\left[\mathrm{NTf}_{2}\right]$ & & & & 496 & 21.9 & 22.6 & \\
\hline $\begin{array}{l}\text { [Choline][Pro] } \\
50 \mathrm{wt} \%\end{array}$ & PEG200 & 308 & 1.8 & 343.3 & 9.9 & 34.8 & {$[210]$} \\
\hline [DMAPH][EoAc] & \multirow{2}{*}{ PES } & \multirow{2}{*}{313} & \multirow{2}{*}{ - } & 3028 & 20 & 151.4 & \multirow{2}{*}{ [215] } \\
\hline [DMAPH][TFA] & & & & 3352 & 26 & 129 & \\
\hline
\end{tabular}

3 For the separation of $\mathrm{CO}_{2}$ from $\mathrm{CO}_{2} / \mathrm{CH}_{4}$ gas pair. Bara et al. [194] synthesized three

4 molten salts with increasing lengths of fluoroalkyl substituents for SILMs and tested their gas

5 separation properties. The results exhibited that ideal selectivity for $\mathrm{CO}_{2} / \mathrm{CH}_{4}$ separating was

6 higher than $\mathrm{CO}_{2} / \mathrm{N}_{2}$. Zhang et al. [216] studied 1-buthyl-3-methylimidazolium acetate

7 ([Bmim] $[\mathrm{Ac}])$ supported by PVDF selected separation of $\mathrm{CO}_{2}$. The results showed high

8 permeability $\mathrm{CO}_{2}$ (2148 barrer) and perm-selectivity of $\mathrm{CO}_{2} / \mathrm{CH}_{4}(40)$ under 1 bar and $313 \mathrm{~K}$.

9 In addition, Zhang's group increased the $\mathrm{CO}_{2}$ selective separation furtherly [215]. In this membrane, they used PES supported [DMAPH][EoAc] to separate $\mathrm{CO}_{2}$ from $\mathrm{CO}_{2} / \mathrm{CH}_{4}$. The

11 highest permeability was 3028 barrer and perm-selective reached to 72 from $\mathrm{CO}_{2} / \mathrm{CH}_{4}$ and 151

12 from $\mathrm{CO}_{2} / \mathrm{N}_{2}$. Liu et al. [217] used RTIL [Tespmim] $\left[\mathrm{BF}_{4}\right]$ modified a membrane tested the $\mathrm{CO}_{2}$ 
1 permeances and selectivity of original and modified. They found that the selectivity of $\mathrm{CO}_{2}$ of

2 the modified membrane was enhanced. Moreover, ideal $\mathrm{CO}_{2}$ selectivity of original membrane

3 was 17 , and increased to 76 for modified membrane with the same operating conditions. While,

4 the $\mathrm{CO}_{2}$ permeance of modified membrane decreased by $44 \%$. One important phenomenon

5 observed in several researches was a trade-off process. It means the selectivity decreases, when

6 having high permeability [218].

Table 9. Gas permeability and selectivity for $\mathrm{CO}_{2}$ and $\mathrm{CH}_{4}$ through SILMs.

\begin{tabular}{|c|c|c|c|c|c|c|c|}
\hline \multirow{2}{*}{ ILs } & \multirow{2}{*}{ Supports } & \multirow{2}{*}{$\begin{array}{l}\mathrm{T} \\
\mathrm{K}\end{array}$} & \multirow{2}{*}{$\begin{array}{c}\mathrm{P} \\
\text { bar }\end{array}$} & \multicolumn{2}{|c|}{ Permeability (barrer) } & \multirow{2}{*}{ Selectivity } & \multirow{2}{*}{ Ref. } \\
\hline & & & & $\mathrm{CO}_{2}$ & $\mathrm{CH}_{4}$ & & \\
\hline$[\mathrm{Bmim}]\left[\mathrm{PF}_{6}\right]$ & \multirow{5}{*}{ PVDF } & \multirow{5}{*}{313} & \multirow{4}{*}{0.1} & 512 & 63.9 & 8 & \multirow{5}{*}{ [216] } \\
\hline$[\mathrm{Bmim}]\left[\mathrm{BF}_{4}\right]$ & & & & 1104 & 111 & 9.9 & \\
\hline$[\mathrm{Bmim}]\left[\mathrm{NTf}_{2}\right]$ & & & & 1233 & 131 & 9.4 & \\
\hline [Bmim][OTf] & & & & 1078 & 84.8 & 12.7 & \\
\hline$[\mathrm{Bmim}][\mathrm{Ac}]$ & & & 1 & 2148 & 53.6 & 40 & \\
\hline CPTES & \multirow{2}{*}{ zeolite } & \multirow{2}{*}{298} & \multirow{2}{*}{2} & - & - & 26 & \multirow{2}{*}{ [217] } \\
\hline$[$ Tespmim $]\left[\mathrm{BF}_{4}\right]$ & & & & - & - & 87 & \\
\hline [APTMS][Ac] & $\mathrm{P}-84$ & 298 & 10 & - & - & 38.1 & [218] \\
\hline [DMAPH][TFA] & \multirow{2}{*}{ PES } & \multirow{2}{*}{303} & & 3352 & 50 & 67 & \multirow{2}{*}{ [215] } \\
\hline [DMAPH] [EoAc] & & & & 3028 & 42 & 72 & \\
\hline$\left[\mathrm{P}_{66614}\right][\mathrm{Cl}]$ & PES & 298 & 0.2 & 350 & 89 & 3.9 & [219] \\
\hline$\left[\mathrm{C}_{2} \mathrm{mim}\right]\left[\mathrm{NTf}_{2}\right]_{0.75}[\mathrm{Ac}]_{0.25}$ & PVDF & 293 & 1 & 503 & 16 & 31.4 & [219] \\
\hline$\left[\mathrm{N}_{2224}\right]_{2}[$ maleate $]$ & PES & 313 & 0.1 & 2840 & 13 & 218.5 & [201] \\
\hline$\left[\mathrm{C}_{3} \mathrm{NH}_{2} \operatorname{mim}\right][\mathrm{OTf}]$ & PTFE & 298 & 0.025 & 2600 & 21 & 123.8 & [181] \\
\hline$\left[\mathrm{P}_{4441}\right][$ formate $] 5 \mathrm{wt} \%$ & \multirow{8}{*}{ PSF } & \multirow{8}{*}{295} & \multirow{8}{*}{10} & 11.5 & 0.4 & 32 & \multirow{8}{*}{ [185] } \\
\hline$\left[\mathrm{P}_{4441}\right][$ formate $] 25 \mathrm{wt} \%$ & & & & 17.3 & 0.48 & 31 & \\
\hline$[\mathrm{DIPc} 4 \mathrm{mim}]\left[\mathrm{NTf}_{2}\right] 0.5 \mathrm{wt} \%$ & & & & 12.2 & 0.19 & 61 & \\
\hline$[\mathrm{DIPc} 4 \mathrm{mim}]\left[\mathrm{NTf}_{2}\right] 2.5 \mathrm{wt} \%$ & & & & 13.8 & 0.22 & 63 & \\
\hline$\left[\mathrm{C}_{4} \mathrm{mim}\right]\left[\mathrm{NTf}_{2}\right] 0.5 \mathrm{wt} \%$ & & & & 10.9 & 0.19 & 57 & \\
\hline$\left.\left[\mathrm{C}_{4} \mathrm{mim}\right]\left[\mathrm{NTf}_{2}\right]\right] 2.5 \mathrm{wt} \%$ & & & & 11.5 & 0.16 & 70 & \\
\hline$\left[\mathrm{N}_{4441}\right][$ formate] $0.5 \mathrm{wt} \%$ & & & & 12.5 & 0.26 & 47 & \\
\hline$\left[\mathrm{N}_{4441}\right][$ formate $] 2.5 \mathrm{wt} \%$ & & & & 10.2 & 0.22 & 46 & \\
\hline $\operatorname{Pr}[\operatorname{mim}]_{2}\left[\mathrm{NTf}_{2}\right]$ & \multirow{3}{*}{ alumina } & \multirow{3}{*}{300} & \multirow{3}{*}{0.3} & 190 & 7 & 27.1 & \multirow{3}{*}{ [219] } \\
\hline $\mathrm{h}[\operatorname{mim}]_{2}\left[\mathrm{NTf}_{2}\right]$ & & & & 230 & 14 & 16.4 & \\
\hline$[\mathrm{Hmim}]\left[\mathrm{NTf}_{2}\right]$ & & & & 1101 & 31.5 & 31.5 & \\
\hline
\end{tabular}

9 Generally, the selectivity and permeability of $\mathrm{CO}_{2}$ through SILMs are mainly influenced by 10 properties and structures of ionic liquids, gas pair, supports, and operating conditions. The 11 effects from structures and properties of ILs are studied. Usually, modified or synthesized ILs 
can increase the $\mathrm{CO}_{2}$ solubility based on synergistic effect between $\mathrm{CO}_{2}$ and the IL [217]. For example, adding inorganic particles into ILs [203,212] or using different types of precursors to synthesize ILs [219]. For example, $\mathrm{CO}_{2}$ have high affinity to delocalized anions [220] and -CN group [205]. ILs containing acetate [205] and amine [213, 221] functional groups can increase the $\mathrm{CO}_{2}$ solubility or promote reactions to capture $\mathrm{CO}_{2}$. This method is also limited by the gas pair. The viscosity and molar volume of ILs are important parameters for selectivity and permeability of $\mathrm{CO}_{2}$. The higher viscosity leads to a lower diffusivity of $\mathrm{CO}_{2}$ and permeability [209]. Camper et al. [208] and Shannon et al. [214] showed the solubility and selectivity of gas affected by molar volume, and they also gave a method to estimate gas permeability and selectivity for ideal $\mathrm{CO}_{2} / \mathrm{N}_{2}$ and $\mathrm{CO}_{2} / \mathrm{CH}_{4}$. Ilyas [218] suggested that their SILMs which showed high selectivity for $\mathrm{CO}_{2} / \mathrm{CH}_{4}$ can be attributed to the high solubility of $\mathrm{CO}_{2}$ in the selected IL as well as its molar volume. The selectivity and permeability of $\mathrm{CO}_{2}$ not only depend on the selected IL but also on the porous support including effective pore size and surface porosity. The ideal selectivity was found to be independent of supported membrane pore size [186]. However, it is opposite for permeance. Close at al. [186] found the permeance value of supported membrane with larger pore size was higher than small pore size. It is value to note for polymeric supported membrane, the effective pore size diameter was reduced due to in the presence of water [221], resulting a change of selectivity and permeability. It can be stated that the higher porosity results directly in higher permeability of $\mathrm{CO}_{2}$ by comparing the membranes with different porous structures. Finally, the operating conditions such as temperature and pressure are also significant. The selectivity was decreased with increasing temperature [217, 218]. In addition, when the pressure increase, selectivity was decreased [185].

\subsection{IL-Polymer membranes (ILPMs)}

ILs composite polymer membranes provide a successful method to solve the instability of SILMs [225]. The IL was stabilized into a polymeric membrane by entrapped it in the space of polymer chains or clusters [226, 227], which provides a mechanically stable membrane as shown in Figure 4. 
1

2

3

4

5

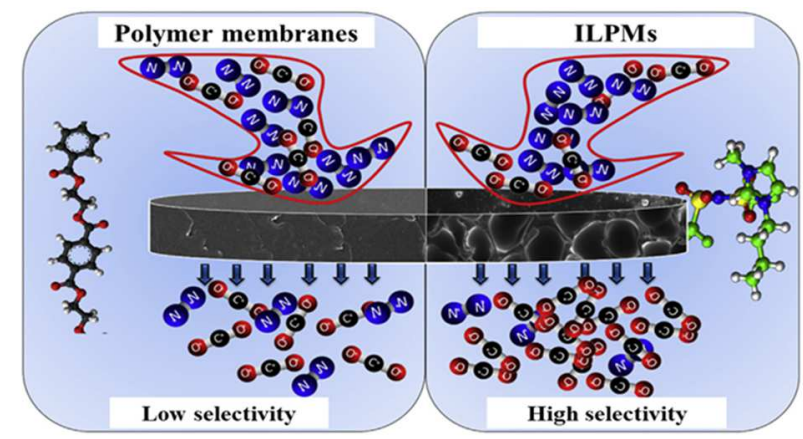

Figure 5. Schematic of polymer membranes and ILPMs [259].

Although, polymeric membranes exhibited excellent mechanical stability, which can overcome the main drawback of SILMs, it should be noted that PILMs already show a certain trade-off between permeability and selectivity for gas separation [218]. Therefore, several researches were donated to find a solution to reduce the trade-off and to develop a desirable membrane.

According to previous studies, the IL loading content and polymeric membranes affect the stability of ILPMs [228, 229]. Mass transfer in ILs is much faster than in a solid polymeric matrix, resulting higher gas flux and faster separation for ILPMs with higher IL loading [227]. For example, $\mathrm{CO}_{2}$ permeability increased from 400 to 1800 barrer when the 1-ethyl-3methylimidazolium tetracyanoborate $\left(\left[\mathrm{C}_{2} \mathrm{mim}\right][\mathrm{TCB}]\right)$ loading from 0 to $75 \mathrm{vol} \%$ to a PVDF matrix [230]. In addition, they observed that polymer matrix be more amorphous with the increase of ILs content which supports the enhance the permeability of gas species through polymers. Furthermore, the stability of polymeric matrix directly determines the operating pressure and temperature of the ILPMs. For example, Mannan et al. [231] synthesized the [Emim] $\left[\mathrm{NTf}_{2}\right](50 \%)$ and PES composite membrane. This ILPM displayed great stability at a trans-membrane pressure up to 25 bar. It not observed plasticization phenomena on their membrane even under such high operating pressure. Kim et al. [179] found that the ILPMs membrane composited by $40 \%$ of 1-ethyl-3-methylimidazolium tetrafluoroborate $\left(\left[\mathrm{C}_{2} \mathrm{mim}\right]\left[\mathrm{BF}_{4}\right]\right)$ and PVDF-HFP showed high temperature resistance up to $673 \mathrm{~K}$. In conclusion, the polymer host matrix was selected based on high mechanical strength, high thermal and chemical stability, and the IL was selected in ILPM mainly based on its high affinity of $\mathrm{CO}_{2}$ and less viscosity [232]. 


\subsubsection{Separation of VOCs by ILPMs}

PILMs have caused wide public concern over the recent years for VOCs separating. Tadashi Uragami et al. [233] studied the removal of chloroform, benzene and toluene from aqueous solutions of dilute VOCs by poly(styrene)-b-poly(dimethylsiloxane) (PSt-b-PDMS) membranes containing [Abim] $\left[\mathrm{NTf}_{2}\right]$ (loading content from 0 to $30 \mathrm{wt} \%$ ). The results showed that strong VOC/water selectivity when aqueous solutions of $0.05 \mathrm{wt} \%$ VOCs. [Abim][ $\mathrm{NTf}_{2}$ ] localized in the PSt-b-PDMS membrane acts as an absorbent to selectivity partition VOCs from the aqueous solution. Both the permeability and the VOCs perm-selectivity of ILPMs were promoted due to the affinity of IL and VOCs. Furthermore, they used the same IL with another polymeric matrix composited a new ILPM. The poly(methyl metracrelate)-gpoly(dimethylsiloxane) (PSMMA-g-PDMS) membranes containing [Abim][ $\mathrm{NTf}_{2}$ ] (loading content including $10 \mathrm{wt} \%, 15 \mathrm{wt} \%$, and $20 \mathrm{wt} \%$ ) showed high benzene selectivity from an aqueous solution. The permeability and the benzene selectivity were enhanced with increasing the IL content [193]. When the IL content increased, the solubility of VOCs in membrane was increased because of the preferential absorption of VOCs in membrane and the high diffusivity of VOCs in the polymer matrix with IL. The imidazolium-based ILs (1-n-althyl-3methylimidazolium tetrafluorobrate, $\mathrm{n}=4,6-8,12)$ and PVDF membranes were used to characterize ethanol and cyclohexane vapor sorption performance [187]. It was revealed increasing the sorption capacity with increasing alkyl chain length because of the enhancement of ability of interaction via van der waals interactions [234 - 236]. Jebur et al. [237] composited imidazolium based ionic liquids and hydrophobic PTFE based membrane to separate aromatic compounds from non-aqueous medium. They found the order of separation efficiency was divinylbenzene $>$ styrene $>$ toluene due to affinities with the IL. Moreover, the stability of this membrane was evaluated up to 60 days. More other applications of PILMs to remove VOCs are shown in Table 10. Briefly, the performance of ILPMs in the separation processes of VOCs is mainly dependents on two factors $[238,239]$ : i) polymeric membrane parameters, including thickness, pore size, and hydrophilicity; ii) properties and content of ILs. 
Table 10. Summary of the applications of ILPMs on VOCs removal.

2

\begin{tabular}{|c|c|c|c|c|c|}
\hline ILs & Polymers & VOCs & Conditions & Major inclusions & Ref \\
\hline $\begin{array}{c}{[\mathrm{Bmim}]\left[\mathrm{PF}_{6}\right]} \\
{[\mathrm{Hmim}]\left[\mathrm{PF}_{6}\right]} \\
{[\mathrm{Omim}]\left[\mathrm{PF}_{6}\right]} \\
{\left[\mathrm{Et}_{2} \mathrm{MeMeON}\right]\left[\mathrm{NTf}_{2}\right]}\end{array}$ & $\begin{array}{c}\text { polyvinyliden } \\
\text { e } \\
\text { (PVDF) }\end{array}$ & $\begin{array}{l}\text { benzene } \\
\text { toluene } \\
\text { p-xylene }\end{array}$ & $\begin{array}{l}\text { - effective area: } 20 \mathrm{~cm}^{2} \\
\text { - pore size of PVDF film: } \\
45 \mathrm{um} \\
\text { - feed solutions: } \\
\text { mixed of heptane and } \\
\text { aromatic hydrocarbon } \\
\text { - receiving solution: } \\
\text { hexadecane } \\
\text { - room temperature }\end{array}$ & $\begin{array}{l}\text { The permeation rate of } \\
\text { hydrocarbon } \\
\text {-based on ILs: } \\
\text { heptane>toluene>p- } \\
\text { xylene>benzene } \\
\text {-based on water: } \\
\text { Toluene } \leq \text { heptane < benzene < } \\
\text { p-xylene }\end{array}$ & [240] \\
\hline $\begin{array}{l}{\left[\mathrm{C}_{4} \mathrm{mim}\right]\left[\mathrm{PF}_{6}\right]} \\
{\left[\mathrm{C}_{6} \mathrm{mim}\right]\left[\mathrm{PF}_{6}\right]} \\
{\left[\mathrm{C}_{8} \mathrm{mim}\right]\left[\mathrm{PF}_{6}\right]}\end{array}$ & $\begin{array}{l}\text { elcosene } \\
\text { copolymer } \\
\text { (VP) }\end{array}$ & $\begin{array}{c}\text { benzene } \\
\text { cyclohexane }\end{array}$ & $\begin{array}{l}\text {-effective area: } 38.4 \mathrm{~cm}^{2} \\
\text {-feed solutions: } \\
\text { benzene cyclohexane } \\
\text {-sweep stream: } \\
50 \mathrm{~mL} \mathrm{~min}{ }^{-1} \\
\text {-temperature: } 303 \mathrm{~K}\end{array}$ & $\begin{array}{l}\text {-benzene selectively permeated } \\
\text { the membrane } \\
\text {-permeability was mainly } \\
\text { controlled in the membrane by } \\
\text { diffusivity } \\
\text {-the separation factor increased } \\
\text { as the hydrophilicity of ILs } \\
\text { increased }\end{array}$ & [241] \\
\hline [Abim][TFSI] & $\begin{array}{l}\text { poly(methyl } \\
\text { methacrylate) } \\
\text {-graft- } \\
\text { poly(dimethyl } \\
\text { siloxane) } \\
\text { (PMMA-g- } \\
\text { PDMS) }\end{array}$ & benzene & $\begin{array}{l}\text {-feed solution: } \\
0.05 \mathrm{wt} \% \text { and water } \\
\text {-temperature: } 313 \mathrm{~K}\end{array}$ & $\begin{array}{l}\text {-PMMA-g-PDMS increased } \\
\text { benzene-permselectivity with } \\
\text { increasing DMS content } \\
\text {-introducing molecular } \\
\text { recognition into membrane } \\
\text { matrix can improve } \\
\text { permeability for removing } \\
\text { benzene }\end{array}$ & [193] \\
\hline [Abim][TFSI] & $\begin{array}{l}\text { poly(styrene)- } \\
\text { b- } \\
\text { poly(dimethyl } \\
\text { siloxane) }\end{array}$ & $\begin{array}{l}\text { benzene } \\
\text { chloroform } \\
\text { toluene }\end{array}$ & $\begin{array}{l}\text {-feed solution: } \\
0.05 \text { wt\% VOCs mix water } \\
\text {-pressure: } 1.33 \mathrm{~Pa} \\
\text {-Temperature: } 313 \mathrm{~K} \\
\text {-effective area: } 13.8 \mathrm{~cm}^{2}\end{array}$ & $\begin{array}{l}\text {-the permeability of VOC and } \\
\text { perm-selectivity were enhanced } \\
\text { on increasing the ILs content } \\
\text {-introduction of ILs to } \\
\text { membrane increased the } \\
\text { solubility of VOCs into the } \\
\text { membrane }\end{array}$ & [233] \\
\hline
\end{tabular}




\begin{tabular}{|c|c|c|c|c|c|}
\hline [Abim][TFSI] & $\begin{array}{l}\text { poly(vinyl } \\
\text { chloride) } \\
\text { (PVC) }\end{array}$ & benzene & $\begin{array}{l}\text {-feed solution: } \\
0.05 \mathrm{wt} \% \text { mix aqueous } \\
\text { solution }\end{array}$ & $\begin{array}{l}\text {-the addition of IL into PVC } \\
\text { membrane enhanced both the } \\
\text { permeability and benzene/water } \\
\text { selectivity } \\
\text {-the sorption selectivity } \\
\text { increased by adding IL into } \\
\text { PVC membrane }\end{array}$ & [242] \\
\hline$\left[\mathrm{C}_{2} \operatorname{mim}\right]\left[\mathrm{Tf}_{2} \mathrm{~N}\right]$ & $\begin{array}{l}\text { poly(vinylide } \\
\text { nce fluoride- } \\
\text { co- } \\
\text { hexgluroprop } \\
\text { ylene) } \\
\text { P(PDF-HFP) }\end{array}$ & $\begin{array}{l}\text { n-hexane } \\
\text { isooctane }\end{array}$ & 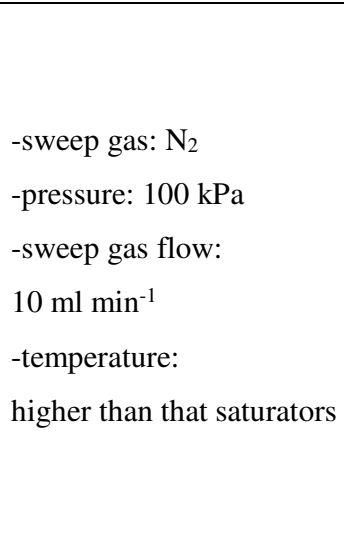 & $\begin{array}{l}\text {-the vapour sorption and } \\
\text { transport properties were } \\
\text { enhanced when membrane } \\
\text { containing } 80 \text { mass\% of IL } \\
\text { - with the temperature range of } \\
298-318 \mathrm{~K} \text {, the permeability of } \\
\text { hexane and of isooctane were } \\
\text { found to be independent of both } \\
\text { temperature and activity of the } \\
\text { permeant }\end{array}$ & [243] \\
\hline
\end{tabular}

Blending a task-specific IL with proper polymer membrane could provide remarkable selectivity for $\mathrm{CO}_{2}$. In this case, choosing a proper polymer membrane is very important. For gas separation, membranes prepared from glassy polymers have been widely studies, including PIM-1 [258], cellulose acetate (AC) [244, 245], polysulfone (PSF) [183, 246], Nafion [253] and polyimides (PI) [247, 248]. However, these polymer membranes show low gas permeability and high gas selectivity even at high operating pressure due to low free volume [249]. In addition, membranes prepared from rubbery polymers, such as poly(ethylene oxide) (PEO) [250], poly(amide-6-b-ethylene oxide) (Pebax) [251], poly(dimethyl siloxane) (PDMS) [252], and Nylon [254], show excellent permeability because of the strong chemical affinity between polymer chains and gas molecules [249]. Moreover, the task-specific ILs combine to polymer membranes provide a remarkable selectivity and permeability for $\mathrm{CO}_{2}$ separation, which contain some specific anion or cation with promoted $\mathrm{CO}_{2}$ affinity $[255,256]$. In the ILPMs, the polymer membranes usually provide the mechanical strength, whereas ILs play a significant role in $\mathrm{CO}_{2}$ separation. 
For $\mathrm{CO}_{2}$ separation, ILs of ILPMs show more important for permeability and selectivity. First, the low viscosity and high $\mathrm{CO}_{2}$ permeability of IL are vital. They are attributed to $\mathrm{CO}_{2}$ solubility, and play significant roles in $\mathrm{CO}_{2}$ separation [230]. Second, higher IL contents results in a higher gas fluxes and faster separation for ILPMs. That because the mass transfer in IL is faster than in polymer matrixes. For example, Mannan et al. [231] suggested that incorporation of higher IL up to $50 \%$ into polymer matrix not only enhanced the permeability of the ILPMs but also improved the separation factor of the synthesized membranes. Chen et al. [230] found that permeability of $\mathrm{CO}_{2}$ increased rapidly with increasing IL content, which is attributed to the increments of $\mathrm{CO}_{2}$ diffusivity and solubility. They prepared $[\mathrm{Emim}]\left[\mathrm{B}(\mathrm{CN})_{4}\right] / \mathrm{PVDF}$ blend membranes showed a high $\mathrm{CO}_{2}$ permeability of 1778 barrer with $\mathrm{CO}_{2} / \mathrm{H}_{2}$ and $\mathrm{CO}_{2} / \mathrm{N}_{2}$ selectivity of 12.9 and 41.1. However, the mechanical properties of composited membrane including Young's modulus, tensile strength, and extension at break, were decreased with increasing IL content. Third, it is necessary to check the operating pressure for ILPMs due to the plasticization phenomena [249, 257]. Plasticization is a pressure-dependent phenomenon, which is showed by rise in permeability and fall selectivity suddenly after a threshold pressure [249]. Mannan group found for glassy polymer (PES) membrane that the permeability decreased with increasing pressure. When the IL content was $50 \mathrm{wt} \%$, the permeability of $\mathrm{CO}_{2}$ was 355.76 barrer at 5 bar and 298.84 barrer at 25 bar. There was no plasticization occurred in [Emim] $\left[\mathrm{NTf}_{2}\right] / \mathrm{PES}$ membranes [249]. More other applications of PILMs to remove $\mathrm{CO}_{2}$ are shown in Table 11.

Table 11. Summary of removing $\mathrm{CO}_{2}$ by ILPMs.

\begin{tabular}{|c|c|c|c|c|c|c|c|c|}
\hline \multirow{2}{*}{$\begin{array}{c}\text { Polymer } \\
\text { s }\end{array}$} & \multirow{2}{*}{ ILs } & \multicolumn{3}{|c|}{ Permeability (barrer) } & \multicolumn{2}{|c|}{ Selectivity } & \multirow{2}{*}{ Conditions } & \multirow{2}{*}{ Ref. } \\
\hline & & $\mathrm{CO}_{2}$ & $\mathrm{~N}_{2}$ & $\mathrm{CH}_{4}$ & $\mathrm{CO}_{2} / \mathrm{N}_{2}$ & $\mathrm{CO}_{2} / \mathrm{NH}_{4}$ & & \\
\hline \multirow{3}{*}{ PIM-1 } & {$\left[\mathrm{C}_{2} \mathrm{mim}\right]\left[\mathrm{NTf}_{2}\right] 5 \mathrm{wt} \%$} & 6650 & 332 & 593 & 20 & 11 & \multirow{3}{*}{$303 \mathrm{~K}$} & \multirow{3}{*}{ [258] } \\
\hline & {$\left[\mathrm{C}_{4} \mathrm{mim}\right]\left[\mathrm{NTf}_{2}\right] 5 \mathrm{wt} \%$} & 4590 & 212 & 349 & 22 & 13 & & \\
\hline & {$\left[\mathrm{C}_{6} \mathrm{mim}\right]\left[\mathrm{NTf}_{2}\right] 5 \mathrm{wt} \%$} & 2240 & 90 & 165 & 25 & 14 & & \\
\hline \multirow{3}{*}{ PSF } & {$[\mathrm{Bmim}][\mathrm{TFSI}] 50 \mathrm{wt} \%$} & 3000 & 107 & - & 28 & - & \multirow{3}{*}{$\begin{array}{l}308 \mathrm{~K} \\
7 \mathrm{bar}\end{array}$} & \multirow{3}{*}{ [183] } \\
\hline & [Bdim][TFSI] $50 \mathrm{wt} \%$ & 3600 & 129.9 & - & 27.7 & - & & \\
\hline & [Dems][TFSI] $50 \mathrm{wt} \%$ & 5800 & 193 & - & 30 & - & & \\
\hline \multirow{2}{*}{ PSF } & {$\left[\mathrm{P}_{4441}\right][$ formate $] 12.5 \mathrm{wt} \%$} & 17.3 & - & 0.48 & - & 31 & $295 \mathrm{~K}$ & \multirow{2}{*}{ [259] } \\
\hline & {$\left[\mathrm{DIP}-\mathrm{C}_{4} \mathrm{mim}\right]\left[\mathrm{NTf}_{2}\right] 2.5 \mathrm{wt} \%$} & 13.8 & - & 0.22 & - & 63 & 10 bar & \\
\hline
\end{tabular}




\begin{tabular}{|c|c|c|c|c|c|c|c|c|}
\hline & {$\left[\mathrm{C}_{4} \operatorname{mim}\right]\left[\mathrm{NTf}_{2}\right] 2.5 \mathrm{wt} \%$} & 11.5 & - & 0.16 & - & 70 & & \\
\hline & {$\left[\mathrm{N}_{4441}\right][$ formate] $0.5 \mathrm{wt} \%$} & 12.5 & - & 0.26 & - & 47 & & \\
\hline \multirow{8}{*}{ PVDF } & {$[\mathrm{Bmim}]\left[\mathrm{BF}_{4}\right]$} & 93.9 & 5.04 & 20.3 & 52.3 & 8.18 & \multirow{8}{*}{$\begin{array}{c}303 \mathrm{~K} \\
3 \mathrm{bar}\end{array}$} & \multirow{8}{*}{ [260] } \\
\hline & $\mathrm{AMMOEN}^{\mathrm{TM}} 100$ & 93.9 & 1.79 & 5.76 & 52.6 & 7.93 & & \\
\hline & $\mathrm{ECOENG}^{\mathrm{TM}} 1111 \mathrm{P}$ & 127 & 11.6 & 15.6 & 10.9 & 6.38 & & \\
\hline & Cyphos 102 & 637 & 15.3 & 76.5 & 41.5 & 6.87 & & \\
\hline & Cyphos 103 & 487 & 11.3 & 65.1 & 43.1 & 5.62 & & \\
\hline & Cyphos 104 & 642 & 20.3 & 11.3 & 31.6 & 5.17 & & \\
\hline & [Emim][OTf] & 486 & 14.3 & 21.1 & 34.0 & 13.1 & & \\
\hline & {$\left[\mathrm{Set}_{3}\right]\left[\mathrm{NTF}_{2}\right]$} & 747 & 18.4 & 81.2 & 26.2 & 6.67 & & \\
\hline \multirow{4}{*}{ PVDF } & {$\left[\mathrm{C}_{4} \mathrm{mim}\right]\left[\mathrm{PF}_{6}\right]$} & - & - & - & 20 & 200 & \multirow{4}{*}{$\begin{array}{l}303 \mathrm{~K} \\
1.7 \mathrm{bar}\end{array}$} & \multirow{4}{*}{ [261] } \\
\hline & {$\left[\mathrm{C}_{4} \mathrm{mim}\right]\left[\mathrm{BF}_{4}\right]$} & - & - & - & 32 & 102 & & \\
\hline & {$\left[\mathrm{C}_{4} \mathrm{mim}\right]\left[\mathrm{NTf}_{2}\right]$} & - & - & - & 30 & 161 & & \\
\hline & {$\left[\mathrm{C}_{8} \mathrm{mim}\right]\left[\mathrm{PF}_{6}\right]$} & - & - & - & 21 & 98 & & \\
\hline \multirow{3}{*}{ PES } & {$[\mathrm{MpFHim}]\left[\mathrm{NTf}_{2}\right]$} & 320 & 12 & 17 & 27 & 19 & \multirow{3}{*}{$\begin{array}{c}296 \mathrm{~K} \\
1.85 \mathrm{bar}\end{array}$} & \multirow{3}{*}{ [262] } \\
\hline & {$[\mathrm{MnFHim}]\left[\mathrm{NTf}_{2}\right]$} & 280 & 14 & 17 & 21 & 17 & & \\
\hline & {$[\mathrm{MtdFHim}]\left[\mathrm{NTf}_{2}\right]$} & 210 & 13 & 16 & 16 & 13 & & \\
\hline PI & {$[\mathrm{Bmim}]\left[\mathrm{NTf}_{2}\right]$} & 34.4 & 1.34 & 1.43 & 25.7 & 24.1 & $\begin{array}{c}308 \mathrm{~K} \\
-\end{array}$ & [248] \\
\hline
\end{tabular}

\subsection{Ionic liquids composited mixed matrix membranes (ILMMMs)}

4

5

6

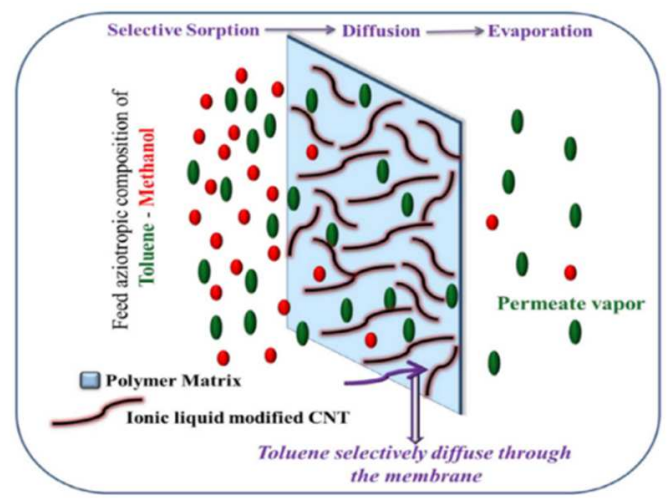

Figure 6. Schematic of ILMMMs selective separation of toluene [269].

Mixed matrix membranes (MMMs) are comprised of inorganic fillers and polymers. The separation performance of MMMs depends on the selective sorption/diffusion of the fillers, and 
1 the mechanical strength relies on polymer matrices [263]. According previous studies,

2 polymeric membranes are subjected to the trade-off effect between permeability and selectivity

3 [218], and poor processability [264]. MMMs combine outstanding gas separation performance

4 of inorganic materials and mechanical strength of polymer membranes. However, there are still

5 some challenges of MMMs should be solved. For example, selecting an appropriate filler and polymer [263], the filler dispersion [265], and the compatibility of filler and polymer [266]. Combining the ILs with inorganic fillers in MMMs (Figure 6) will enhance the membrane separation performance due to the synergistic effect [267]. In ILMMMs, ILs are used to increase the absorption capacity, and combine with polymer matrixes to further improve membranes separation performance [268].

\subsubsection{Separation of VOCs by ILMMMs}

Numerous MMMs combine with ILs have been synthesized using different fillers and polymers to enhance the compatibility between filler and polymer. But for their applications, a few studies are focus on VOCs separation. Abraham et al. [269] presented an IL modified multiwalled carbon nanotubes (MWCNT) based styrene butadiene rubber (SBR) composite membrane, which showed impressive separation performance for toluene selective separation from methanol/toluene mixture. The highest separation factor reached to 128.4 , which is 1.6 times of SBR membrane. This excellent performance was owning to the closeness of solubility parameter between toluene and SBR and interaction between benzyl groups of IL. Furthermore, they also discussed the influence of loading MWCNT and the effect of IL loading. The separation factor was increased first and then decreased with the MWCNT loading increasing. The effect of IL loading was similar to MWCNT. When the $5 \mathrm{phr}$-MWCNT and mixed with IL in ration 1:5 loaded membrane, the separation factor reached to the maximum 128.4. Moreover, the glass temperature was reduced with increasing IL content due to the plasticizing effect.

\subsubsection{Separation of $\mathrm{CO}_{2}$ by ILMMMs}

Recently, various types coupling agents have been investigated to improve the compatibility 
1 and $\mathrm{CO}_{2}$ separation performance of ILMMMs. For example, Li et al. [270] suggested a new

2 method to introduce [Bmim] $\left[\mathrm{NTf}_{2}\right]$ into zeolite imidazolate framework-8 (ZIF-8) and combine

3 with poly(ether-block-amide) (Pebax) polymer membrane. The results showed that mechanical

4 and gas separation properties of ILMMMs were improved simultaneously. On the other hand,

5 polymeric ILs (PILs) have polymer properties and ILs characteristics [271]. When RTILs were

6 loaded into PILs matrix, those composite membranes show excellent stability. For example, A

7 high performance PIL/IL/zeolite MMMs was prepared by Cowan et al. [272]. This membrane

8 showed ideal $\mathrm{CO}_{2}$ permeability was 261 barrer and $\mathrm{CO}_{2}$ selectivity from $\mathrm{CO}_{2} / \mathrm{CH}_{4}$ was up to

9 93. This outstanding performance can be explained by the presence of coulombic attraction between non-polymerizable IL and PIL matrix. Huang et al. [265] facilitated a new MMMs by

11 incorporating IL functionalized graphene oxide (GO-IL) into Pebax 1657. This membrane showed high $\mathrm{CO}_{2}$ permeance up to $9000 \mathrm{GPU}$ and the $\mathrm{CO}_{2} / \mathrm{N}_{2}$ and $\mathrm{CO}_{2} / \mathrm{H}_{2}$ selectivities of about 45 and 5.8 due to enhanced $\mathrm{CO}_{2}$ solubility by IL. More information of separating $\mathrm{CO}_{2}$ by ILMMMs are shown in Table 12.

Table 12. Summary on ILMMMs for $\mathrm{CO}_{2}$ separation.

\begin{tabular}{|c|c|c|c|c|c|c|c|}
\hline \multirow[b]{2}{*}{ ILMMMs } & \multicolumn{3}{|c|}{ Permeability (barrer) } & \multicolumn{2}{|c|}{ Selectivity } & \multirow[b]{2}{*}{ Conditions } & \multirow[b]{2}{*}{ Ref. } \\
\hline & $\mathrm{CO}_{2}$ & $\mathrm{~N}_{2}$ & $\mathrm{CH}_{4}$ & $\begin{array}{l}\mathrm{CO}_{2} \\
/ \mathrm{N}_{2}\end{array}$ & $\begin{array}{c}\mathrm{CO}_{2} / \mathrm{CH} \\
4\end{array}$ & & \\
\hline $\mathrm{PSF} /[\mathrm{bmim}]\left[\mathrm{NTf}_{2}\right] @ \mathrm{ZIF}-8$ & 350.7 & 2.18 & 8.77 & $\begin{array}{c}161 . \\
1\end{array}$ & 40 & $303 \mathrm{~K}, 6$ bar & [277] \\
\hline PEBAX1657/[bmim][NTf 2$] @ Z I F-8$ & 104.9 & 1.25 & 3.01 & 83.9 & 34.8 & $298 \mathrm{~K}, 1$ bar & [270] \\
\hline$[\mathrm{emim}][\mathrm{dca}] / \mathrm{P}([\mathrm{vbim}][\mathrm{dca}])$ & 272.9 & 5.1 & - & 53.5 & - & \multirow{2}{*}{$\begin{array}{l}308 \mathrm{~K} \\
1-2 \mathrm{bar}\end{array}$} & \multirow{2}{*}{ [278] } \\
\hline$[\mathrm{emim}]\left[\mathrm{B}(\mathrm{CN})_{4}\right] / \mathrm{P}([\mathrm{vbim}][\mathrm{dca}])$ & 340.1 & 8.10 & - & 42.0 & - & & \\
\hline$[\mathrm{bmim}]\left[\mathrm{CF}_{3} \mathrm{SO}_{3}\right] / \mathrm{Pebax} 1657$ & 320 & 8 & 11.85 & 40 & 27 & $298 \mathrm{~K}, 1$ bar & [251] \\
\hline$[\mathrm{bmim}][\mathrm{NTf} 2] / \mathrm{PI}$ & 510 & 18.48 & 35.17 & 27.6 & 14.5 & $308 \mathrm{~K}, 75 \mathrm{cmHg}$ & [247] \\
\hline$[\mathrm{emim}]\left[\mathrm{NTf}_{2}\right] / \mathrm{SAPO}-34 / \mathrm{P}($ vinyl-IL) & 527.2 & 20.28 & 21.16 & 26 & 24.9 & $296 \mathrm{~K}, 1-1.5$ bar & [279] \\
\hline$[\mathrm{emim}]\left[\mathrm{NTf}_{2}\right] / \mathrm{SAPO}-34 / \mathrm{P}\left([\mathrm{smim}]\left[\mathrm{NTf}_{2}\right]\right)$ & 260 & - & 2.89 & - & 90 & $298 \mathrm{~K}, 2$ bar & [280] \\
\hline \multirow{2}{*}[\mathrm{emim}]{$\left[\mathrm{B}(\mathrm{CN})_{4}\right] / \mathrm{ZIF}-8 / \mathrm{P}[\mathrm{vbim}]\left[\mathrm{NTf}_{2}\right]$} & 906.4 & 43.17 & - & 21 & - & \multirow{2}{*}{$308 \mathrm{~K}, 3.5$ bar } & \multirow{2}{*}{ [271] } \\
\hline & 928.7 & - & 80.06 & - & 11.6 & & \\
\hline \multirow{2}{*}{ [bmim][NTf 2$] / @ Z I F-8 / P S F$} & 279 & 2.15 & - & 130 & - & \multirow{2}{*}{$303 \mathrm{~K}, 6$ bar } & \multirow{2}{*}[277]{} \\
\hline & 253 & - & 5.54 & - & 45.7 & & \\
\hline $\begin{array}{l}\text { (3-aminopropyl)trimethoxysilano } \\
\text { acetate/@GO/Pebax } 1657\end{array}$ & 118.6 & 1.67 & - & 71 & - & $\begin{array}{c}298 \mathrm{~K} \\
4 \mathrm{bar}\end{array}$ & [264] \\
\hline$[\mathrm{emim}]\left[\mathrm{NTf}_{2}\right] / \mathrm{SAPO}-34 / \mathrm{PES}$ & - & - & - & - & 37.23 &,- 4 bar & [267] \\
\hline$[\mathrm{emim}]\left[\mathrm{NTf}_{2}\right] / \mathrm{SAPO}-34 / \mathrm{PES}$ & - & - & - & - & 62 & $\begin{array}{c}\text { room temperature, } \\
30 \mathrm{bar}\end{array}$ & [273] \\
\hline
\end{tabular}


Membrane separation performance is not only affected by filler and polymer, but also by operating conditions. Mohshim et al. [273] observed that $\mathrm{CO}_{2} / \mathrm{CH}_{4}$ selectivity of PES-SAPO34 modified [Emim] $\left[\mathrm{NTf}_{2}\right]$ membrane increased with increasing pressure. The similar results were observed by Huang et al. [265]. In addition, it was noticed that the $\mathrm{CO}_{2} / \mathrm{CH}_{4}$ ideal selectivity increased as the IL concentration increased. In conclusion, it is very important for development of ILMMMs to select an appropriate material for both sieve phase and matrix [97, 274]. Although lots of researchers have been devoted to carry out preparation and modification fillers and polymers in ILMMMs [275, 276], it is necessary to broaden the applications of ILMMMs, because few groups focus on removing VOCs by ILMMMs.

\subsection{Poly(ionic liquid)s membranes (PILMs)}

PILs were synthesized by polymerizable ILs. Usually, to obtain highly gas permeable and selective, ILs can be directly imbibed into porous membranes. In this case, ILs can be polymerized to form dense polymerized ionic liquid (PIL) membranes to resolve the mechanical stability issue. Poly(ionic liquid)s (PILs) possess many of the unique combination properties of ILs together with intrinsic polymer properties [281 - 284]. When PILs are used for greenhouse gas separation $[285,286]$, they exhibited excellent sorption capacities and desorption rates than the corresponding ionic monomers. For example, Cardiano et al [285] presented a series of PILs, also the properties of sorption for $\mathrm{CO}_{2}$ have been researched. The results showed that PIL exhibited significative fast and reversible $\mathrm{CO}_{2}$ sorption properties at room temperature. It is confirmed that ILs assembling on polymer network represents a useful method to get more processable ILs-materials for greenhouse gas separation. Additionally, Yuan et al. [286] synthesized amine-functionalized PIL brushes which exhibited enhanced $\mathrm{CO}_{2}$ adsorption capacity. When the polymer brush with polymer loading of $46 \mathrm{wt} \%$, the carbon dioxide adsorption capacity was $2.43 \mathrm{mmol} \mathrm{g}^{-1}$ at $298 \mathrm{~K}$ under 0.2 bar $\left(\mathrm{CO}_{2}\right.$ partial pressure), much higher than that value of the free polymer $\left(1.28 \mathrm{mmol} \mathrm{g}^{-1}\right)$ under the same conditions.

Due to their polymer macrostructure, PILMs not only have enhanced processability and durability, but also improved mechanical stability. To overcome low gas permeability and diffusivity, various strategies have occurred to improve the transport properties of PILMs 
1 include loading certain amounts of free room temperature ionic liquids (PIL-IL) [287 - 291], controlling chain packing by synthesizing PIL copolymer membranes [291, 292], and incorporating inorganic material [294, 295]. The synthesis of composite membranes by blending PILs with free non-polymerizable ILs seems to be the most promising strategy to obtain membranes that preserve the mechanical and thermal stability of common polymers which providing high permeation rates and separation factors, which are attractive for industrial purposes. Researchers [290] prepared composite membranes by polymerization of imidazolium-IL monomers in the presence $20 \mathrm{wt} \%$ of free IL, which results showed that the $\mathrm{CO}_{2}$ permeability increased by approximately $40 \%$. Then, PIL-IL composite membranes draw lots of attentions of researchers, and several PIL and IL combinations are studied [287 - 291]. Recently, there is reported that supported thin-firm (nano layers) of PIL-IL composites exhibit excellent $\mathrm{CO}_{2}$ permeation rates together with acceptable $\mathrm{CO}_{2} / \mathrm{N}_{2}$ selectivities [289], thus indicating that there is still a lot of spaces for improvement in the development of this type of membranes. Phosphonium-based PILs have primarily been synthesized by radical polymerization of IL monomers containing a quaternary phosphonium cation with three attached alkyl chains and a vinylbenzyl polymerizable group, along with an associated free cation. For example, controlled reversible addition-fragmentation chain-transfer polymerizations of $\left[\mathrm{P}_{\mathrm{n}} \mathrm{VB}\right][\mathrm{Cl}]$ (where $\mathrm{n}=$ the number of carbons in the alkyl chains and $\mathrm{VB}=$ the vinylbenzyl polymerizable group on the phosphonium cation) monomers have been used to produce linear PILs and block copolymers containing the phosphonium the phosphonium moiety [292]. Matthew G. Cowan et al. [293] studied the effect of cation alkyl chain length on phosphonium-based PILMs. They found that the gas permeability increased approximately linearly with increasing alkyl chain length on the phosphonium group. In addition, gas selectivity was observed to decrease with an increase in phosphonium alkyl chain length from $\mathrm{n}=4$ to $\mathrm{n}=6$, then remain approximately constant between $\mathrm{n}=6$ and $\mathrm{n}=8$. The prior works showed that the physical properties of phosphonium-based PILs were influenced on the length of alkyl chain length. Combining PILs with inorganic materials to improve the gas separation and permeability is a promising approach. For example, Yeny C. Hudiono et al. [279] showed that the non-volatile RTIL component enhanced the interaction between the zeolites particles and the poly(RTIL) matrix. Zeolites, RTILs and poly(RTIL)s have been found to be very 
1 promising materials for the separation of $\mathrm{CO}_{2}$ from other gases when formed into membranes.

\subsubsection{Separation of VOCs by PILMs}
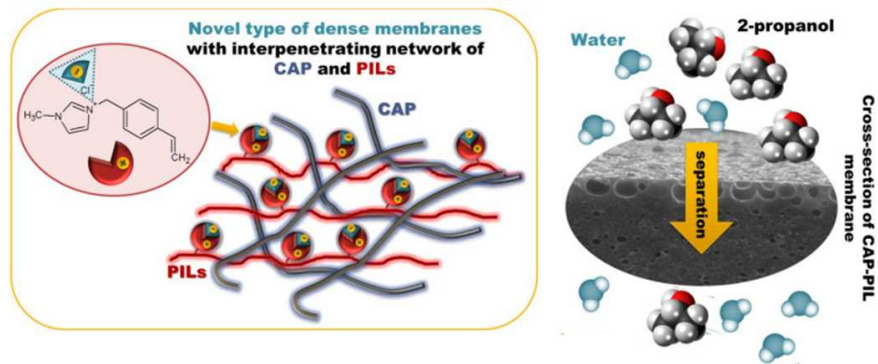

Figure 7. Schematic of poly(ionic liquid)s membrane [296].

Recently, the application of PILs as membrane materials has become one of the fastgrowing fields. Rynkowska et al. [296] prepared a new type of dense membrane (Figure 7) containing interpenetrating network of cellulose acetate propionate (CAP) and PIL. They also found that CAP-PIL membranes are efficient in separation of water and propan-2-ol. Furthermore, the physicochemical and transport properties of CAP-PIL membranes were investigated [297]. With increasing the PIL content, both the thermal stability and mechanical strength were increased. The immobilization of RIL in CAP membranes enhanced the hydrophilic properties of CAP-membrane surface. In addition, it was observed that PIL modified CAP membrane increase the swelling ability, which resulted the swelling of CAPbased membranes in contact with organic such as ethanol and propan-2-ol decreased.

PIL-based membranes have been investigated for many applications, such as gas separation [291], and wastewater treatment [298]. The properties and performance of PILMs can be tuned for the solvent properties by the PIL monomer and polymerization conditions [227]. The selectivity of membranes can be changed by swelling properties and surface charge, which depended on polymer monomer, polymerization methods and conditions $[228,299]$. Due to the wide variety of PIL monomers, the PIL-based membranes with different properties can be developed to meet different industrial separation requirements.

\subsubsection{Separation of $\mathrm{CO}_{2}$ by PILMs}

According to the approaches of improving gas separation, PILMs can be divided into three 
1 types such as homo-PIL membranes, PIL-IL membranes, and PIL-inorganic particle membranes. For homo-PIL membranes, Zhang et al. [300] found that the $\mathrm{CO}_{2}$ permeability gradually increased with increase of PIL content, and the best permeability and perm-selectivity of the membrane reach 36.1 barrer and 59.6. The semi-interpenetrating polymer network membrane was synthesized by incorporating polyvinyl acetate into a cross-linked PIL network, which showed an improved mechanical strength and a depressed glass transition temperature. Cong et al. [301] reported a PILs composited poly (2, 6-dimethyl-1, 4-phenylene oxide) membrane. However, this membrane enhanced $\mathrm{CO}_{2} / \mathrm{N}_{2}$ selectivity but sacrificed the permeability. Sum up, homo-PILMs usually show small $\mathrm{CO}_{2}$ permeability [288]. For PIL-IL membranes, ILs are regarded as a plasticizer and enhanced the $\mathrm{CO}_{2}$ permeability [302]. More importantly, when increase the IL loading, permeability improved without changing the selectivity [255]. Tome et al. [303] compared the gas permeation porperties of PIL-IL membranes with different cation pendants, such as imidazolium, pydridinium, pyrrolidinium, ammonium, and cholinium, combinated with the same counter-anion ([NTf 2$])$. When the free IL loading was $10 \%, \mathrm{CO}_{2}$ perm-selectivities of different anions PIL-IL membranes were ranging from 28.3 to 43.0 for $\mathrm{CO}_{2} / \mathrm{CH}_{4}$ and from 25.8 to 34.7 for $\mathrm{CO}_{2} / \mathrm{N}_{2}$. The best permselectivity were obtained by cholinium and pyrrolidinium better than other anions. In addition, they also tested the PIL-IL membranes with different anions including $\left[\mathrm{N}(\mathrm{CN})_{2}\right],\left[\mathrm{C}(\mathrm{CN})_{3}\right]$, $\left[\mathrm{B}(\mathrm{CN})_{4}\right]$, and $\left[\mathrm{NTf}_{2}\right]$. They found that the $\mathrm{CO}_{2}$ and $\mathrm{N}_{2}$ permeabilities were controlled by diffusivity mechanism, while the perm-selectivities of $\mathrm{CO}_{2}$ and $\mathrm{N}_{2}$ was a solubility-controlled process. Moreover, The $\mathrm{CO}_{2} / \mathrm{N}_{2}$ separation performance of PIL $\mathrm{C}(\mathrm{CN})_{3}-40 \mathrm{IL} \mathrm{N}(\mathrm{CN})_{2}, \mathrm{PIL}$ $\mathrm{N}(\mathrm{CN})_{2}-60 \mathrm{IL} \mathrm{C}(\mathrm{CN})_{3}$, PIL C(CN) $)_{3}-60 \mathrm{IL} \mathrm{B}(\mathrm{CN})_{4}$, and PIL B(CN) $)_{4}-60 \mathrm{IL} \mathrm{C}(\mathrm{CN})_{3}$ were on top of Robeson 2008 upper bound [304]. Some researchers indicated that increasing the content of free IL enhanced the permeabilities of gases. For PIL-inorganic particle membranes, composite PIL-IL membranes containing $\mathrm{CuCl}$ have been obtained by Zarca et al [289]. Results showed that enhancement of both gas permeability and ideal selectivity were observed for $\mathrm{CO}_{2} / \mathrm{N}_{2}$ and $\mathrm{H}_{2} / \mathrm{N}_{2}$. However, presence of $\mathrm{Cu}^{+}$did not promote facilitated transport of $\mathrm{CO}_{2}$. And decreased gas diffusion. More information of separating $\mathrm{CO}_{2}$ by PILMs are shown in Table 13. 
Table 13. Summary on major results of PILMs for $\mathrm{CO}_{2}$ separation.

3

\begin{tabular}{|c|c|c|c|c|}
\hline PILMs & Gas pairs & Conditions & Main conclusions & Ref. \\
\hline $\begin{array}{l}\text { Styrene-based PILMs } \\
\text { Acrylate-based PILMs }\end{array}$ & $\begin{array}{r}\mathrm{CO}_{2} / \mathrm{N}_{2} \\
\mathrm{CO}_{2} / \mathrm{CH}_{4}\end{array}$ & $293 \mathrm{~K}$ & $\begin{array}{l}\text { - } \mathrm{CO}_{2} \text { permeability was increased in a nonlinear } \\
\text { fashion as the n-alkyl substituent was } \\
\text { lengthened } \\
\text { - } \mathrm{CO}_{2} / \mathrm{N}_{2} \text { separation performance was relatively } \\
\text { unaffected as } \mathrm{CO}_{2} \text { permeability increase } \\
\text { - } \mathrm{CO}_{2} / \mathrm{CH}_{4} \text { ideal solubility selectivity was highest } \\
\text { when alkyl substituent was a methyl group } \\
\text { - PILMs can dissolve about twice as much } \\
\text { volume of } \mathrm{CO}_{2} \text { per cubic centimeter of material } \\
\text { than their liquid analogues at similar } \\
\text { temperature }\end{array}$ & [291] \\
\hline $\begin{array}{c}\text { Poly(1-[(4-ethenyl } \\
\text { phenyl)methyl]-3- } \\
\text { alkylimidazolium) bis- } \\
\text { (trifluoromethane)sulfonamide) } \\
\text { with PES membranes }\end{array}$ & $\mathrm{CO}_{2} / \mathrm{CH}_{4}$ & $\begin{array}{c}283-313 \mathrm{~K} \\
10-50 \mathrm{bar}\end{array}$ & $\begin{array}{l}\text { - PILs at single and mixed gas pressures up to } 40 \\
\text { bar and over a temperature range from } 283 \text { - } \\
313 \mathrm{~K} \\
\text { - The permeability of } \mathrm{CO}_{2} \text { increase by more than } \\
60 \% \text { over a pressure range of } 40 \mathrm{bar} \\
\text { - Plasticizing effect of the absorbed } \mathrm{CO}_{2} \text { resulting } \\
\text { in a strong increase in } \mathrm{CH}_{4} \text { permeability with } \\
\text { increasing feed pressure } \\
\text { - The permeability of } \mathrm{CO}_{2} \text { is not suppressed by } \\
\text { the presence of } \mathrm{CH}_{4}\end{array}$ & [302] \\
\hline $\begin{array}{c}\text { Poly(diphenylacetylene)s } \\
\text { containing imidazolium salts } \\
\text { membranes }\end{array}$ & $\mathrm{CO}_{2} / \mathrm{N}_{2}$ & $\begin{array}{c}298 \mathrm{~K} \\
-\end{array}$ & $\begin{array}{l}\text { - High free volume polymers with ionic groups } \\
\text { enhanced } \mathrm{CO}_{2} \text { separation selectivity } \\
\text { - } \mathrm{CO}_{2} \text { permeability reached } 250 \text { barrer, and } \\
\text { selectivity of } \mathrm{CO}_{2} / \mathrm{CH}_{4} \text { was ranging from } 31 \text { to } \\
44 \\
\text { - Introduction of 1-methylimidazole into the } \\
\text { membranes remarkable increased the } \mathrm{CO}_{2} / \mathrm{N}_{2} \\
\text { selectivity, but decreased the } \mathrm{CO}_{2} \text { permeability }\end{array}$ & [305] \\
\hline
\end{tabular}




\begin{tabular}{|c|c|c|c|c|}
\hline $\begin{array}{c}\text { DVB-cross-linked } \\
\text { poly }\left(\left[\mathrm{P}_{\mathrm{nnnVB}}\right]\left[\mathrm{NTf}_{2}\right]\right) \text { ion gel } \\
\text { membrane containing the free } \\
\text { ILs }\left[\mathrm{P}_{4448}\right]\left[\mathrm{NTf}_{2}\right],\left[\mathrm{P}_{8888}\right]\left[\mathrm{NTf}_{2}\right] \\
\text { and }[\mathrm{emim}]\left[\mathrm{NTf}_{2}\right]\end{array}$ & $\begin{array}{c}\mathrm{CO}_{2} / \mathrm{N}_{2} \\
\mathrm{CO}_{2} / \mathrm{CH}_{4} \\
\mathrm{CO}_{2} / \mathrm{H}_{2}\end{array}$ & $\begin{array}{c}298 \mathrm{~K} \\
-\end{array}$ & $\begin{array}{l}\text { - Shorter alky chain lengths on the phosphonium } \\
\text { cation of the IL resulted in increased thermal } \\
\text { stability of the ionic conductivity for the } \\
\text { resulting PIL/IL membrane materials with } \\
\text { negligible changes in ionic conductivity } \\
\text { performance at temperatures up to } 383 \mathrm{~K} \\
\text { - Increasing of free IL loading resulted in an } \\
\text { increase in overall membrane mechanical } \\
\text { stability and gas permeabilities } \\
\text { - Significantly higher gas permeabilities were } \\
\text { observed for ion gel membranes containing the } \\
\text { [P8888] cation (162 barrer) }\end{array}$ & [306] \\
\hline $\begin{array}{l}\text { Styrene-based IL monomers } \\
\text { containing branched- and } \\
\text { cycloalkyl groups formed } \\
\text { PILMs }\end{array}$ & $\begin{array}{c}\mathrm{CO}_{2} / \mathrm{N}_{2} \\
\mathrm{CO}_{2} / \mathrm{CH}_{4}\end{array}$ & - & $\begin{array}{l}\text { - PILs with branched and cyclic functionalities } \\
\text { exhibited around } 20 \% \text { larger } \mathrm{CO}_{2} / \mathrm{N}_{2} \text { and } \\
\mathrm{CO}_{2} / \mathrm{CH}_{4} \text { selectivities, but gas permeability } \\
\text { decreased more than } 50 \% \\
\text { - PILMs with n-alkyl groups displayed increasing } \\
\mathrm{CO}_{2} \text { permeability with increasing number of } \\
\text { carbons in the pendant group }\end{array}$ & [307] \\
\hline
\end{tabular}

\subsection{Ionic liquid-gel membranes (ILGMs)}

In contrast to chemical polymerization, IL can be gelled physically using low organic gelators or polymers as a simpler fabrication alternative. Typically, an IL-gel membrane is prepared by mixing small amount of a low-molecular weight organic gelator (LMOG) with the chosen IL at elevated temperatures [308, 309]. When the samples were cooled down, a physical gel forms due to hydrogen-bonding or /and van der Waals forces from the gelator and IL to generate a dilute noncovalent network throughout the sample [310]. The IL-gel membranes suffer from a "flux-mechanical stability trade-off", which means increasing the weight fraction of the gelator that will improve the membrane mechanical stability, however, sacrifice the permeability. LOMG-gelled membranes are difficult to be processed into some shapes like thin film, which inhibits the applications of the membranes. On the contrary, polymers as gelling 
agents are more attractive as the gelled membranes are capable of being packed into large modules for easy retrofitting. IL-gel materials are booming because they maintain liquid-like gas transport properties in a solid state, which is much easier to handle and to prepare membrane modules for industrial applications.

\subsubsection{Separation of VOCs by ILGMs}

Although some of the separation performances of ILGMs are promising, the number of gelators known to gel room temperature ILs is limited. Moreover, the thermal stability of the IL-gel membranes is another limitation by the temperature at which the gel reversibly becomes a fluid $[251,311]$. Therefore, new gelators could gel IL with higher thermal stability and have the ability gel functionalization room temperature ILs with enhanced VOCs affinity. This kind of gelators are required the further development of the IL-gel membrane platform. Plaza et al. [312] researched the separation of acetone-butanol-ethanol mixtures from aqueous solution by membrane which synthetized by the gelation of an ionic liquid ([Bmim] $\left[\mathrm{PF}_{6}\right]$ ) and polytetrafluoroethylene hollow fibers. Improved butanol/ethanol selectivity was verified and they also found the membrane have potential for separation of butanol form these mixtures. Furthermore, the selectivity of membrane was mainly depended on the partition coefficient between the IL gel and aqueous solution. A gel membrane based on $20 \mathrm{wt} \%$ of poly(vinylidene fluoride-co-hexafluoropylene) with $80 \mathrm{wt} \%$ of $\left[\mathrm{C}_{2} \mathrm{mim}\right]\left[\mathrm{NTf}_{2}\right]$ for ethanol removing from polluted air was reported by O. Vopicka et al. [308]. In this system, ethanol permeability reached around 25000 barrer in the membrane at the highest ethanol vapor activity. Moreover, the ethanol vapor sorption in membrane increased with temperature.

\subsubsection{Separation of $\mathrm{CO}_{2}$ by ILGMs}

The main separation performances of ILGMs focus on biogases separating. Fam et al. [229] reported adefect-free Pebax 1675/[Emim][BF $]$ (1-ethyl-3-methylimidazolium tetrafluoroborate) gel membranes with high mechanical strength and improved $\mathrm{CO}_{2}$ separation performance. The stability of high IL-loaded gel membrane with up to 8 bar feed pressure also has possibility to meet industrial gas separation required. When the IL loading $80 \mathrm{wt} \%$, the $\mathrm{CO}_{2}$ permeability was 
increased $300 \%$ and ideal $\mathrm{CO}_{2} / \mathrm{CH}_{4}$ and $\mathrm{CO}_{2} / \mathrm{N}_{2}$ selectivities were 36 and 15 . Friess et al. [314] synthesized epoxy-amine-based ion-gel membranes showing remarkable $\mathrm{CO}_{2} / \mathrm{CH}_{4}$ separation performance even in presence of humidity. Introduction of humidity in the mixed-gas feeds leads to higher $\mathrm{CO}_{2} / \mathrm{CH}_{4}$ separation factor (up to 35) compared with dry mixed-gas feeds. In addition, an increase of free IL [Emim] $\left[\mathrm{NTf}_{2}\right]$ content from 50 to $75 \mathrm{wt} \%$ leads to higher $\mathrm{CO}_{2}$ permeability from 195 to 525 barrer with slight loss of $\mathrm{CO}_{2} / \mathrm{CH}_{4}$ ideal selectivity from 20 to 18 . Moghadam et al. [315] also studied ILGMs for $\mathrm{CO}_{2}$ separation under humid conditions. At room temperature, the membrane exhibited good stability at high relative humidity (RH). More importantly, at $303 \mathrm{~K}, \mathrm{RH} 70 \%$, and a $\mathrm{CO}_{2}$ partial pressure of $0.1 \mathrm{kPa}$, the membrane showed high $\mathrm{CO}_{2}$ permeability (around 50000 barrer) and $\mathrm{CO}_{2} / \mathrm{N}_{2}$ selectivity (up to 8100 ). Mahdavi et al. [310] introduced inorganic particles into ILGMs to promote gas permeabilities and ideal selectivities. The results showed that incorporation of $8 \mathrm{wt} \% \mathrm{SiO}_{2}$ increased $\mathrm{CO}_{2}$ and $\mathrm{CH}_{4}$ permeabilities values from 104.3 to 153.6 barrer and from 5.6 to 8.1 barrer. The ideal selectivities of $\mathrm{CO}_{2} / \mathrm{CH}_{4}$ increased from 18.5 to 19.1 at 2 bar $298 \mathrm{~K}$. However, Couto et al. [313] developed a new gel membrane, which showed much lower permeability and ideal selectivity for $\mathrm{CO}_{2}$, comparing to other gel membranes.

Above all, although some of, ILGMs show high mechanical strength and gas permeability, the gelators to gel ILs are limited. In addition, the thermal stability of ILGMs is hindered its applications. On the other word, the gelled ILs will change the morphology with temperature increasing. Therefore, development of new gelators with high thermal stability is necessary. And it is also significant to find new method to gel functionalized ILs with higher affinity of target gas, and exploitation of new applications of ILGMs.

\subsection{Ionic liquid membrane contactors (ILMCs)}

Membrane absorption [54, 323 - 325] is a hybrid process that integrates the advantages of membrane separation and absorption, where liquid absorbents provide the selectivity and the porous/unselective membrane acts as the contacting interface between liquid and gas phases. There are lots of advantages of membrane contactor [326 - 329], such as determined interfacial area, independent control of gas and liquid flow rates, and avoidance to drop dragging. For most 
1 of the cases, membrane contactor is applied for gas capture at relatively low pressure and temperature [330 - 332]. Various aqueous absorbents have been studied in membrane contactors, including aqueous amine solutions [335, 343], amino salt solutions [335 - 337], enzyme solutions [338, 339], and ammonia solutions [340 - 342]. Based on liquid flow direction, there are co-current, cross flow, and counter-current configurations of membrane contactors [343]. Based on the structures of membrane, there are flat and hollow fiber membranes. Moreover, there are polymeric and ceramic membranes according to the materials of membrane used. For the type and geometry, hollow fiber membrane contactors are widely applied due to large mass transfer area [329, 344 - 346]. Hollow fiber membrane contactors (HFMCs) have become attractive for gas separation due to high volume, higher active surface areas, and toleration of long-term operation. [316]. The gas separation performance of HFMCs is mainly affected by pore size and its distribution, selective shin layer thickness, membrane materials and fabrication conditions [316, 318]. A lot of researchers are attention to improve gas separation performance of HFMCs [319 - 322]. The use of ILs in HFMC processes can bring new opportunities in the use of HFMCs in gas separation. For the type of materials, hydrophobic polymeric membranes are popular due to high porosity and wide availability [347, 349].

Currently, ILs-based membrane contactor is a new concept that needs to be demonstrated. The excellent thermal stability of the IL component will enable higher temperature applications, and the negligible vapor pressure of the IL will sharply reduce solvent loss and regeneration energy, compared to traditional absorbents.

\subsubsection{Separation of VOCs by ILMCs}

ILs in membrane contactors used as absorbents based on affinities for VOCs. FHILMCs are preferred by industrial applications over flat membranes because the separation processes take the advantages of the hollow fiber morphology by trapping IL within the micro-porous of the fiber wall [317, 318]. Hollow fibers ionic liquid membrane contactors (HFILMCs), have been developed to separate VOCs with long-term operation of membrane processes. Kim et al. [320] fabricated a polyacrylonitrile HFMC by less toxic IL solvent instead of DMF. From this method, they obtained a uniform pattern and high porosity of the inner surface of HFM. Zhang et al. 
1 [321] obtained the hollow fiber renewal ionic liquid membranes that are interested because they

2 allow the solvent phase to be continuously renewed. Because of low melting point, viscosity

3 and relatively low cost, n-butylpyridinium tetrafluorodorate $\left([\mathrm{Bpy}]\left[\mathrm{BF}_{4}\right]\right)$ and $\left[\mathrm{Bmim}^{2}\right]\left[\mathrm{BF}_{4}\right]$

4 were used to separate toluene from cyclohexane solution (Figure 8). The selectivity of HFILMC

5 processes was larger than 10 at the temperature $323 \mathrm{~K}$. Moreover, this membrane showed a good long-term stability due to the high viscosity of IL. Furthermore, hollow fiber configurations have been also studied with gelled ionic liquids to promote the mechanical strength. The processes of gelation enable the ILs into the polymeric supported, which preventing ILs release to the surrounding phase. Plaza et al. [312] synthetized a membrane by the gelation of an ionic liquid $[\mathrm{Bmim}]\left[\mathrm{PF}_{6}\right]$ into porosity of polytetrafluoroethylene (PTFE) hollow fibers. During the whole experiments, losses of IL of gelled ILHFMs were not observed, which were more stable than the membrane without 12-hydroxystearic acid gelator. They suggested that the gelled ionic liquid HFMC favored the separation of butanol, while the HFMC without IL preferred acetone. Snochowska et al. [343] reported polypropylene HFILMC with 1-butyl-3-methtlimidazolium methyl sulfate ([Bmim][MeSO 4$]$ ) separated ethanol from aqueous solutions. The experiments were carried out with feed concentrations range from 1 to 5 wt.\% and feed flow rates range from 1 to $8 \mathrm{dm}^{3} \mathrm{~h}^{-1}$. The results showed the efficiency of ethanol used this contactor was around $20 \%$, which was considered satisfactory of industrial requirement. Ortiz et al. [349] compared separation performance of two different contactors including a membrane contactor (MC) and a semi-tank reactor with same $\mathrm{IL} \mathrm{Ag}^{+}$modified $[\mathrm{Bmim}]\left[\mathrm{BF}_{4}\right]$ as reactive media. These contactors were used to separate propylene from propylene/propane gas mixtures. They found that the contactor showed lower mass transfer coefficient, however, the overall resistance of mass transport was decreased, and absorption rate and capacity of contactor were increased. Finally, the separation performance of contactor was more attractive than semi-tank reactors under same operating conditions. 

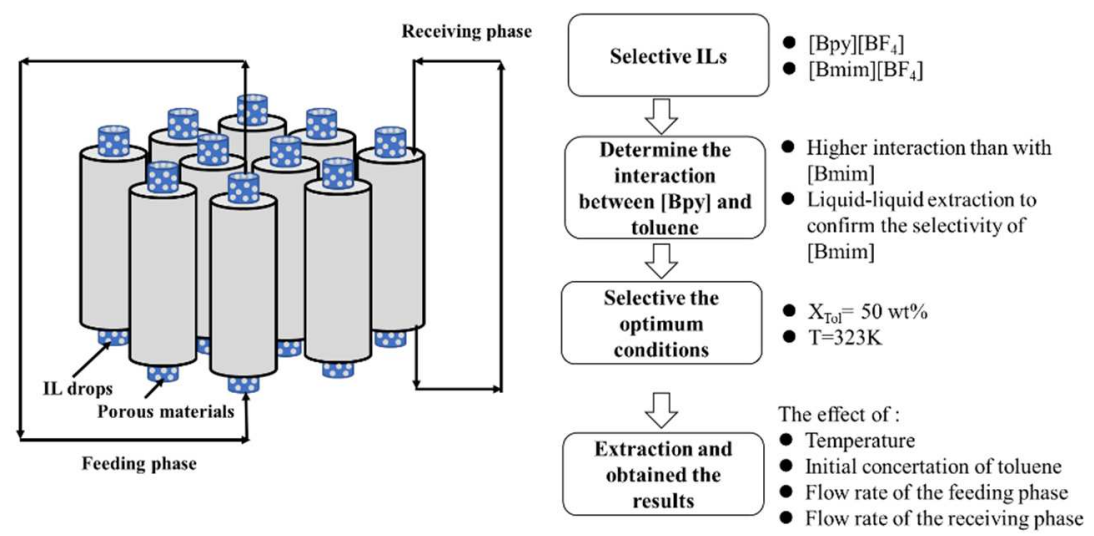

Figure 8. Hollow fiber supported ILMs by Zhang et al [321]

\subsubsection{Separation of $\mathrm{CO}_{2}$ by ILMCs}

ILMCs processes with ionic liquids also widely used to $\mathrm{CO}_{2}$ separation, especially HFILMCs. Until now, there are lots of reports focus on removing gas, such as $\mathrm{CO}_{2}, \mathrm{CO}$ [350], and $\mathrm{SO}_{2}$ [351], using ILs in membrane contactors due to their extremely high interfacial area from membranes and high selectivity from ILs. The main drawback of membrane contactors is wetting of membrane pores, which decreased the mass transport $[355,356]$ and pressure difference between the liquid and gas side of membrane [352 - 354, 357]. The methods used to reduce wetting effects are divided into following two parts: i) using composite hollow fiber membrane contactors; ii) using a dense membrane contactor with high permeable to $\mathrm{CO}_{2}$.

Because of the wetting-effect, porous polymeric hollow fiber membrane contractors are more popular. Rostami et al. [332] researched the effects of $\left[\mathrm{Bmim}^{-1}\left[\mathrm{BF}_{4}\right]\right.$ on the absorption $\mathrm{CO}_{2}$ using polypropylene hollow fiber membrane contactors. They also investigated the effects of different operating parameters including concentration of IL in water, liquid and gas flow rates, and flow direction. The results showed that adding IL into the water, the $\mathrm{CO}_{2}$ solubility and viscosity of the solution were increased and diffusion coefficient of $\mathrm{CO}_{2}$ in the solution was decreased. The resistance of mass transfer in liquid phase decrease by increasing the flow rate of liquid. Moreover, when the gas flow rate increase, higher amount of gas enters the membrane contactor resulting in the increase of mass transfer flux. For the direction of gas and liquid flows, the counter-current flow has a higher efficiency than the co-current flow because the countercurrent flow keeps high mass transfer through the length of membrane. Besides, the effects of 
1 temperature on $\mathrm{CO}_{2}$ capture were studied by Gomez-Coma et al. [178]. They demonstrated that the $\mathrm{CO}_{2}$ removal efficiency was dependent on temperature. For instance, when the temperature increased from 291 to $348 \mathrm{~K}$, the $\mathrm{CO}_{2}$ removal efficiency was increased from 30 to $45 \%$. Furthermore, this research group studied the dry and wet PVDF hollow fiber membrane contactors with 1-ethyl-3-methylpyridinium ethylsulfate ([Emim] $\left[\mathrm{EtSO}_{4}\right]$ ) to absorbed $\mathrm{CO}_{2}$ [358]. They indicated that the fibers in dry form showed higher $\mathrm{CO}_{2}$ permeability than in the wet form, and the permeability increased by $43 \%$ due to in presence of immobilized IL. Wickramanayake et al. [321] designed a four morphology of polymeric HFILMCs, which were fabricated using Matrimid and $[\mathrm{Hmim}]\left[\mathrm{NTf}_{2}\right]$. The primary of this study was to optimize the porosity of the support affecting gas separation performance. The porosity of membranes was subjected to the polymer content. The porosity of membrane was increased by decreasing the polymer content. It was found that the $\mathrm{CO}_{2}$ permeance and the $\mathrm{CO}_{2} / \mathrm{H}_{2}$ selectivity of membrane were increased with increasing the porosity in micro-porous region because of higher IL content in selective layer of fibers. However, it was should be noted that a high porosity is beneficial to the gas separation, while there are some negative effects on mechanical strength of membrane. Furthermore, they also studied the structural stability by same types of HFILMCs with different polymeric matrixes [322]. In this system they fabricated polymeric HFILMs containing 1hexyl-3-methylimidazolium bis(trifluoromethysulfonyl)imide ([ $\left.\left.\mathrm{C}_{6} \mathrm{mim}\right]\left[\mathrm{NTf}_{2}\right]\right)$ with Matrimid and Torlon matrixes. By using sufficiently high fiber porosity and thus maximizing the IL content of the membrane, it was found that Torlon fibers have improved mechanical strength compared with Matrimid. The study of Kim et al. [179] focused on improving the $\mathrm{CO}_{2}$ permeability and stability of the HFILMs composited by [Emim] $\left[\mathrm{NTf}_{2}\right]$ and PVDF. They indicated that the gas permeability and stability were affected by support structure. Two structures of hollow support obtained such as sponge-like and finger-like, and sponge-like hollow support showed higher stability than finger-like under 1.5 bar. And for gas separation, they observed $\mathrm{CO}_{2}$ permeability over 2600 barrer and selectivity of $\mathrm{CO}_{2} / \mathrm{N}_{2}$ was from 30-33.

The gas separation performance of HFILMCs is depended on the following factors [317, 318, 321]: i) porosity and pore size, which control the selectivity of membrane; ii) selective skin layer thickness, which decides the membrane flux; iii) materials and fabrication of 
1 membrane, which govern the gas permeability and perm-selectivity. However, the HFILMCs also show a few problems, for example poor stability and the fabrication condition of membrane, which limit the applications of HFILMCs. For the industrial applications, the HFILMCs should meet the requirements of both good transport and mechanical properties, as well as find suitable approaches to address these competing interests.

Additionally, the nonporous composite membrane with thin dense top layer also provides an opportunity to eliminate the effect of pore wetting. For example, Bazhenov et al. [357] designed a gas-liquid membrane contactor to capture $\mathrm{CO}_{2}$. This dense flat-sheet membrane contactor was composed by [1-(trimethylsilyl)-1-propyne] and nine different RTILs. According to the solvent-polymer membrane compatibility, $[\mathrm{Emim}]\left[\mathrm{BF}_{4}\right]$ were selected to apply in contactor. They revealed that the solvent-membrane interaction is mainly determined by the liquid surface tension rather than viscosity and molecular size of RTILs. In addition, membrane contactors using both porous and nonporous polymeric HFMCs with 1-butyl-3methylimidazolium tricyanomethanide ([Bmim][TCM]) were developed and compared as $\mathrm{CO}_{2}$ capture by Dai et al. [359]. According to the compatibility and stability of different polymeric membranes, the porous PTFE and nonporous Teflon-PP membranes were selected to separate $\mathrm{CO}_{2}$. The effects of operating pressure and gas flow rate were investigated both porous and nonporous membranes. It was found that the operating pressure has opposite effect on $\mathrm{CO}_{2}$ flux of two membranes, with a more significant effect on the porous membrane. Additionally, higher gas flow rate results in higher $\mathrm{CO}_{2}$ flux in both membranes, while the porous membrane contactor presents a higher $\mathrm{CO}_{2}$ flux and nonporous membrane contactor exhibits better longterm stability.

Besides, many challenges for IL-based membrane contactors still need to be overcome. Firstly, low surface tension of ILs, which leads to easy membrane pore-wetting $[1,168,355$, 356]. Another challenge is that the ILs are generally good solvents also for polymers [228, 229], which means ILs might dissolve some polymeric membranes or polymer-based sealing materials gradually. In addition, the toxicity and potential environmental impacts of many ILs [154, 360 - 362] are still not clear, although commonly ILs are accepted as green solvents. Moreover, the high price of ILs is also a drawback. 


\section{4. Conclusion}

Different kinds of membrane processes relating to use of ILs for VOCs or $\mathrm{CO}_{2}$ removal are discussed, which showed better performance than conventional processes. Table 14 shows a comprehensive summary of advantages and disadvantages on ILs membrane processes for VOCs or $\mathrm{CO}_{2}$ separation.

Table 14. Advantages and disadvantages of membrane processes containing ILs.

\begin{tabular}{|c|c|c|}
\hline Membranes & Advantages & Disadvantages \\
\hline SILMs & $\begin{array}{l}\text { - High interfacial area per unit volume for mass } \\
\text { transfer } \\
\text { - Low solvent holding } \\
\text { - More efficient in application over other liquid } \\
\text { membrane processes }\end{array}$ & $\begin{array}{l}\text { - In over-time operation, the liquid phase } \\
\text { evaporates or is pushed out of the membrane } \\
\text { pores, resulting in a non-selective transport } \\
\text { - Thick membranes will exhibit improved } \\
\text { stability and reasonable lifetimes but lower gas } \\
\text { flux } \\
\text { - Regeneration is complicated and difficult }\end{array}$ \\
\hline ILPMs & $\begin{array}{l}\text { - Unique combination properties of ILs and intrinsic } \\
\text { polymer properties } \\
\text { - Prevent the membrane from excessive swelling } \\
\text { and maintain the gas separation performances even } \\
\text { at increased temperature and pressure conditions }\end{array}$ & $\begin{array}{l}\text { - Gas permeability and diffusivity are hindered } \\
\text { through the solid polymer matrix } \\
\text { - Plasticization phenomena occurred } \\
\text { - Limited by Robeson upper bound line } \\
\text { - Weak thermal and mechanical stability }\end{array}$ \\
\hline ILMMMs & $\begin{array}{l}\text { - Membrane performances including permeability } \\
\text { and selectivity were enhanced due to the } \\
\text { synergetic effect between ILs and fillers } \\
\text { - Added inorganic fillers will increase the } \\
\text { sorption/diffusion } \\
\text { - ILs help to improve the interfacial voids in the } \\
\text { MMMs } \\
\text { - Relative higher thermal and mechanical properties } \\
\text { than others }\end{array}$ & $\begin{array}{l}\text { - ILs could cause pore blockage in porous matrix } \\
\text { - Surface voids and filler agglomeration affect the } \\
\text { gas separation and structures of membranes } \\
\text { - Poor polymers and inorganic fillers } \\
\text { compatibility }\end{array}$ \\
\hline
\end{tabular}




\begin{tabular}{|c|c|c|}
\hline PILMs & $\begin{array}{l}\text { - PILs modified membranes show tunable charge, } \\
\text { wettability } \\
\text { - Improved mechanical properties } \\
\text { - Promoted both gas permeability and ideal } \\
\text { selectivity } \\
\text { - RTILs with polymerizable groups can convert into } \\
\text { solid, which composite dense membranes resulting } \\
\text { in a friendly process }\end{array}$ & $\begin{array}{l}\text { - Separation performances of PILMs are mainly } \\
\text { depended on polymer monomer, polymeric } \\
\text { methods } \\
\text { - The stability of membrane needs improved by } \\
\text { adding plasticizers }\end{array}$ \\
\hline ILGMs & $\begin{array}{l}\text { - Liquid-like gas transport properties in a solid state, } \\
\text { which is easier to handle and to prepare membrane } \\
\text { modules for industrial applications } \\
\text { - Gas permeability is increased }\end{array}$ & $\begin{array}{l}\text { - Thermal and mechanical stability are limited } \\
\text { - Gas permeability and ideal selectivity are low } \\
\text { - Gelators are limited } \\
\text { - High packing density is required } \\
\text { - Suffering the trade-off effect between signal gas } \\
\text { permeability and selectivity of gas pair }\end{array}$ \\
\hline ILMCs & $\begin{array}{l}\text { - Long-time operation } \\
\text { - Higher active surface area to volume ratio } \\
\text { - Allow the solvent phase to be continuously } \\
\text { renewed } \\
\text {-low resistance of gas flow } \\
\text { - Self-supporting structure } \\
\text { - Ability to perform at high pressure } \\
\text { - Determined interfacial area } \\
\text { - Independent control of gas and liquid flow rates } \\
\text { - Avoidance the drop dragging } \\
\text { - Reduce the solvent loss and regeneration energy }\end{array}$ & $\begin{array}{l}\text { - Poor stability and processability } \\
\text { - Selection of materials is limited } \\
\text { - Some ILs can dissolve the polymeric or } \\
\text { polymer-based sealing membrane } \\
\text { - Low surface tension of ILs }\end{array}$ \\
\hline
\end{tabular}

2 separation processes have become increasingly important. Although great progress has been

3 done on removal of VOCs or $\mathrm{CO}_{2}$ on ILs and membrane separation processes, there are still

4 knowledge gaps that need to be filled. Additional studies are still needing to: i) improve VOCs or $\mathrm{CO}_{2}$ adsorption capacity of ILs and membrane separation processes; ii) reduce toxicity of

6 ILs and overcome the limitations related to the stability, which can broaden the range of 7 applications of ILs; iii) increase the selectivity and stability of ILs and membrane; iv) simplify 8 recycling processes of ILs and adsorbed $\mathrm{VOCs}$ or $\mathrm{CO}_{2}$; v) decrease the cost of adsorbent and membrane set-up equipment; vi) solve the difficulty of high boiling VOCs desorption. 
$1 \mathrm{CO}_{2}$ removal by green and economic processes based on ILs and membrane separation in the 2 not distant future.

3 
Names and abbreviations of ILs

\begin{tabular}{|c|c|}
\hline \multicolumn{2}{|r|}{ Names and abbreviations of ILs } \\
\hline Abbreviations & Names \\
\hline$[\mathrm{Abim}]\left[\mathrm{NTf}_{2}\right]$ & 1-allyl-3-butylimidazolium bis(trifluoromethanesulfonyl)imide \\
\hline$[\mathrm{Bmim}][\mathrm{Ac}]$ & 1-buthyl-3-methylimidazolium acetate \\
\hline$[\mathrm{Bmim}]\left[\mathrm{PF}_{6}\right]$ & 1-butyl-3-methylimidazolium hexafluorophosphate \\
\hline$[\mathrm{Bmim}]\left[\mathrm{BF}_{4}\right]$ & 1-butyl-3-methylimidazolium tetrafluoroborate \\
\hline$[\mathrm{Bmim}]\left[\mathrm{NTf}_{2}\right]$ & 1-butyl-3-methylimidazolium bis(trifluoromethylsulfonyl)imide \\
\hline$[\mathrm{Bpy}]\left[\mathrm{BF}_{4}\right]$ & n-butylpyridinium tetrafluorodorate \\
\hline$[\mathrm{Bmim}][\mathrm{TCM}]$ & 1-butyl-3-methylimidazolium tricyanomethanide \\
\hline$[\mathrm{Bmim}]\left[\mathrm{MeSO}_{4}\right]$ & 1-butyl-3-methylimidazolium methylsulfate \\
\hline $\begin{array}{l}{\left[\mathrm{C}_{\mathrm{n}} \operatorname{mim}\right]\left[\mathrm{NTf}_{2}\right]} \\
(\mathrm{n}=2,4,6)\end{array}$ & (1-alkyl-3-methylimidazolium bis(trifluoromethylsulfonyl)imide \\
\hline$\left[\mathrm{C}_{2} \mathrm{mim}\right]\left[\mathrm{BF}_{4}\right]$ & 1-ethyl-3-methylimidazolium tetrafluoroborate \\
\hline $\begin{array}{l}{\left[\mathrm{C}_{\mathrm{n}} \operatorname{mim}\right]\left[\mathrm{BF}_{4}\right]} \\
(\mathrm{n}=4,6-8,12)\end{array}$ & 1-n-althyl-3-methylimidazolium tetrafluorobrate \\
\hline$\left[\mathrm{C}_{8} \mathrm{mim}\right]\left[\mathrm{PF}_{6}\right]$ & 1-n-octyl-3-methylimidazolium hexafluorophosphate \\
\hline$\left[\mathrm{C}_{3} \mathrm{NH}_{2} \mathrm{mim}\right]\left[\mathrm{NTf}_{2}\right]$ & n-aminopropyl-3-methylimidazolium bis(trifluoromethylsulfonyl)imide \\
\hline$\left[\mathrm{C}_{4} \mathrm{C}_{1} \mathrm{im}\right]\left[\mathrm{BF}_{4}\right]$ & 1-butyl-3-methylimidazolium tetrafluoroborate \\
\hline$\left[\mathrm{C}_{\mathrm{n}} \mathrm{C}_{1} \mathrm{im}\right]\left[\mathrm{PF}_{6}\right]$ & 1-butyl-3-methylimidazolium hexafluorophosphate $(n=4)$ \\
\hline$(\mathrm{n}=4$ or 6$)$ & 1-hexyl-3-methylimidazolium hexafluorophosphate ( $\mathrm{n}=6$ ) \\
\hline [Choline][Pro] & (2-hydroxyethyl)-trimethyl-ammonium(S)-2-pyrrolidinecarboxylic \\
\hline$\left[\mathrm{C}_{2} \mathrm{mim}\right][\mathrm{TCB}]$ & 1-ethyl-3-methylimidazolium tetracyanoborate \\
\hline$[\mathrm{Emim}]\left[\mathrm{BF}_{4}\right]$ & 1-ethyl-3-methylimidazolium tetrafluoroborate \\
\hline$[$ Emim $][D C A]$ & 1-ethyl-3-methylimidazolium dicyanoamide \\
\hline$[\mathrm{Emim}]\left[\mathrm{EtSO}_{4}\right]$ & 1-ethyl-3-methylimidazolium ethylsulfate \\
\hline$[$ Emim $]\left[\mathrm{NTf}_{2}\right]$ & 1-ethyl-3-methylimidazolium bis(trifluoromethylsulfonyl)imide \\
\hline$[\mathrm{Emim}][\mathrm{Ac}]$ & 1-ethyl-3-methylimidazolium acetate \\
\hline$\left[\right.$ Empy] $\left[\mathrm{EtSO}_{4}\right]$ & 1-ethyl-3-methylpyridinium ethylsulfate \\
\hline$[\mathrm{Hmim}]\left[\mathrm{PF}_{6}\right]$ & 1-hexyl-3-methylimidazolium hexafluorophosphate \\
\hline$[\mathrm{Hmim}]\left[\mathrm{NTf}_{2}\right]$ & 1-hexyl-3-methylimidazolium bis(trifluoromethylsulfonyl)imide \\
\hline$\left[\mathrm{N}_{444}\right][$ formate $]$ & tributylmethylammonium formate \\
\hline$[\mathrm{Omim}][\mathrm{TCM}]$ & 1-methyl-3-octylimidazolium tricyanomethanide \\
\hline$[\mathrm{Omim}]\left[\mathrm{PF}_{6}\right]$ & 1-methyl-3-octylimidazolium hexafluorophosphate \\
\hline$\left[\mathrm{P}_{444}\right][$ formate $]$ & tributylmethylphosphonium formate \\
\hline
\end{tabular}

2

3 Acknowledgments

$4 \quad$ China Scholarship Council for partial financial support (201701810017) 
[1] M.J. Salar-García, V.M. Ortiz-Martínez, F.J. Hernández-Fernández, A.P. de los Ríos, J. Quesada-Medina, Ionic liquid technology to recover volatile organic compounds (VOCs), J. Hazard. Mater. 321 (2017) 484499. doi:10.1016/j.jhazmat.2016.09.040.

[2] M. Lei, S. Wu, G. Liu, S. Amirkhanian, VOCs characteristics and their relation with rheological properties of base and modified bitumens at different temperatures, Constr. Build. Mater. 160 (2018) 794-801. doi:10.1016/j.conbuildmat.2017.12.158.

[3] M. Schiavon, L.M. Martini, C. Corrà, M. Scapinello, G. Coller, P. Tosi, M. Ragazzi, Characterisation of volatile organic compounds (VOCs) released by the composting of different waste matrices, Environ. Pollut. 231 (2017) 845-853. doi:10.1016/j.envpol.2017.08.096.

[4] S. Malakar, P.D. Saha, D. Baskaran, R. Rajamanickam, Comparative study of biofiltration process for treatment of VOCs emission from petroleum refinery wastewater-A review, Environ. Technol. Innov. 8 (2017) 441-461. doi:10.1016/j.eti.2017.09.007.

[5] L. Yu, L. Wang, W. Xu, L. Chen, M. Fu, J. Wu, D. Ye, Adsorption of VOCs on reduced graphene oxide, J. Environ. Sci. 67 (2018) 171-178. doi:10.1016/j.jes.2017.08.022.

[6] D. Dobslaw, A. Schulz, S. Helbich, C. Dobslaw, K.-H. Engesser, VOC removal and odor abatement by a low-cost plasma enhanced biotrickling filter process, J. Environ. Chem. Eng. 5 (2017) 5501-5511. doi:10.1016/j.jece.2017.10.015.

[7] X. Zhang, B. Gao, A.E. Creamer, C. Cao, Y. Li, Adsorption of VOCs onto engineered carbon materials: A review, J. Hazard. Mater. 338 (2017) 102-123. doi:10.1016/j.jhazmat.2017.05.013.

[8] M. Tamaddoni, R. Sotudeh-Gharebagh, S. Nario, M. Hajihosseinzadeh, N. Mostoufi, Experimental study of the VOC emitted from crude oil tankers, Process Saf. Environ. Prot. 92 (2014) 929-937. doi:10.1016/j.psep.2013.10.005.

[9] H. Guo, Z.H. Ling, H.R. Cheng, I.J. Simpson, X.P. Lyu, X.M. Wang, M. Shao, H.X. Lu, G. Ayoko, Y.L. Zhang, S.M. Saunders, S.H.M. Lam, J.L. Wang, D.R. Blake, Tropospheric volatile organic compounds in China, Sci. Total Environ. 574 (2017) 1021-1043. doi:10.1016/j.scitotenv.2016.09.116.

[10] N. Saeaw, S. Thepanondh, Source apportionment analysis of airborne VOCs using positive matrix factorization in industrial and urban areas in Thailand, Atmospheric Pollut. Res. 6 (2015) 644-650. doi:10.5094/APR.2015.073.

[11] X.P. Lyu, N. Chen, H. Guo, W.H. Zhang, N. Wang, Y. Wang, M. Liu, Ambient volatile organic compounds and their effect on ozone production in Wuhan, central China, Sci. Total Environ. 541 (2016) 200-209. doi:10.1016/j.scitotenv.2015.09.093.

[12] Z.H. Ling, H. Guo, Contribution of VOC sources to photochemical ozone formation and its control policy implication in Hong Kong, Environ. Sci. Policy. 38 (2014) 180-191. doi:10.1016/j.envsci.2013.12.004. [13] A.F. Stein, E. Mantilla, M.M. Millán, Using measured and modeled indicators to assess ozone-NOxVOC sensitivity in a western Mediterranean coastal environment, Atmos. Environ. 39 (2005) 7167-7180. doi:10.1016/j.atmosenv.2005.08.026.

[14] A. Luengas, A. Barona, C. Hort, G. Gallastegui, V. Platel, A. Elias, A review of indoor air treatment technologies, Rev. Environ. Sci. Biotechnol. 14 (2015) 499-522. doi:10.1007/s11157-015-9363-9.

[15] E. Durmusoglu, F. Taspinar, A. Karademir, Health risk assessment of BTEX emissions in the landfill environment, J. Hazard. Mater. 176 (2010) 870-877. doi:10.1016/j.jhazmat.2009.11.117.

[16] Y. Liu, Y. Liu, H. Li, X. Fu, H. Guo, R. Meng, W. Lu, M. Zhao, H. Wang, Health risk impacts analysis of fugitive aromatic compounds emissions from the working face of a municipal solid waste landfill in China, 
Environ. Int. 97 (2016) 15-27. doi:10.1016/j.envint.2016.10.010.

[17] J.A. Bernstein, N. Alexis, H. Bacchus, I.L. Bernstein, P. Fritz, E. Horner, N. Li, S. Mason, A. Nel, J. Oullette, K. Reijula, T. Reponen, J. Seltzer, A. Smith, S.M. Tarlo, The health effects of nonindustrial indoor air pollution, J. Allergy Clin. Immunol. 121 (2008) 585-591. doi:10.1016/j.jaci.2007.10.045.

[18] L. Curtis, W. Rea, P. Smith-Willis, E. Fenyves, Y. Pan, Adverse health effects of outdoor air pollutants, Environ. Int. 32 (2006) 815-830. doi:10.1016/j.envint.2006.03.012.

[19] N.A.B. Mabahwi, O.L.H. Leh, D. Omar, Human Health and Wellbeing: Human Health Effect of Air Pollution, Procedia - Soc. Behav. Sci. 153 (2014) 221-229. doi:10.1016/j.sbspro.2014.10.056.

[20] M. Kampa, E. Castanas, Human health effects of air pollution, Environ. Pollut. 151 (2008) 362-367. doi:10.1016/j.envpol.2007.06.012.

[21] R.E. Tapscott, J.D. Mather, Tropodegradable fluorocarbon replacements for ozone-depleting and globalwarming chemicals, J. Fluor. Chem. 101 (2000) 5. doi:10.1016/S0022-1139(99)00161-X.

[22] S. Ojala, S. Pitkäaho, T. Laitinen, N. Niskala Koivikko, R. Brahmi, J. Gaálová, L. Matejova, A. Kucherov, S. Päivärinta, C. Hirschmann, T. Nevanperä, M. Riihimäki, M. Pirilä, R.L. Keiski, Catalysis in VOC Abatement, Top. Catal. 54 (2011) 1224-1256. doi:10.1007/s11244-011-9747-1.

[23] X. Zhang, B. Gao, A.E. Creamer, C. Cao, Y. Li, Adsorption of VOCs onto engineered carbon materials: A review, J. Hazard. Mater. 338 (2017) 102-123. doi:10.1016/j.jhazmat.2017.05.013.

[24] J. Dengchao, T. Hongjun, B. Zhenbo, L. Yang, Content and Formation Cause of VOCs in Medical Waste Non-incineration Treatment Project, IOP Conf. Ser. Earth Environ. Sci. 113 (2018) 012005. doi:10.1088/1755-1315/113/1/012005.

[25] K. Andrew, An Overview of Incineration and EFW Technology as Applied to the Management of Municipal Solid Waste (MSW), University of Western Ontario, (2008).

[26] M.R. Beychok, Fossil fuel combustion flue gases, Encyclopedia of Earth, 2012.

[27] M. Jabłońska, A. Król, E. Kukulska-Zając, K. Tarach, V. Girman, L. Chmielarz, K. Góra-Marek, Zeolites Y modified with palladium as effective catalysts for low-temperature methanol incineration, Appl. Catal. B Environ. 166-167 (2015) 353-365. doi:10.1016/j.apcatb.2014.11.047.

[28] M. Jabłońska, M. Nocuń, E. Bidzińska, Silver-Alumina Catalysts for Low-Temperature Methanol Incineration, Catal. Lett. 146 (2016) 937-944. doi:10.1007/s10562-016-1713-x.

[29] X. Qian, D. Yue, Z. Tian, M. Reng, Y. Zhu, M. Kan, T. Zhang, Y. Zhao, Carbon quantum dots decorated $\mathrm{Bi}_{2} \mathrm{WO}_{6}$ nanocomposite with enhanced photocatalytic oxidation activity for VOCs, Appl. Catal. B Environ. 193 (2016) 16-21. doi:10.1016/j.apcatb.2016.04.009.

[30] L. Ren, Y. Li, J. Hou, J. Bai, M. Mao, M. Zeng, X. Zhao, N. Li, The pivotal effect of the interaction between reactant and anatase $\mathrm{TiO}_{2}$ nanosheets with exposed $\{001\}$ facets on photocatalysis for the photocatalytic purification of VOCs, Appl. Catal. B Environ. 181 (2016) 625-634. doi:10.1016/j.apcatb.2015.08.034.

[31] S. Weon, J. Choi, T. Park, W. Choi, Freestanding doubly open-ended $\mathrm{TiO}_{2}$ nanotubes for efficient photocatalytic degradation of volatile organic compounds, Appl. Catal. B Environ. 205 (2017) 386-392. doi:10.1016/j.apcatb.2016.12.048.

[32] S. Suárez, I. Jansson, B. Ohtani, B. Sánchez, From titania nanoparticles to decahedral anatase particles: Photocatalytic activity of $\mathrm{TiO}_{2}$ /zeolite hybrids for VOCs oxidation, Catal. Today. (2018). doi:10.1016/j.cattod.2018.09.004.

[33] V. Héquet, C. Raillard, O. Debono, F. Thévenet, N. Locoge, L. Le Coq, Photocatalytic oxidation of VOCs at ppb level using a closed-loop reactor: The mixture effect, Appl. Catal. B Environ. 226 (2018) 473486. doi:10.1016/j.apcatb.2017.12.041. 
[34] X. Qian, M. Ren, D. Yue, Y. Zhu, Y. Han, Z. Bian, Y. Zhao, Mesoporous $\mathrm{TiO}_{2}$ films coated on carbon foam based on waste polyurethane for enhanced photocatalytic oxidation of VOCs, Appl. Catal. B Environ. 212 (2017) 1-6. doi:10.1016/j.apcatb.2017.04.059.

[35] O. Debono, V. Hequet, L. Le Coq, N. Locoge, F. Thevenet, VOC ternary mixture effect on ppb level photocatalytic oxidation: Removal kinetic, reaction intermediates and mineralization, Appl. Catal. B Environ. 218 (2017) 359-369. doi:10.1016/j.apcatb.2017.06.070.

[36] M.S. Kamal, S.A. Razzak, M.M. Hossain, Catalytic oxidation of volatile organic compounds (VOCs) A review, Atmos. Environ. 140 (2016) 117-134. doi:10.1016/j.atmosenv.2016.05.031.

[37] Y. Liu, J. Deng, S. Xie, Z. Wang, H. Dai, Catalytic removal of volatile organic compounds using ordered porous transition metal oxide and supported noble metal catalysts, Chin. J. Catal. 37 (2016) 1193-1205. doi:10.1016/S1872-2067(16)62457-9.

[38] M.V. Gallegos, M.A. Peluso, E. Finocchio, H.J. Thomas, G. Busca, J.E. Sambeth, Removal of VOCs by catalytic process. A study of $\mathrm{MnZnO}$ composites synthesized from waste alkaline and $\mathrm{Zn} / \mathrm{C}$ batteries, Chem. Eng. J. 313 (2017) 1099-1111. doi:10.1016/j.cej.2016.11.001.

[39] Z. Zhang, Z. Jiang, W. Shangguan, Low-temperature catalysis for VOCs removal in technology and application: A state-of-the-art review, Catal. Today. 264 (2016) 270-278. doi:10.1016/j.cattod.2015.10.040. [40] M. Piumetti, D. Fino, N. Russo, Mesoporous manganese oxides prepared by solution combustion synthesis as catalysts for the total oxidation of VOCs, Appl. Catal. B Environ. 163 (2015) 277-287. doi:10.1016/j.apcatb.2014.08.012.

[41] J. Ji, Y. Xu, H. Huang, M. He, S. Liu, G. Liu, R. Xie, Q. Feng, Y. Shu, Y. Zhan, R. Fang, X. Ye, D.Y.C. Leung, Mesoporous $\mathrm{TiO}_{2}$ under VUV irradiation: Enhanced photocatalytic oxidation for VOCs degradation at room temperature, Chem. Eng. J. 327 (2017) 490-499. doi:10.1016/j.cej.2017.06.130.

[42] P. Yang, S. Yang, Z. Shi, Z. Meng, R. Zhou, Deep oxidation of chlorinated VOCs over $\mathrm{CeO}_{2}$-based transition metal mixed oxide catalysts, Appl. Catal. B Environ. 162 (2015) 227-235. doi:10.1016/j.apcatb.2014.06.048.

[43] Y. Shu, J. Ji, Y. Xu, J. Deng, H. Huang, M. He, D.Y.C. Leung, M. Wu, S. Liu, S. Liu, G. Liu, R. Xie, Q. Feng, Y. Zhan, R. Fang, X. Ye, Promotional role of Mn doping on catalytic oxidation of VOCs over mesoporous $\mathrm{TiO}_{2}$ under vacuum ultraviolet (VUV) irradiation, Appl. Catal. B Environ. 220 (2018) 78-87. doi:10.1016/j.apcatb.2017.08.019.

[44] S. Zhang, J. You, C. Kennes, Z. Cheng, J. Ye, D. Chen, J. Chen, L. Wang, Current advances of VOCs degradation by bioelectrochemical systems: A review, Chem. Eng. J. 334 (2018) 2625-2637. doi:10.1016/j.cej.2017.11.014.

[45] S. Mudliar, B. Giri, K. Padoley, D. Satpute, R. Dixit, P. Bhatt, R. Pandey, A. Juwarkar, A. Vaidya, Bioreactors for treatment of VOCs and odours - A review, J. Environ. Manage. 91 (2010) 1039-1054. doi:10.1016/j.jenvman.2010.01.006.

[46] S. Malakar, P.D. Saha, D. Baskaran, R. Rajamanickam, Comparative study of biofiltration process for treatment of VOCs emission from petroleum refinery wastewater-A review, Environ. Technol. Innov. 8 (2017) 441-461. doi:10.1016/j.eti.2017.09.007.

[47] H. Huang, H. Huang, Y. Zhan, G. Liu, X. Wang, H. Lu, L. Xiao, Q. Feng, D.Y.C. Leung, Efficient degradation of gaseous benzene by VUV photolysis combined with ozone-assisted catalytic oxidation: Performance and mechanism, Appl. Catal. B Environ. 186 (2016) 62-68. doi:10.1016/j.apcatb.2015.12.055. [48] S. Sultana, A.M. Vandenbroucke, C. Leys, N. De Geyter, R. Morent, Abatement of VOCs with Alternate Adsorption and Plasma-Assisted Regeneration: A Review, Catalysts. 5 (2015) 718-746. doi:10.3390/catal5020718. 
[49] S. Xian, Y. Yu, J. Xiao, Z. Zhang, Q. Xia, H. Wang, Z. Li, Competitive adsorption of water vapor with VOCs dichloroethane, ethyl acetate and benzene on MIL-101(Cr) in humid atmosphere, RSC Adv. 5 (2014) 1827-1834. doi:10.1039/C4RA10463C.

[50] H. Zaitan, M.H. Manero, H. Valdés, Application of high silica zeolite ZSM-5 in a hybrid treatment process based on sequential adsorption and ozonation for VOCs elimination, J. Environ. Sci. 41 (2016) 5968. doi:10.1016/j.jes.2015.05.021.

[51] R.R. Gil, B. Ruiz, M.S. Lozano, M.J. Martín, E. Fuente, VOCs removal by adsorption onto activated carbons from biocollagenic wastes of vegetable tanning, Chem. Eng. J. 245 (2014) 80-88. doi:10.1016/j.cej.2014.02.012.

[52] R. Valenciano, E. Aylón, M.T. Izquierdo, A Critical Short Review of Equilibrium and Kinetic Adsorption Models for VOCs Breakthrough Curves Modelling, Adsorpt. Sci. Technol. 33 (2015) 851-869. doi:10.1260/0263-6174.33.10.851.

[53] K.M. Kinder, C.A. Gellasch, J.S. Dusenbury, T.C. Timmes, T.M. Hughes, Evaluating the impact of ambient benzene vapor concentrations on product water from Condensation Water From Air technology, Sci. Total Environ. 590-591 (2017) 60-68. doi:10.1016/j.scitotenv.2017.02.171.

[54] B. Belaissaoui, Y. Le Moullec, E. Favre, Energy efficiency of a hybrid membrane/condensation process for VOC (Volatile Organic Compounds) recovery from air: A generic approach, Energy. 95 (2016) 291-302. doi:10.1016/j.energy.2015.12.006.

[55] E. Dumont, A. Couvert, A. Amrane, C. Couriol, G. Darracq, P. Le Cloirec, Equivalent Absorption Capacity (EAC) concept applied to the absorption of hydrophobic VOCs in a water/PDMS mixture, Chem. Eng. J. 287 (2016) 205-216. doi:10.1016/j.cej.2015.11.020.

[56] J.C. Ge, N.J. Choi, Fabrication of Functional Polyurethane/Rare Earth Nanocomposite Membranes by Electrospinning and Its VOCs Absorption Capacity from Air, Nanomaterials. 7 (2017) 60. doi:10.3390/nano7030060.

[57] R. Hariz, J.I. del Rio Sanz, C. Mercier, R. Valentin, N. Dietrich, Z. Mouloungui, G. Hébrard, Absorption of toluene by vegetable oil-water emulsion in scrubbing tower: Experiments and modeling, Chem. Eng. Sci. 157 (2017) 264-271. doi:10.1016/j.ces.2016.06.008.

[58] M. Guillerm, A. Couvert, A. Amrane, É. Dumont, E. Norrant, N. Lesage, C. Juery, Characterization and selection of PDMS solvents for the absorption and biodegradation of hydrophobic VOCs, J. Chem. Technol. Biotechnol. 91 (2016) 1923-1927. doi:10.1002/jctb.4792.

[59] W. Wang, X. Ma, S. Grimes, H. Cai, M. Zhang, Study on the absorbability, regeneration characteristics and thermal stability of ionic liquids for VOCs removal, Chem. Eng. J. 328 (2017) 353-359. doi:10.1016/j.cej.2017.06.178.

[60] J.Y. Zhou, B.F. Wang, L.H. Nie, J.X. Lu, Y.J. Hao, R.R. Xu, Experimental study on emission of VOCs from tanker using hollow fiber membrane absorption method with different absorbents, IOP Conf. Ser. Mater. Sci. Eng. 292 (2018) 012113. doi:10.1088/1757-899X/292/1/012113.

[61] S. Al-Gharabli, W. Kujawski, Z.A. El-Rub, E.M. Hamad, J. Kujawa, Enhancing membrane performance in removal of hazardous VOCs from water by modified fluorinated PVDF porous material, J. Membr. Sci. 556 (2018) 214-226. doi:10.1016/j.memsci.2018.04.012.

[62] B. Ozturk, C. Kuru, H. Aykac, S. Kaya, VOC separation using immobilized liquid membranes impregnated with oils, Sep. Purif. Technol. 153 (2015) 1-6. doi:10.1016/j.seppur.2015.08.032.

[63] H. Zhou, Y. Su, X. Chen, J. Luo, Y. Wan, High-performance PDMS membranes for pervaporative removal of VOCs from water: The role of alkyl grafting, J. Appl. Polym. Sci. 133 (2016). doi:10.1002/app.43700. 
[64] J.C. Ge, Z.J. Wang, M.S. Kim, N.J. Choi, VOCs Air Pollutant Cleaning with Polyacrylonitrile/Fly Ash Nanocomposite Electrospun Nanofibrous Membranes, IOP Conf. Ser. Mater. Sci. Eng. 301 (2018) 012036. doi:10.1088/1757-899X/301/1/012036.

[65] H. Chen, H. Zhang, Y. Yan, Fabrication of porous copper/manganese binary oxides modified ZSM-5 membrane catalyst and potential application in the removal of VOCs, Chem. Eng. J. 254 (2014) 133-142. doi:10.1016/j.cej.2014.05.083.

[66] S. Yi, Y. Wan, Volatile organic compounds (VOCs) recovery from aqueous solutions via pervaporation with vinyltriethoxysilane-grafted-silicalite-1/polydimethylsiloxane mixed matrix membrane, Chem. Eng. J. 313 (2017) 1639-1646. doi:10.1016/j.cej.2016.11.061.

[67] I.A. Aguayo-Villarreal, M.A. Montes-Morán, V. Hernández-Montoya, A. Bonilla-Petriciolet, A. Concheso, C.K. Rojas-Mayorga, J. González, Importance of iron oxides on the carbons surface vs the specific surface for VOC's adsorption, Ecol. Eng. 106 (2017) 400-408. doi:10.1016/j.ecoleng.2017.05.043.

[68] X. Yang, H. Yi, X. Tang, S. Zhao, Z. Yang, Y. Ma, T. Feng, X. Cui, Behaviors and kinetics of toluene adsorption-desorption on activated carbons with varying pore structure, J. Environ. Sci. 67 (2018) 104-114. doi:10.1016/j.jes.2017.06.032.

[69] R. Cherbański, Regeneration of granular activated carbon loaded with toluene - Comparison of microwave and conductive heating at the same active powers, Chem. Eng. Process. - Process Intensif. 123 (2018) 148-157. doi:10.1016/j.cep.2017.11.008.

[70] M. Li, S.C. Wu, Y.-H. Peng, Y. Shih, Adsorption of volatile organic vapors by activated carbon derived from rice husk under various humidity conditions and its statistical evaluation by linear solvation energy relationships, Sep. Purif. Technol. 170 (2016) 102-108. doi:10.1016/j.seppur.2016.06.029.

[71] G.B. Baur, I. Yuranov, A. Renken, L. Kiwi-Minsker, Activated carbon fibers for efficient VOC removal from diluted streams: the role of surface morphology, Adsorption. 21 (2015) 479-488. doi:10.1007/s10450015-9685-5.

[72] M. Wołowiec, B. Muir, K. Zięba, T. Bajda, M. Kowalik, W. Franus, Experimental Study on the Removal of VOCs and PAHs by Zeolites and Surfactant-Modified Zeolites, Energy Fuels. 31 (2017) 8803-8812. doi:10.1021/acs.energyfuels.7b01124.

[73] Y. Zhou, L. Zhou, X. Zhang, Y. Chen, Preparation of zeolitic imidazolate framework-8 /graphene oxide composites with enhanced VOCs adsorption capacity, Microporous Mesoporous Mater. 225 (2016) 488-493. doi:10.1016/j.micromeso.2016.01.047.

[74] Y. Wang, D. Yang, S. Li, M. Chen, L. Guo, J. Zhou, Ru/hierarchical HZSM-5 zeolite as efficient bifunctional adsorbent/catalyst for bulky aromatic VOCs elimination, Microporous Mesoporous Mater. 258 (2018) 17-25. doi:10.1016/j.micromeso.2017.08.052.

[75] V.K. Saini, J. Pires, Development of metal organic framework-199 immobilized zeolite foam for adsorption of common indoor VOCs, J. Environ. Sci. 55 (2017) 321-330. doi:10.1016/j.jes.2016.09.017. [76] J. Zhang, C. Rao, H. Peng, C. Peng, L. Zhang, X. Xu, W. Liu, Z. Wang, N. Zhang, X. Wang, Enhanced toluene combustion performance over Pt loaded hierarchical porous MOR zeolite, Chem. Eng. J. 334 (2018) 10-18. doi:10.1016/j.cej.2017.10.017.

[77] L. Pasti, E. Rodeghero, E. Sarti, V. Bosi, A. Cavazzini, R. Bagatin, A. Martucci, Competitive adsorption of VOCs from binary aqueous mixtures on zeolite ZSM-5, RSC Adv. 6 (2016) 54544-54552. doi:10.1039/C6RA08872D.

[78] J. Wu, L. Jia, L. Wu, C. Long, W. Deng, Q. Zhang, Prediction of the breakthrough curves of VOC isothermal adsorption on hypercrosslinked polymeric adsorbents in a fixed bed, RSC Adv. 6 (2016) 2898628993. doi:10.1039/C6RA01310D. 
[79] S. Wang, L. Zhang, C. Long, A. Li, Enhanced adsorption and desorption of VOCs vapor on novel micromesoporous polymeric adsorbents, J. Colloid Interface Sci. 428 (2014) 185-190. doi:10.1016/j.jcis.2014.04.055.

[80] W.-Q. Wang, J. Wang, J.-G. Chen, X.-S. Fan, Z.-T. Liu, Z.-W. Liu, J. Jiang, Z. Hao, Synthesis of novel hyper-cross-linked polymers as adsorbent for removing organic pollutants from humid streams, Chem. Eng. J. 281 (2015) 34-41. doi:10.1016/j.cej.2015.06.095.

[81] R. Vinodh, E.M. Jung, M. Ganesh, M.M. Peng, A. Abidov, M. Palanichamy, W.S. Cha, H.T. Jang, Novel microporous hypercross-linked polymers as sorbent for volatile organic compounds and $\mathrm{CO}_{2}$ adsorption, $\mathrm{J}$. Ind. Eng. Chem. 21 (2015) 1231-1238. doi:10.1016/j.jiec.2014.05.039.

[82] M. Ghafari, J.D. Atkinson, Impact of styrenic polymer one-step hyper-cross-linking on volatile organic compound adsorption and desorption performance, J. Hazard. Mater. 351 (2018) 117-123. doi:10.1016/j.jhazmat.2018.02.051.

[83] C. Della Pina, M.A. De Gregorio, L. Clerici, P. Dellavedova, E. Falletta, Polyaniline (PANI): an innovative support for sampling and removal of VOCs in air matrices, J. Hazard. Mater. 344 (2018) 308-315. doi:10.1016/j.jhazmat.2017.10.012.

[84] A. Hamad, M.E. Fayed, Simulation-Aided Optimization of Volatile Organic Compounds Recovery Using Condensation, Chem. Eng. Res. Des. 82 (2004) 895-906. doi:10.1205/0263876041596724.

[85] M. Krichevskaya, S. Preis, A. Moiseev, N. Pronina, J. Deubener, Gas-phase photocatalytic oxidation of refractory VOCs mixtures: Through the net of process limitations, Catal. Today. 280 (2017) 93-98. doi:10.1016/j.cattod.2016.03.041.

[86] A. Ikhlaq, B. Kasprzyk-Hordern, Catalytic ozonation of chlorinated VOCs on ZSM-5 zeolites and alumina: Formation of chlorides, Appl. Catal. B Environ. 200 (2017) 274-282. doi:10.1016/j.apcatb.2016.07.019.

[87] G. Swetha, T. Gopi, S. Chandra Shekar, C. Ramakrishna, B. Saini, P.V.L. Rao, Combination of adsorption followed by ozone oxidation with pressure swing adsorption technology for the removal of VOCs from contaminated air streams, Chem. Eng. Res. Des. 117 (2017) 725-732. doi:10.1016/j.cherd.2016.11.036. [88] K.L. Pan, D.L. Chen, G.T. Pan, S. Chong, M.B. Chang, Removal of phenol from gas streams via combined plasma catalysis, J. Ind. Eng. Chem. 52 (2017) 108-120. doi:10.1016/j.jiec.2017.03.031.

[89] S.K. Padhi, S. Gokhale, Biological oxidation of gaseous VOCs - rotating biological contactor a promising and eco-friendly technique, J. Environ. Chem. Eng. 2 (2014) 2085-2102. doi:10.1016/j.jece.2014.09.005.

[90] G. Xu, F. Liang, Y. Yang, Y. Hu, K. Zhang, W. Liu, An Improved $\mathrm{CO}_{2}$ Separation and Purification System Based on Cryogenic Separation and Distillation Theory, Energies. 7 (2014) 3484-3502. doi:10.3390/en7053484.

[91] D. Aaron, C. Tsouris, Separation of $\mathrm{CO}_{2}$ from Flue Gas: A Review, Sep. Sci. Technol. 40 (2005) 321348. doi:10.1081/SS-200042244.

[92] M.K. Mondal, H.K. Balsora, P. Varshney, Progress and trends in $\mathrm{CO}_{2}$ capture/separation technologies: A review, Energy. 46 (2012) 431-441. doi:10.1016/j.energy.2012.08.006.

[93] H. Yang, Z. Xu, M. Fan, R. Gupta, R.B. Slimane, A.E. Bland, I. Wright, Progress in carbon dioxide separation and capture: A review, J. Environ. Sci. 20 (2008) 14-27. doi:10.1016/S1001-0742(08)60002-9. [94] A.A. Olajire, $\mathrm{CO}_{2}$ capture and separation technologies for end-of-pipe applications - A review, Energy. 35 (2010) 2610-2628. doi:10.1016/j.energy.2010.02.030.

[95] A. Brunetti, F. Scura, G. Barbieri, E. Drioli, Membrane technologies for $\mathrm{CO}_{2}$ separation, J. Membr. Sci. 359 (2010) 115-125. doi:10.1016/j.memsci.2009.11.040. 
[96] J.E. Bara, C.J. Gabriel, S. Lessmann, T.K. Carlisle, A. Finotello, D.L. Gin, R.D. Noble, Enhanced $\mathrm{CO}_{2}$ Separation Selectivity in Oligo(ethylene glycol) Functionalized Room-Temperature Ionic Liquids, Ind. Eng. Chem. Res. 46 (2007) 5380-5386. doi:10.1021/ie070437g.

[97] M. Vinoba, M. Bhagiyalakshmi, Y. Alqaheem, A.A. Alomair, A. Pérez, M.S. Rana, Recent progress of fillers in mixed matrix membranes for $\mathrm{CO}_{2}$ separation: A review, Sep. Purif. Technol. 188 (2017) 431-450. doi:10.1016/j.seppur.2017.07.051.

[98] M. Wang, Z. Wang, S. Zhao, J. Wang, S. Wang, Recent advances on mixed matrix membranes for $\mathrm{CO}_{2}$ separation, Chin. J. Chem. Eng. 25 (2017) 1581-1597. doi:10.1016/j.cjche.2017.07.006.

[99] J. Xu, H. Wu, Z. Wang, Z. Qiao, S. Zhao, J. Wang, Recent advances on the membrane processes for $\mathrm{CO}_{2}$ separation, Chin. J. Chem. Eng. 26 (2018) 2280-2291. doi:10.1016/j.cjche.2018.08.020.

[100] J.K. Adewole, A.L. Ahmad, S. Ismail, C.P. Leo, Current challenges in membrane separation of $\mathrm{CO}_{2}$ from natural gas: A review, Int. J. Greenh. Gas Control. 17 (2013) 46-65. doi:10.1016/j.ijggc.2013.04.012. [101] C. Song, Q. Liu, N. Ji, S. Deng, J. Zhao, Y. Li, Y. Song, H. Li, Alternative pathways for efficient $\mathrm{CO}_{2}$ capture by hybrid processes-A review, Renew. Sustain. Energy Rev. 82 (2018) 215-231. doi:10.1016/j.rser.2017.09.040.

[102] A. Eslamimanesh, A.H. Mohammadi, D. Richon, P. Naidoo, D. Ramjugernath, Application of gas hydrate formation in separation processes: A review of experimental studies, J. Chem. Thermodyn. 46 (2012) 62-71. doi:10.1016/j.jct.2011.10.006.

[103] C. Castel, E. Favre, Membrane separations and energy efficiency, J. Membr. Sci. 548 (2018) 345-357. doi:10.1016/j.memsci.2017.11.035.

[104] M.G. Buonomenna, J. Bae, Membrane processes and renewable energies, Renew. Sustain. Energy Rev. 43 (2015) 1343-1398. doi:10.1016/j.rser.2014.11.091.

[105] X. Cheng, F. Pan, M. Wang, W. Li, Y. Song, G. Liu, H. Yang, B. Gao, H. Wu, Z. Jiang, Hybrid membranes for pervaporation separations, J. Membr. Sci. 541 (2017) 329-346. doi:10.1016/j.memsci.2017.07.009.

[106] A. Jordan, N. Gathergood, Biodegradation of ionic liquids - a critical review, Chem. Soc. Rev. 44 (2015) 8200-8237. doi:10.1039/C5CS00444F.

[107] M. Amde, J.-F. Liu, L. Pang, Environmental Application, Fate, Effects, and Concerns of Ionic Liquids: A Review, Environ. Sci. Technol. 49 (2015) 12611-12627. doi:10.1021/acs.est.5b03123.

[108] K. Ghandi, A Review of Ionic Liquids, Their Limits and Applications, Green Sustain. Chem. 04 (2014) 44-53. doi:10.4236/gsc.2014.41008.

[109] M. Díaz, A. Ortiz, I. Ortiz, Progress in the use of ionic liquids as electrolyte membranes in fuel cells, J. Membr. Sci. 469 (2014) 379-396. doi:10.1016/j.memsci.2014.06.033.

[110] I. Osada, H. de Vries, B. Scrosati, S. Passerini, Ionic-Liquid-Based Polymer Electrolytes for Battery Applications, Angew. Chem. Int. Ed. 55 (2015) 500-513. doi:10.1002/anie.201504971.

[111] K. Yin, Z. Zhang, X. Li, L. Yang, K. Tachibana, S. Hirano, Polymer electrolytes based on dicationic polymeric ionic liquids: application in lithium metal batteries, J. Mater. Chem. A. 3 (2015) 170-178. doi:10.1039/C4TA05106H.

[112] D. Kasprzak, I. Stępniak, M. Galiński, Acetate- and lactate-based ionic liquids: Synthesis, characterisation and electrochemical properties, J. Mol. Liq. 264 (2018) 233-241. doi:10.1016/j.molliq.2018.05.059.

[113] J.C. Varela, K. Sankar, A. Hino, X. Lin, W. Chang, D. Coker, M. Grinstaff, Piperidinium ionic liquids as electrolyte solvents for sustained high temperature supercapacitor operation, Chem. Commun. 54 (2018) 5590-5593. doi:10.1039/C8CC01093E. 
[114] C.G. Yoo, Y. Pu, A.J. Ragauskas, Ionic liquids: Promising green solvents for lignocellulosic biomass utilization, Curr. Opin. Green Sustain. Chem. 5 (2017) 5-11. doi:10.1016/j.cogsc.2017.03.003.

[115] C. Dai, J. Zhang, C. Huang, Z. Lei, Ionic Liquids in Selective Oxidation: Catalysts and Solvents, Chem. Rev. 117 (2017) 6929-6983. doi:10.1021/acs.chemrev.7b00030.

[116] H. Guo, X. Qi, Y. Hiraga, T.M. Aida, R.L. Smith, Efficient conversion of fructose into 5ethoxymethylfurfural with hydrogen sulfate ionic liquids as co-solvent and catalyst, Chem. Eng. J. 314 (2017) 508-514. doi:10.1016/j.cej.2016.12.008.

[117] S. Sarmad, J.-P. Mikkola, X. Ji, Carbon Dioxide Capture with Ionic Liquids and Deep Eutectic Solvents: A New Generation of Sorbents, ChemSusChem. 10 (2017) 324-352. doi:10.1002/cssc.201600987.

[118] R.L. Vekariya, A review of ionic liquids: Applications towards catalytic organic transformations, J. Mol. Liq. 227 (2017) 44-60. doi:10.1016/j.molliq.2016.11.123.

[119] Y. Qiao, W. Ma, N. Theyssen, C. Chen, Z. Hou, Temperature-Responsive Ionic Liquids: Fundamental Behaviors and Catalytic Applications, Chem. Rev. 117 (2017) 6881-6928. doi:10.1021/acs.chemrev.6b00652. [120] S. Platzer, M. Kar, R. Leyma, S. Chib, A. Roller, F. Jirsa, R. Krachler, D.R. MacFarlane, W. Kandioller, B.K. Keppler, Task-specific thioglycolate ionic liquids for heavy metal extraction: Synthesis, extraction efficacies and recycling properties, J. Hazard. Mater. 324 (2017) 241-249. doi:10.1016/j.jhazmat.2016.10.054.

[121] Y. Ren, J. Zhang, J. Guo, F. Chen, F. Yan, Porous Poly(Ionic Liquid) Membranes as Efficient and Recyclable Absorbents for Heavy Metal Ions, Macromol. Rapid Commun. 38 (2017) 1700151. doi:10.1002/marc.201700151.

[122] J. de Riva, J. Suarez-Reyes, D. Moreno, I. Díaz, V. Ferro, J. Palomar, Ionic liquids for post-combustion $\mathrm{CO}_{2}$ capture by physical absorption: Thermodynamic, kinetic and process analysis, Int. J. Greenh. Gas Control. 61 (2017) 61-70. doi:10.1016/j.ijggc.2017.03.019.

[123] K.E. Gutowski, Industrial uses and applications of ionic liquids, Phys. Sci. Rev. 3 (2018). doi:10.1515/psr-2017-0191.

[124] I.B. Grillo, S. Einloft, M. Seferin, Multivariate Statistical Evaluation of Ionic Liquids Features for $\mathrm{CO}_{2}$ Capture, Energy Procedia. 114 (2017) 86-94. doi:10.1016/j.egypro.2017.03.1151.

[125] A. Baghban, A.H. Mohammadi, M.S. Taleghani, Rigorous modeling of $\mathrm{CO}_{2}$ equilibrium absorption in ionic liquids, Int. J. Greenh. Gas Control. 58 (2017) 19-41. doi:10.1016/j.ijggc.2016.12.009.

[126] A. Faghihi-Zarandi, H. Shirkhanloo, C. Jamshidzadeh, A new method for removal of hazardous toluene vapor from air based on ionic liquid-phase adsorbent, Int. J. Environ. Sci. Technol. (2018). doi:10.1007/s13762-018-1975-5.

[127] A.S.R. Castillo, S. Guihéneuf, P.-F. Biard, L. Paquin, A. Amrane, A. Couvert, Physicochemical properties of some hydrophobic room-temperature ionic liquids applied to volatile organic compounds biodegradation processes, J. Chem. Technol. Biotechnol. 93 (2018) 215-223. doi:10.1002/jctb.5343.

[128] Z. Chen, L. Yu, D. Zhang, K. Yang, E. Duan, Absorption of methylbenzene in 1-butyl-3methylimidazolium ionic liquids, Int. J. Mater. Prod. Technol. 55 (2017) 368-380. doi:10.1504/IJMPT.2017.087057.

[129] V.H. Jadhav, J.G. Kim, S.H. Park, D.W. Kim, Task-specific hexaethylene glycol bridged di-cationic ionic liquids as catalysts for nucleophilic fluorination using potassium fluoride, Chem. Eng. J. 308 (2017) 664-668. doi:10.1016/j.cej.2016.09.118.

[130] S.K. Patil, S.A. Patil, M.M. Vadiyar, D.V. Awale, A.S. Sartape, L.S. Walekar, G.B. Kolekar, U.V. Ghorpade, J.H. Kim, S.S. Kolekar, Tailor-made dicationic ionic liquid as a fluorescent sensor for detection of hydroquinone and catechol, J. Mol. Liq. 244 (2017) 39-45. doi:10.1016/j.molliq.2017.08.119. 
[131] S.P.F. Costa, A.M.O. Azevedo, P.C.A.G. Pinto, M.L.M.F.S. Saraiva, Environmental Impact of Ionic Liquids: Recent Advances in (Eco)toxicology and (Bio)degradability, ChemSusChem. 10 (2017) 2321-2347. doi:10.1002/cssc.201700261.

[132] T.E. Sintra, M. Nasirpour, F. Siopa, A.A. Rosatella, F. Gonçalves, J.A.P. Coutinho, C.A.M. Afonso, S.P.M. Ventura, Ecotoxicological evaluation of magnetic ionic liquids, Ecotoxicol. Environ. Saf. 143 (2017) 315-321. doi:10.1016/j.ecoenv.2017.05.034.

[133] M. Sydow, M. Owsianiak, G. Framski, M. Woźniak-Karczewska, A. Piotrowska-Cyplik, Ł. Ławniczak, A. Szulc, A. Zgoła-Grześkowiak, H.J. Heipieper, Ł. Chrzanowski, Biodiversity of soil bacteria exposed to sub-lethal concentrations of phosphonium-based ionic liquids: Effects of toxicity and biodegradation, Ecotoxicol. Environ. Saf. 147 (2018) 157-164. doi:10.1016/j.ecoenv.2017.08.026.

[134] K. Bittermann, K.-U. Goss, Assessing the toxicity of ionic liquids - Application of the critical membrane concentration approach, Chemosphere. $183 \quad$ (2017) 410-418. doi:10.1016/j.chemosphere.2017.05.097.

[135] M. Grzonkowska, A. Sosnowska, M. Barycki, A. Rybinska, T. Puzyn, How the structure of ionic liquid affects its toxicity to Vibrio fischeri?, Chemosphere. 159 (2016) 199-207. doi:10.1016/j.chemosphere.2016.06.004.

[136] K.S. Egorova, V.P. Ananikov, Fundamental importance of ionic interactions in the liquid phase: A review of recent studies of ionic liquids in biomedical and pharmaceutical applications, J. Mol. Liq. 272 (2018) 271-300. doi:10.1016/j.molliq.2018.09.025.

[137] R. Hayes, G.G. Warr, R. Atkin, Structure and Nanostructure in Ionic Liquids, Chem. Rev. 115 (2015) 6357-6426. doi:10.1021/cr500411q.

[138] Y. Ma, Y. Liu, H. Su, L. Wang, J. Zhang, Relationship between hydrogen bond and viscosity for a series of pyridinium ionic liquids: Molecular dynamics and quantum chemistry, J. Mol. Liq. 255 (2018) 176-184. doi:10.1016/j.molliq.2018.01.121.

[139] X. Liu, X. Yao, Y. Wang, S. Zhang, Mesoscale structures and mechanisms in ionic liquids, Particuology. (2019). doi:10.1016/j.partic.2018.08.003.

[140] K.N. Marsh, J.A. Boxall, R. Lichtenthaler, Room temperature ionic liquids and their mixtures-a review, Fluid Phase Equilibria. 219 (2004) 93-98. doi:10.1016/j.fluid.2004.02.003.

[141] F. Béguin, V. Presser, A. Balducci, E. Frackowiak, Carbons and Electrolytes for Advanced Supercapacitors, Adv. Mater. 26 (2014) 2219-2251. doi:10.1002/adma.201304137.

[142] T. Welton, Room-Temperature Ionic Liquids. Solvents for Synthesis and Catalysis, Chem. Rev. 99 (1999) 2071-2084. doi:10.1021/cr980032t.

[143] K.R. Seddon, A. Stark, M.-J. Torres, Influence of chloride, water, and organic solvents on the physical properties of ionic liquids, Pure Appl. Chem. 72 (2000) 2275-2287. doi:10.1351/pac200072122275.

[144] P.A. Hunt, Why Does a Reduction in Hydrogen Bonding Lead to an Increase in Viscosity for the 1Butyl-2,3-dimethyl-imidazolium-Based Ionic Liquids?, J. Phys. Chem. B. 111 (2007) 4844-4853. doi:10.1021/jp067182p.

[145] F. Endres, S.Z.E. Abedin, Air and water stable ionic liquids in physical chemistry, Phys. Chem. Chem. Phys. 8 (2006) 2101-2116. doi:10.1039/B600519P.

[146] A. Noda, K. Hayamizu, M. Watanabe, Pulsed-Gradient Spin-Echo 1H and 19F NMR Ionic Diffusion Coefficient, Viscosity, and Ionic Conductivity of Non-Chloroaluminate Room-Temperature Ionic Liquids, J. Phys. Chem. B. 105 (2001) 4603-4610. doi:10.1021/jp004132q.

[147] S.N. Baker, G.A. Baker, F.V. Bright, Temperature-dependent microscopic solvent properties of 'dry' and 'wet' 1-butyl-3-methylimidazolium hexafluorophosphate: correlation with ET(30) and Kamlet-Taft 
polarity scales, Green Chem. 4 (2002) 165-169. doi:10.1039/B111285F.

[148] X. Wang, M. Jin, Y. Li, L. Zhao, The influence of various ionic liquids on the properties of SPEEK membrane doped with mesoporous silica, Electrochimica Acta. 257 (2017) 290-300. doi:10.1016/j.electacta.2017.10.098.

[149] H. Wu, F. Shen, J. Wang, Y. Wan, Membrane fouling in vacuum membrane distillation for ionic liquid recycling: Interaction energy analysis with the XDLVO approach, J. Membr. Sci. 550 (2018) 436-447. doi:10.1016/j.memsci.2018.01.018.

[150] M. Fallanza, A. Ortiz, D. Gorri, I. Ortiz, Comparison of Reactive Membranes Containing ILs in the Separation of Gaseous Olefin-Paraffin Mixtures, Procedia Eng. Complete (2012) 326-327. doi:10.1016/j.proeng.2012.08.404.

[151] J.I. Santos, A.M.M. Gonçalves, J.L. Pereira, B.F.H.T. Figueiredo, F.A. e Silva, J. a. P. Coutinho, S.P.M. Ventura, F. Gonçalves, Environmental safety of cholinium-based ionic liquids: assessing structureecotoxicity relationships, Green Chem. 17 (2015) 4657-4668. doi:10.1039/C5GC01129A.

[152] K.S. Egorova, E.G. Gordeev, V.P. Ananikov, Biological Activity of Ionic Liquids and Their Application in Pharmaceutics and Medicine, (2017). doi:10.1021/acs.chemrev.6b00562.

[153] S.P.M. Ventura, F.A. e Silva, A.M.M. Gonçalves, J.L. Pereira, F. Gonçalves, J.A.P. Coutinho, Ecotoxicity analysis of cholinium-based ionic liquids to Vibrio fischeri marine bacteria, Ecotoxicol. Environ. Saf. 102 (2014) 48-54. doi:10.1016/j.ecoenv.2014.01.003.

[154] M. Cvjetko Bubalo, K. Radošević, I. Radojčić Redovniković, J. Halambek, V. Gaurina Srček, A brief overview of the potential environmental hazards of ionic liquids, Ecotoxicol. Environ. Saf. 99 (2014) 1-12. doi:10.1016/j.ecoenv.2013.10.019.

[155] T.P.T. Pham, C.-W. Cho, Y.-S. Yun, Structural effects of ionic liquids on microalgal growth inhibition and microbial degradation, Environ. Sci. Pollut. Res. 23 (2016) 4294-4300. doi:10.1007/s11356-015-52878 .

[156] E. Santos, J. Albo, A. Irabien, Acetate based Supported Ionic Liquid Membranes (SILMs) for $\mathrm{CO}_{2}$ separation: Influence of the temperature, J. Membr. Sci. 452 (2014) 277-283. doi:10.1016/j.memsci.2013.10.024.

[157] Y. Ban, Z. Li, Y. Li, Y. Peng, H. Jin, W. Jiao, A. Guo, P. Wang, Q. Yang, C. Zhong, W. Yang, Confinement of Ionic Liquids in Nanocages: Tailoring the Molecular Sieving Properties of ZIF-8 for Membrane-Based $\mathrm{CO}_{2}$ Capture, Angew. Chem. Int. Ed. 54 (2015) 15483-15487. doi:10.1002/anie.201505508.

[158] L.C. Tomé, D.J.S. Patinha, R. Ferreira, H. Garcia, C. Silva Pereira, C.S.R. Freire, L.P.N. Rebelo, I.M. Marrucho, Cholinium-based Supported Ionic Liquid Membranes: A Sustainable Route for Carbon Dioxide Separation, ChemSusChem. 7 (2014) 110-113. doi:10.1002/cssc.201300613.

[159] Y. Oh, D.L. Armstrong, C. Finnerty, S. Zheng, M. Hu, A. Torrents, B. Mi, Understanding the pHresponsive behavior of graphene oxide membrane in removing ions and organic micropollulants, J. Membr. Sci. 541 (2017) 235-243. doi:10.1016/j.memsci.2017.07.005.

[160] S.D. Hojniak, I.P. Silverwood, A.L. Khan, I.F.J. Vankelecom, W. Dehaen, S.G. Kazarian, K. Binnemans, Highly Selective Separation of Carbon Dioxide from Nitrogen and Methane by Nitrile/GlycolDifunctionalized Ionic Liquids in Supported Ionic Liquid Membranes (SILMs), (2014). doi:10.1021/jp503259b.

[161] M.-A. Pizzoccaro-Zilamy, M. Drobek, E. Petit, C. Totée, G. Silly, G. Guerrero, M.G. Cowan, A. Ayral, A. Julbe, Initial Steps toward the Development of Grafted Ionic Liquid Membranes for the Selective Transport of $\mathrm{CO}_{2}$, Ind. Eng. Chem. Res. (2018). doi:10.1021/acs.iecr.8b02466. 
[162] F. Hassan Hassan Abdellatif, J. Babin, C. Arnal-Herault, L. David, A. Jonquieres, Grafting cellulose acetate with ionic liquids for biofuel purification membranes : Influence of the anion, Carbohydr. Polym. 196 (2018) 176-186. doi:10.1016/j.carbpol.2018.05.008.

[163] M. Althuluth, J.P. Overbeek, H.J. van Wees, L.F. Zubeir, W.G. Haije, A. Berrouk, C.J. Peters, M.C. Kroon, Natural gas purification using supported ionic liquid membrane, J. Membr. Sci. 484 (2015) 80-86. doi:10.1016/j.memsci.2015.02.033.

[164] L.J. Lozano, C. Godínez, A.P. de los Ríos, F.J. Hernández-Fernández, S. Sánchez-Segado, F.J. Alguacil, Recent advances in supported ionic liquid membrane technology, J. Membr. Sci. 376 (2011) 1-14. doi:10.1016/j.memsci.2011.03.036.

[165] L. Ansaloni, J.R. Nykaza, Y. Ye, Y.A. Elabd, M. Giacinti Baschetti, Influence of water vapor on the gas permeability of polymerized ionic liquids membranes, J. Membr. Sci. 487 (2015) 199-208. doi:10.1016/j.memsci.2015.03.065.

[166] F. Sullivan-González, P. Scovazzo, R. Amos, S.-K. Bae, Hydrogen-bond acceptance's role in designing room temperature ionic liquid (RTIL) membranes for gas dehumidification, part I: Impacts on permeance and selectivity, J. Membr. Sci. 533 (2017) 190-200. doi:10.1016/j.memsci.2017.03.026.

[167] A. Kudasheva, T. Kamiya, Y. Hirota, A. Ito, Dehumidification of air using liquid membranes with ionic liquids, J. Membr. Sci. 499 (2016) 379-385. doi:10.1016/j.memsci.2015.10.069.

[168] J. Wang, J. Luo, S. Feng, H. Li, Y. Wan, X. Zhang, Recent development of ionic liquid membranes, Green Energy Environ. 1 (2016) 43-61. doi:10.1016/j.gee.2016.05.002.

[169] R.D. Noble, D.L. Gin, Perspective on ionic liquids and ionic liquid membranes, J. Membr. Sci. 369 (2011) 1-4. doi:10.1016/j.memsci.2010.11.075.

[170] L.C. Tomé, I.M. Marrucho, Ionic liquid-based materials: a platform to design engineered $\mathrm{CO}_{2}$ separation membranes, Chem. Soc. Rev. 45 (2016) 2785-2824. doi:10.1039/C5CS00510H.

[171] L. Liang, Q. Gan, P. Nancarrow, Composite ionic liquid and polymer membranes for gas separation at elevated temperatures, J. Membr. Sci. 450 (2014) 407-417. doi:10.1016/j.memsci.2013.09.033.

[172] D.S. Karousos, A.I. Labropoulos, O. Tzialla, K. Papadokostaki, M. Gjoka, K.L. Stefanopoulos, K.G. Beltsios, B. Iliev, T.J.S. Schubert, G.E. Romanos, Effect of a cyclic heating process on the $\mathrm{CO}_{2} / \mathrm{N}_{2}$ separation performance and structure of a ceramic nanoporous membrane supporting the ionic liquid 1-methyl-3octylimidazolium tricyanomethanide, Sep. Purif. Technol. $200 \quad$ (2018) 11-22. doi:10.1016/j.seppur.2018.02.013.

[173] R. Kreiter, J.P. Overbeek, L.A. Correia, J.F. Vente, Pressure resistance of thin ionic liquid membranes using tailored ceramic supports, J. Membr. Sci. 370 (2011) 175-178. doi:10.1016/j.memsci.2010.12.024. [174] S.-H. Chai, P.F. Fulvio, P.C. Hillesheim, Z.-A. Qiao, S.M. Mahurin, S. Dai, "Brick-and-mortar" synthesis of free-standing mesoporous carbon nanocomposite membranes as supports of room temperature ionic liquids for $\mathrm{CO}_{2}-\mathrm{N}_{2}$ separation, J. Membr. Sci. 468 (2014) 73-80. doi:10.1016/j.memsci.2014.05.044. [175] A.P. de los Ríos, F.J. Hernández-Fernández, F. Tomás-Alonso, J.M. Palacios, D. Gómez, M. Rubio, G. Víllora, A SEM-EDX study of highly stable supported liquid membranes based on ionic liquids, J. Membr. Sci. 300 (2007) 88-94. doi:10.1016/j.memsci.2007.05.010.

[176] I. Cichowska-Kopczyńska, M. Joskowska, B. Debski, R. Aranowski, J. Hupka, Separation of toluene from gas phase using supported imidazolium ionic liquid membrane, J. Membr. Sci. 566 (2018) 367-373. doi:10.1016/j.memsci.2018.08.058.

[177] I. Cichowska-Kopczynska, M. Joskowska, R. Aranowski, Wetting processes in supported ionic liquid membranes technology, Physicochem. Probl. Miner. Process. (2014) 373--386. doi:10.5277/ppmp140131. [178] L. Gomez-Coma, A. Garea, J.C. Rouch, T. Savart, J.F. Lahitte, J.C. Remigy, A. Irabien, Membrane 
modules for $\mathrm{CO}_{2}$ capture based on PVDF hollow fibers with ionic liquids immobilized, J. Membr. Sci. 498 (2016) 218-226. doi:10.1016/j.memsci.2015.10.023.

[179] D.-H. Kim, I.-H. Baek, S.-U. Hong, H.-K. Lee, Study on immobilized liquid membrane using ionic liquid and PVDF hollow fiber as a support for $\mathrm{CO}_{2} / \mathrm{N}_{2}$ separation, J. Membr. Sci. 372 (2011) 346-354. doi:10.1016/j.memsci.2011.02.025.

[180] P. Cserjési, N. Nemestóthy, A. Vass, Z. Csanádi, K. Bélafi-Bakó, Study on gas separation by supported liquid membranes applying novel ionic liquids, Desalination. 245 (2009) 743-747. doi:10.1016/j.desal.2009.02.046.

[181] S. Hanioka, T. Maruyama, T. Sotani, M. Teramoto, H. Matsuyama, K. Nakashima, M. Hanaki, F. Kubota, M. Goto, $\mathrm{CO}_{2}$ separation facilitated by task-specific ionic liquids using a supported liquid membrane, J. Membr. Sci. 314 (2008) 1-4. doi:10.1016/j.memsci.2008.01.029.

[182] F. Korminouri, M. Rahbari-Sisakht, T. Matsuura, A.F. Ismail, Surface modification of polysulfone hollow fiber membrane spun under different air-gap lengths for carbon dioxide absorption in membrane contactor system, Chem. Eng. J. 264 (2015) 453-461. doi:10.1016/j.cej.2014.11.110.

[183] S.-C. Lu, A.L. Khan, I.F.J. Vankelecom, Polysulfone-ionic liquid based membranes for $\mathrm{CO}_{2} / \mathrm{N}_{2}$ separation with tunable porous surface features, J. Membr. Sci. 518 (2016) 10-20. doi:10.1016/j.memsci.2016.06.031.

[184] J. Ilconich, C. Myers, H. Pennline, D. Luebke, Experimental investigation of the permeability and selectivity of supported ionic liquid membranes for $\mathrm{CO}_{2} / \mathrm{He}$ separation at temperatures up to $125{ }^{\circ} \mathrm{C}$, J. Membr. Sci. 298 (2007) 41-47. doi:10.1016/j.memsci.2007.03.056.

[185] A. Alkhouzaam, M. Khraisheh, M. Atilhan, S.A. Al-Muhtaseb, L. Qi, D. Rooney, High-pressure $\mathrm{CO}_{2} / \mathrm{N}_{2}$ and $\mathrm{CO}_{2} / \mathrm{CH}_{4}$ separation using dense polysulfone-supported ionic liquid membranes, J. Nat. Gas Sci. Eng. 36 (2016) 472-485. doi:10.1016/j.jngse.2016.10.061.

[186] J.J. Close, K. Farmer, S.S. Moganty, R.E. Baltus, $\mathrm{CO}_{2} / \mathrm{N}_{2}$ separations using nanoporous aluminasupported ionic liquid membranes: Effect of the support on separation performance, J. Membr. Sci. 390-391 (2012) 201-210. doi:10.1016/j.memsci.2011.11.037.

[187] K. Fatyeyeva, S. Rogalsky, O. Tarasyuk, C. Chappey, S. Marais, Vapour sorption and permeation behaviour of supported ionic liquid membranes: Application for organic solvent/water separation, React. Funct. Polym. 130 (2018) 16-28. doi:10.1016/j.reactfunctpolym.2018.05.007.

[188] R. Fortunato, C.A.M. Afonso, M.A.M. Reis, J.G. Crespo, Supported liquid membranes using ionic liquids: study of stability and transport mechanisms, J. Membr. Sci. 242 (2004) 197-209. doi:10.1016/j.memsci.2003.07.028.

[189] F.J. Hernández-Fernández, A.P. de los Ríos, F. Tomás-Alonso, J.M. Palacios, G. Víllora, Preparation of supported ionic liquid membranes: Influence of the ionic liquid immobilization method on their operational stability, J. Membr. Sci. 341 (2009) 172-177. doi:10.1016/j.memsci.2009.06.003.

[190] A. Dahi, K. Fatyeyeva, D. Langevin, C. Chappey, F. Poncin-Epaillard, S. Marais, Effect of cold plasma surface treatment on the properties of supported ionic liquid membranes, Sep. Purif. Technol. 187 (2017) 127-136. doi:10.1016/j.seppur.2017.05.055.

[191] A. Dahi, K. Fatyeyeva, D. Langevin, C. Chappey, S.P. Rogalsky, O.P. Tarasyuk, A. Benamor, S. Marais, Supported ionic liquid membranes for water and volatile organic compounds separation: Sorption and permeation properties, J. Membr. Sci. 458 (2014) 164-178. doi:10.1016/j.memsci.2014.01.031.

[192] R. Martínez-Palou, N.V. Likhanova, O. Olivares-Xometl, Supported ionic liquid membranes for separations of gases and liquids: an overview, Pet. Chem. 54 (2014) 595-607. doi:10.1134/S0965544114080106. 
[193] T. Uragami, E. Fukuyama, T. Miyata, Selective removal of dilute benzene from water by poly(methyl methacrylate)-graft-poly(dimethylsiloxane) membranes containing hydrophobic ionic liquid by pervaporation, J. Membr. Sci. 510 (2016) 131-140. doi:10.1016/j.memsci.2016.01.057.

[194] J.E. Bara, C.J. Gabriel, T.K. Carlisle, D.E. Camper, A. Finotello, D.L. Gin, R.D. Noble, Gas separations in fluoroalkyl-functionalized room-temperature ionic liquids using supported liquid membranes, Chem. Eng. J. 147 (2009) 43-50. doi:10.1016/j.cej.2008.11.021.

[195] F.J. Hernández-Fernández, A.P. de los Ríos, F. Tomás-Alonso, D. Gómez, G. Víllora, Improvement in the separation efficiency of transesterification reaction compounds by the use of supported ionic liquid membranes based on the dicyanamide anion, Desalination. 244 (2009) 122-129. doi:10.1016/j.desal.2008.04.041.

[196] A.P. de los Ríos, F.J. Hernández-Fernández, H. Presa, D. Gómez, G. Víllora, Tailoring supported ionic liquid membranes for the selective separation of transesterification reaction compounds, J. Membr. Sci. 328 (2009) 81-85. doi:10.1016/j.memsci.2008.11.041.

[197] A.P. de los Ríos, F.J. Hernández-Fernández, M. Rubio, D. Gómez, G. Víllora, Highly selective transport of transesterification reaction compounds through supported liquid membranes containing ionic liquids based on the tetrafluoroborate anion, Desalination. 250 (2010) 101-104. doi:10.1016/j.desal.2009.06.039.

[198] A.P. de los Ríos, F.J. Hernández-Fernández, M. Rubio, F. Tomás-Alonso, D. Gómez, G. Víllora, Prediction of the selectivity in the recovery of transesterification reaction products using supported liquid membranes based on ionic liquids, J. Membr. Sci. 307 (2008) 225-232. doi:10.1016/j.memsci.2007.09.019. [199] T.K. Carlisle, G.D. Nicodemus, D.L. Gin, R.D. Noble, $\mathrm{CO}_{2} /$ light gas separation performance of crosslinked poly(vinylimidazolium) gel membranes as a function of ionic liquid loading and cross-linker content, J. Membr. Sci. 397-398 (2012) 24-37. doi:10.1016/j.memsci.2012.01.006.

[200] C. Myers, H. Pennline, D. Luebke, J. Ilconich, J.K. Dixon, E.J. Maginn, J.F. Brennecke, High temperature separation of carbon dioxide/hydrogen mixtures using facilitated supported ionic liquid membranes, J. Membr. Sci. 322 (2008) 28-31. doi:10.1016/j.memsci.2008.04.062.

[201] K. Huang, X.-M. Zhang, Y.-X. Li, Y.-T. Wu, X.-B. Hu, Facilitated separation of $\mathrm{CO}_{2}$ and $\mathrm{SO}_{2}$ through supported liquid membranes using carboxylate-based ionic liquids, J. Membr. Sci. 471 (2014) 227-236. doi:10.1016/j.memsci.2014.08.022.

[202] D.S. Karousos, A.I. Labropoulos, A. Sapalidis, N.K. Kanellopoulos, B. Iliev, T.J.S. Schubert, G.E. Romanos, Nanoporous ceramic supported ionic liquid membranes for $\mathrm{CO} 2$ and $\mathrm{SO} 2$ removal from flue gas, Chem. Eng. J. 313 (2017) 777-790. doi:10.1016/j.cej.2016.11.005.

[203] W.G. Lee, S.W. Kang, Highly selective poly(ethylene oxide)/ionic liquid electrolyte membranes containing $\mathrm{CrO}_{3}$ for $\mathrm{CO}_{2} / \mathrm{N}_{2}$ separation, Chem. Eng. J. 356 (2019) 312-317. doi:10.1016/j.cej.2018.09.049. [204] J.A. Schott, C.-L. Do-Thanh, S.M. Mahurin, Z. Tian, N.C. Onishi, D. Jiang, S. Dai, Supported bicyclic amidine ionic liquids as a potential $\mathrm{CO}_{2} / \mathrm{N}_{2}$ separation medium, J. Membr. Sci. 565 (2018) 203-212. doi:10.1016/j.memsci.2018.08.012.

[205] J. Grünauer, S. Shishatskiy, C. Abetz, V. Abetz, V. Filiz, Ionic liquids supported by isoporous membranes for $\mathrm{CO}_{2} / \mathrm{N}_{2}$ gas separation applications, J. Membr. Sci. 494 (2015) 224-233. doi:10.1016/j.memsci.2015.07.054.

[206] C. Dai, Z. Lei, B. Chen, Gas solubility in long-chain imidazolium-based ionic liquids, AIChE J. 63 (2017) 1792-1798. doi:10.1002/aic.15711.

[207] R.P. Matthews, T. Welton, P.A. Hunt, Competitive pi interactions and hydrogen bonding within imidazolium ionic liquids, Phys. Chem. Chem. Phys. 16 (2014) 3238-3253. doi:10.1039/C3CP54672A.

[208] D. Camper, J. Bara, C. Koval, R. Noble, Bulk-Fluid Solubility and Membrane Feasibility of Rmim- 
Based Room-Temperature Ionic Liquids, Ind. Eng. Chem. Res. 45 (2006) 6279-6283. doi:10.1021/ie060177n.

[209] M.Y.M. Abdelrahim, C.F. Martins, L.A. Neves, C. Capasso, C.T. Supuran, I.M. Coelhoso, J.G. Crespo, M. Barboiu, Supported ionic liquid membranes immobilized with carbonic anhydrases for $\mathrm{CO}_{2}$ transport at high temperatures, J. Membr. Sci. 528 (2017) 225-230. doi:10.1016/j.memsci.2017.01.033.

[210] T. Fan, W. Xie, X. Ji, C. Liu, X. Feng, X. Lu, $\mathrm{CO}_{2} / \mathrm{N}_{2}$ separation using supported ionic liquid membranes with green and cost-effective [Choline][Pro]/PEG200 mixtures, Chin. J. Chem. Eng. 24 (2016) 1513-1521. doi:10.1016/j.cjche.2016.03.006.

[211] C.E. Sánchez Fuentes, D. Guzmán-Lucero, M. Torres-Rodriguez, N.V. Likhanova, J.N. Bolaños, O. Olivares-Xometl, I.V. Lijanova, $\mathrm{CO}_{2} / \mathrm{N}_{2}$ separation using alumina supported membranes based on new functionalized ionic liquids, Sep. Purif. Technol. 182 (2017) 59-68. doi:10.1016/j.seppur.2017.03.031.

[212] J. Albo, T. Yoshioka, T. Tsuru, Porous $\mathrm{Al}_{2} \mathrm{O}_{3} / \mathrm{TiO}_{2}$ tubes in combination with 1-ethyl-3methylimidazolium acetate ionic liquid for $\mathrm{CO}_{2} / \mathrm{N}_{2}$ separation, Sep. Purif. Technol. 122 (2014) 440-448. doi:10.1016/j.seppur.2013.11.024.

[213] R.E. Baltus, R.M. Counce, B.H. Culbertson, H. Luo, D.W. DePaoli, S. Dai, D.C. Duckworth, Examination of the Potential of Ionic Liquids for Gas Separations, Sep. Sci. Technol. 40 (2005) 525-541. doi:10.1081/SS-200042513.

[214] S.M. Mahurin, T. Dai, J.S. Yeary, H. Luo, S. Dai, Benzyl-Functionalized Room Temperature Ionic Liquids for $\mathrm{CO}_{2} / \mathrm{N}_{2}$ Separation, Ind. Eng. Chem. Res. 50 (2011) 14061-14069. doi:10.1021/ie201428k.

[215] X.-M. Zhang, Z.-H. Tu, H. Li, L. Li, Y.-T. Wu, X.-B. Hu, Supported protic-ionic-liquid membranes with facilitated transport mechanism for the selective separation of $\mathrm{CO}_{2}$, J. Membr. Sci. 527 (2017) 60-67. doi:10.1016/j.memsci.2017.01.006.

[216] X. Zhang, Z. Tu, H. Li, K. Huang, X. Hu, Y. Wu, D.R. MacFarlane, Selective separation of H2S and $\mathrm{CO}_{2}$ from $\mathrm{CH}_{4}$ by supported ionic liquid membranes, J. Membr. Sci. 543 (2017) 282-287. doi:10.1016/j.memsci.2017.08.033.

[217] B. Liu, R. Zhou, N. Bu, Q. Wang, S. Zhong, B. Wang, K. Hidetoshi, Room-temperature ionic liquids modified zeolite SSZ-13 membranes for $\mathrm{CO}_{2} / \mathrm{CH}_{4}$ separation, J. Membr. Sci. 524 (2017) 12-19. doi:10.1016/j.memsci.2016.11.004.

[218] A. Ilyas, N. Muhammad, M.A. Gilani, K. Ayub, I.F.J. Vankelecom, A.L. Khan, Supported protic ionic liquid membrane based on 3-(trimethoxysilyl)propan-1-aminium acetate for the highly selective separation of $\mathrm{CO}_{2}$, J. Membr. Sci. 543 (2017) 301-309. doi:10.1016/j.memsci.2017.08.071.

[219] P. Scovazzo, J. Kieft, D. Finan, C. Koval, D. Dubois, R. Noble, Gas separations using nonhexafluorophosphate $\left[\mathrm{PF}_{6}\right]^{-}$anion supported ionic liquid membranes, J. Membr. Sci. 238 (2004) 57-63. doi:10.1016/j.memsci.2004.02.033.

[220] L.C. Tomé, D.J.S. Patinha, C.S.R. Freire, L.P.N. Rebelo, I.M. Marrucho, $\mathrm{CO}_{2}$ separation applying ionic liquid mixtures: the effect of mixing different anions on gas permeation through supported ionic liquid membranes, RSC Adv. 3 (2013) 12220-12229. doi:10.1039/C3RA41269E.

[221] N. Shahkaramipour, M. Adibi, A.A. Seifkordi, Y. Fazli, Separation of $\mathrm{CO}_{2} / \mathrm{CH}_{4}$ through aluminasupported geminal ionic liquid membranes, J. Membr. Sci. 455 (2014) 229-235. doi:10.1016/j.memsci.2013.12.039.

[222] M.S. Shannon, J.M. Tedstone, S.P.O. Danielsen, M.S. Hindman, A.C. Irvin, J.E. Bara, Free Volume as the Basis of Gas Solubility and Selectivity in Imidazolium-Based Ionic Liquids, (2012). doi:10.1021/ie202916e.

[223] D.D. Iarikov, P. Hacarlioglu, S.T. Oyama, Supported room temperature ionic liquid membranes for 
$\mathrm{CO}_{2} / \mathrm{CH}_{4}$ separation, Chem. Eng. J. 166 (2011) 401-406. doi:10.1016/j.cej.2010.10.060.

[224] S.P. Nunes, A.R. Behzad, K.-V. Peinemann, Self-assembled block copolymer membranes: From basic research to large-scale manufacturing, J. Mater. Res. 28 (2013) 2661-2665. doi:10.1557/jmr.2013.253. [225] Shalu, S.K. Chaurasia, R.K. Singh, S. Chandra, Thermal Stability, Complexing Behavior, and Ionic Transport of Polymeric Gel Membranes Based on Polymer PVdF-HFP and Ionic Liquid, [BMIM][BF 4 , J. Phys. Chem. B. 117 (2013) 897-906. doi:10.1021/jp307694q.

[226] J. Lu, F. Yan, J. Texter, Advanced applications of ionic liquids in polymer science, Prog. Polym. Sci. 34 (2009) 431-448. doi:10.1016/j.progpolymsci.2008.12.001.

[227] Z. Dai, R.D. Noble, D.L. Gin, X. Zhang, L. Deng, Combination of ionic liquids with membrane technology: A new approach for $\mathrm{CO}_{2}$ separation, J. Membr. Sci. 497 (2016) 1-20. doi:10.1016/j.memsci.2015.08.060.

[228] B. Sasikumar, G. Arthanareeswaran, A.F. Ismail, Recent progress in ionic liquid membranes for gas separation, J. Mol. Liq. 266 (2018) 330-341. doi:10.1016/j.molliq.2018.06.081.

[229] W. Fam, J. Mansouri, H. Li, V. Chen, Improving $\mathrm{CO}_{2}$ separation performance of thin film composite hollow fiber with Pebax®1657/ionic liquid gel membranes, J. Membr. Sci. 537 (2017) 54-68. doi:10.1016/j.memsci.2017.05.011.

[230] H.Z. Chen, P. Li, T.-S. Chung, PVDF/ionic liquid polymer blends with superior separation performance for removing $\mathrm{CO}_{2}$ from hydrogen and flue gas, Int. J. Hydrog. Energy. 37 (2012) 11796-11804. doi:10.1016/j.ijhydene.2012.05.111.

[231] H.A. Mannan, D.F. Mohshim, H. Mukhtar, T. Murugesan, Z. Man, M.A. Bustam, Synthesis, characterization, and $\mathrm{CO}_{2}$ separation performance of polyether sulfone/[EMIM][Tf $\left.2 \mathrm{~N}\right]$ ionic liquidpolymeric membranes (ILPMs), J. Ind. Eng. Chem. 54 (2017) 98-106. doi:10.1016/j.jiec.2017.05.022.

[232] Y. Qiu, J. Ren, D. Zhao, H. Li, M. Deng, Poly(amide-6-b-ethylene oxide)/[Bmim][Tf $\left.{ }_{2} \mathrm{~N}\right]$ blend membranes for carbon dioxide separation, J. Energy Chem. 25 (2016) 122-130. doi:10.1016/j.jechem.2015.10.009.

[233] T. Uragami, Y. Matsuoka, T. Miyata, Permeation and separation characteristics in removal of dilute volatile organic compounds from aqueous solutions through copolymer membranes consisted of poly(styrene) and poly(dimethylsiloxane) containing a hydrophobic ionic liquid by pervaporation, J. Membr. Sci. 506 (2016) 109-118. doi:10.1016/j.memsci.2016.01.031.

[234] Y. Cao, Y. Chen, L. Lu, Z. Xue, T. Mu, Water Sorption in Functionalized Ionic Liquids: Kinetics and Intermolecular Interactions, Ind. Eng. Chem. Res. 52 (2013) 2073-2083. doi:10.1021/ie302850z.

[235] Q.-G. Zhang, N.-N. Wang, S.-L. Wang, Z.-W. Yu, Hydrogen Bonding Behaviors of Binary Systems Containing the Ionic Liquid 1-Butyl-3-methylimidazolium Trifluoroacetate and Water/Methanol, J. Phys. Chem. B. 115 (2011) 11127-11136. doi:10.1021/jp204305g.

[236] J.M. Crosthwaite, S.N.V.K. Aki, E.J. Maginn, J.F. Brennecke, Liquid Phase Behavior of ImidazoliumBased Ionic Liquids with Alcohols, J. Phys. Chem. B. 108 (2004) 5113-5119. doi:10.1021/jp037774x.

[237] M. Jebur, A. Sengupta, Y.-H. Chiao, M. Kamaz, X. Qian, R. Wickramasinghe, Pi electron cloud mediated separation of aromatics using supported ionic liquid (SIL) membrane having antibacterial activity, J. Membr. Sci. 556 (2018) 1-11. doi:10.1016/j.memsci.2018.03.064.

[238] W. Chinpa, D. Quémener, E. Bèche, R. Jiraratananon, A. Deratani, Preparation of poly(etherimide) based ultrafiltration membrane with low fouling property by surface modification with poly(ethylene glycol), J. Membr. Sci. 365 (2010) 89-97. doi:10.1016/j.memsci.2010.08.040.

[239] L. Yan, J. Wang, Development of a new polymer membrane - PVB/PVDF blended membrane, Desalination. 281 (2011) 455-461. doi:10.1016/j.desal.2011.08.024. 
[240] M. Matsumoto, Y. Inomoto, K. Kondo, Selective separation of aromatic hydrocarbons through supported liquid membranes based on ionic liquids, J. Membr. Sci. 246 (2005) 77-81. doi:10.1016/j.memsci.2004.08.013.

[241] M. Chakraborty, D. Dobaria, P.A. Parikh, The Separation of Aromatic Hydrocarbons Through a Supported Ionic Liquid Membrane, Pet. Sci. Technol. 30 (2012) 2504-2516. doi:10.1080/10916466.2010.516618.

[242] T. Uragami, Y. Matsuoka, T. Miyata, Removal of Dilute Benzene in Water through Ionic Liquid/Poly(Vinyl Chloride) Membranes by Pervaporation, J. Membr. Sci. Res. 2 (2016) 20-25. doi:10.22079/jmsr.2016.15874.

[243] L. Morávková, O. Vopička, J. Vejražka, H. Vychodilová, Z. Sedláková, K. Friess, P. Izák, Vapour permeation and sorption in fluoropolymer gel membrane based on ionic liquid 1-ethyl-3-methylimidazolium bis(trifluoromethylsulphonyl)imide, Chem. Pap. 68 (2014) 1739-1746. doi:10.2478/s11696-014-0623-x.

[244] D.Y. Xing, N. Peng, T.-S. Chung, Investigation of unique interactions between cellulose acetate and ionic liquid [EMIM]SCN, and their influences on hollow fiber ultrafiltration membranes, J. Membr. Sci. 380 (2011) 87-97. doi:10.1016/j.memsci.2011.06.032.

[245] D.Y. Xing, N. Peng, T.-S. Chung, Formation of Cellulose Acetate Membranes via Phase Inversion Using Ionic Liquid, [BMIM]SCN, As the Solvent, Ind. Eng. Chem. Res. 49 (2010) 8761-8769. doi:10.1021/ie1007085.

[246] P. Bakonyi, N. Nemestóthy, K. Bélafi-Bakó, Biohydrogen purification by membranes: An overview on the operational conditions affecting the performance of non-porous, polymeric and ionic liquid based gas separation membranes, Int. J. Hydrog. Energy. 38 (2013) 9673-9687. doi:10.1016/j.ijhydene.2013.05.158.

[247] S. Kanehashi, M. Kishida, T. Kidesaki, R. Shindo, S. Sato, T. Miyakoshi, K. Nagai, $\mathrm{CO}_{2}$ separation properties of a glassy aromatic polyimide composite membranes containing high-content 1-butyl-3methylimidazolium bis(trifluoromethylsulfonyl)imide ionic liquid, J. Membr. Sci. 430 (2013) 211-222. doi:10.1016/j.memsci.2012.12.003.

[248] H. Deligöz, M. Yılmazoğlu, Development of a new highly conductive and thermomechanically stable complex membrane based on sulfonated polyimide/ionic liquid for high temperature anhydrous fuel cells, J. Power Sources. 196 (2011) 3496-3502. doi:10.1016/j.jpowsour.2010.12.033.

[249] E.P. Favvas, F.K. Katsaros, S.K. Papageorgiou, A.A. Sapalidis, A.C. Mitropoulos, A review of the latest development of polyimide based membranes for $\mathrm{CO}_{2}$ separations, React. Funct. Polym. 120 (2017) 104-130. doi:10.1016/j.reactfunctpolym.2017.09.002.

[250] E.M. Erdni-Goryaev, A.Y. Alent'ev, N.A. Belov, D.O. Ponkratov, A.S. Shaplov, E.I. Lozinskaya, Y.S. Vygodskii, Gas separation characteristics of new membrane materials based on poly(ethylene glycol)crosslinked polymers and ionic liquids, Pet. Chem. 52 (2012) 494-498. doi:10.1134/S0965544112070031.

[251] P. Bernardo, J.C. Jansen, F. Bazzarelli, F. Tasselli, A. Fuoco, K. Friess, P. Izák, V. Jarmarová, M. Kačírková, G. Clarizia, Gas transport properties of Pebax®/room temperature ionic liquid gel membranes, Sep. Purif. Technol. 97 (2012) 73-82. doi:10.1016/j.seppur.2012.02.041.

[252] A. Khakpay, P. Scovazzo, Reverse-selective behavior of room temperature ionic liquid based membranes for natural gas processing, J. Membr. Sci. 545 (2018) 204-212. doi:10.1016/j.memsci.2017.09.068.

[253] S. Yoo, J. Won, S.W. Kang, Y.S. Kang, S. Nagase, $\mathrm{CO}_{2}$ separation membranes using ionic liquids in a Nafion matrix, J. Membr. Sci. 363 (2010) 72-79. doi:10.1016/j.memsci.2010.07.013.

[254] E. Ghasemi Estahbanati, M. Omidkhah, A. Ebadi Amooghin, Preparation and characterization of novel Ionic liquid/Pebax membranes for efficient CO2/light gases separation, J. Ind. Eng. Chem. 51 (2017) 77-89. 
doi:10.1016/j.jiec.2017.02.017.

[255] D. Nikolaeva, I. Azcune, M. Tanczyk, K. Warmuzinski, M. Jaschik, M. Sandru, P.I. Dahl, A. Genua, S. Loïs, E. Sheridan, A. Fuoco, I.F.J. Vankelecom, The performance of affordable and stable cellulose-based poly-ionic membranes in $\mathrm{CO}_{2} / \mathrm{N}_{2}$ and $\mathrm{CO}_{2} / \mathrm{CH}_{4}$ gas separation, J. Membr. Sci. 564 (2018) 552-561. doi:10.1016/j.memsci.2018.07.057.

[256] W. He, F. Zhang, Z. Wang, W. Sun, Z. Zhou, Z. Ren, Facilitated Separation of $\mathrm{CO}_{2}$ by Liquid Membranes and Composite Membranes with Task-Specific Ionic Liquids, Ind. Eng. Chem. Res. 55 (2016) 12616-12631. doi:10.1021/acs.iecr.6b02778.

[257] R. Nasir, H. Mukhtar, Z. Man, B.K. Dutta, M.S. Shaharun, M.Z. Abu Bakar, Mixed matrix membrane performance enhancement using alkanolamine solution, J. Membr. Sci. 483 (2015) 84-93. doi:10.1016/j.memsci.2015.02.041.

[258] K. Halder, M.M. Khan, J. Grünauer, S. Shishatskiy, C. Abetz, V. Filiz, V. Abetz, Blend membranes of ionic liquid and polymers of intrinsic microporosity with improved gas separation characteristics, J. Membr. Sci. 539 (2017) 368-382. doi:10.1016/j.memsci.2017.06.022.

[259] A. Alkhouzaam, M. Khraisheh, M. Atilhan, S.A. Al-Muhtaseb, L. Qi, D. Rooney, High-pressure $\mathrm{CO}_{2}$ $/ \mathrm{N}_{2}$ and $\mathrm{CO}_{2} / \mathrm{CH}_{4}$ separation using dense polysulfone-supported ionic liquid membranes, J. Nat. Gas Sci. Eng. 36 (2016) 472-485. doi:10.1016/j.jngse.2016.10.061.

[260] P. Cserjési, N. Nemestóthy, K. Bélafi-Bakó, Gas separation properties of supported liquid membranes prepared with unconventional ionic liquids, J. Membr. Sci. 349 (2010) 6-11. doi:10.1016/j.memsci.2009.10.044.

[261] L.A. Neves, J.G. Crespo, I.M. Coelhoso, Gas permeation studies in supported ionic liquid membranes, J. Membr. Sci. 357 (2010) 160-170. doi:10.1016/j.memsci.2010.04.016.

[262] J.E. Bara, C.J. Gabriel, T.K. Carlisle, D.E. Camper, A. Finotello, D.L. Gin, R.D. Noble, Gas separations in fluoroalkyl-functionalized room-temperature ionic liquids using supported liquid membranes, Chem. Eng. J. 147 (2009) 43-50. doi:10.1016/j.cej.2008.11.021.

[263] A. Ilyas, N. Muhammad, M.A. Gilani, I.F.J. Vankelecom, A.L. Khan, Effect of zeolite surface modification with ionic liquid [APTMS][Ac] on gas separation performance of mixed matrix membranes, Sep. Purif. Technol. 205 (2018) 176-183. doi:10.1016/j.seppur.2018.05.040.

[264] N. Kosinov, J. Gascon, F. Kapteijn, E.J.M. Hensen, Recent developments in zeolite membranes for gas separation, J. Membr. Sci. 499 (2016) 65-79. doi:10.1016/j.memsci.2015.10.049.

[265] G. Huang, A.P. Isfahani, A. Muchtar, K. Sakurai, B.B. Shrestha, D. Qin, D. Yamaguchi, E. Sivaniah, B. Ghalei, Pebax/ionic liquid modified graphene oxide mixed matrix membranes for enhanced $\mathrm{CO}_{2}$ capture, J. Membr. Sci. 565 (2018) 370-379. doi:10.1016/j.memsci.2018.08.026.

[266] A. Nuhnen, D. Dietrich, S. Millan, C. Janiak, Role of Filler Porosity and Filler/Polymer Interface Volume in Metal-Organic Framework/Polymer Mixed-Matrix Membranes for Gas Separation, ACS Appl. Mater. Interfaces. 10 (2018) 33589-33600. doi:10.1021/acsami.8b12938.

[267] R. Nasir, N.N.R. Ahmad, H. Mukhtar, D.F. Mohshim, Effect of ionic liquid inclusion and aminofunctionalized SAPO-34 on the performance of mixed matrix membranes for $\mathrm{CO}_{2} / \mathrm{CH}_{4}$ separation, J. Environ. Chem. Eng. 6 (2018) 2363-2368. doi:10.1016/j.jece.2018.03.032.

[268] M. Bhattacharya, M.K. Mandal, Synthesis and characterization of ionic liquid based mixed matrix membrane for acid gas separation, J. Clean. Prod. 156 (2017) 174-183. doi:10.1016/j.jclepro.2017.04.034. [269] J. Abraham, T. Jose, G. Moni, S.C. George, N. Kalarikkal, S. Thomas, Ionic liquid modified multiwalled carbon nanotube embedded styrene butadiene rubber membranes for the selective removal of toluene from toluene/methanol mixture via pervaporation, J. Taiwan Inst. Chem. Eng. (2018). 
doi:10.1016/j.jtice.2018.09.019.

[270] L. Hao, P. Li, T. Yang, T.-S. Chung, Room temperature ionic liquid/ZIF-8 mixed-matrix membranes for natural gas sweetening and post-combustion $\mathrm{CO}_{2}$ capture, J. Membr. Sci. 436 (2013) 221-231. doi:10.1016/j.memsci.2013.02.034.

[271] H. Li, L. Tuo, K. Yang, H.-K. Jeong, Y. Dai, G. He, W. Zhao, Simultaneous enhancement of mechanical properties and $\mathrm{CO}_{2}$ selectivity of ZIF-8 mixed matrix membranes: Interfacial toughening effect of ionic liquid, J. Membr. Sci. 511 (2016) 130-142. doi:10.1016/j.memsci.2016.03.050.

[272] M.G. Cowan, D.L. Gin, R.D. Noble, Poly(ionic liquid)/Ionic Liquid Ion-Gels with High "Free" Ionic Liquid Content: Platform Membrane Materials for $\mathrm{CO}_{2} /$ Light Gas Separations, Acc. Chem. Res. 49 (2016) 724-732. doi:10.1021/acs.accounts.5b00547.

[273] D.F. Mohshim, H. Mukhtar, Z. Man, A study on carbon dioxide removal by blending the ionic liquid in membrane synthesis, Sep. Purif. Technol. 196 (2018) 20-26. doi:10.1016/j.seppur.2017.06.034.

[274] M. Rezakazemi, A. Ebadi Amooghin, M.M. Montazer-Rahmati, A.F. Ismail, T. Matsuura, State-of-theart membrane based $\mathrm{CO}_{2}$ separation using mixed matrix membranes (MMMs): An overview on current status and future directions, Prog. Polym. Sci. 39 (2014) 817-861. doi:10.1016/j.progpolymsci.2014.01.003.

[275] P.S. Goh, A.F. Ismail, S.M. Sanip, B.C. Ng, M. Aziz, Recent advances of inorganic fillers in mixed matrix membrane for gas separation, Sep. Purif. Technol. 81 (2011) 243-264. doi:10.1016/j.seppur.2011.07.042.

[276] R.D. Noble, Perspectives on mixed matrix membranes, J. Membr. Sci. 378 (2011) 393-397. doi:10.1016/j.memsci.2011.05.031.

[277] Y. Ban, Z. Li, Y. Li, Y. Peng, H. Jin, W. Jiao, A. Guo, P. Wang, Q. Yang, C. Zhong, W. Yang, Confinement of Ionic Liquids in Nanocages: Tailoring the Molecular Sieving Properties of ZIF-8 for Membrane-Based $\mathrm{CO}_{2}$ Capture, Angew. Chem. Int. Ed. 54 (2015) 15483-15487. doi:10.1002/anie.201505508.

[278] P. Li, D.R. Paul, T.-S. Chung, High performance membranes based on ionic liquid polymers for $\mathrm{CO}_{2}$ separation from the flue gas, Green Chem. 14 (2012) 1052. doi:10.1039/c2gc16354c.

[279] Y.C. Hudiono, T.K. Carlisle, A.L. LaFrate, D.L. Gin, R.D. Noble, Novel mixed matrix membranes based on polymerizable room-temperature ionic liquids and SAPO-34 particles to improve $\mathrm{CO}_{2}$ separation, J. Membr. Sci. 370 (2011) 141-148. doi:10.1016/j.memsci.2011.01.012.

[280] Z.V. Singh, M.G. Cowan, W.M. McDanel, Y. Luo, R. Zhou, D.L. Gin, R.D. Noble, Determination and optimization of factors affecting $\mathrm{CO}_{2} / \mathrm{CH}_{4}$ separation performance in poly(ionic liquid)-ionic liquid-zeolite mixed-matrix membranes, J. Membr. Sci. 509 (2016) 149-155. doi:10.1016/j.memsci.2016.02.034.

[281] A. Eftekhari, T. Saito, Synthesis and properties of polymerized ionic liquids, Eur. Polym. J. 90 (2017) 245-272. doi:10.1016/j.eurpolymj.2017.03.033.

[282] Y. Men, D. Kuzmicz, J. Yuan, Poly(ionic liquid) colloidal particles, Curr. Opin. Colloid Interface Sci. 19 (2014) 76-83. doi:10.1016/j.cocis.2014.03.012.

[283] J. Yuan, M. Antonietti, Poly(ionic liquid)s: Polymers expanding classical property profiles, Polymer. 52 (2011) 1469-1482. doi:10.1016/j.polymer.2011.01.043.

[284] J. Yuan, D. Mecerreyes, M. Antonietti, Poly(ionic liquid)s: An update, Prog. Polym. Sci. 38 (2013) 1009-1036. doi:10.1016/j.progpolymsci.2013.04.002.

[285] J. Yuan, M. Fan, F. Zhang, Y. Xu, H. Tang, C. Huang, H. Zhang, Amine-functionalized poly(ionic liquid) brushes for carbon dioxide adsorption, Chem. Eng. J. 316 (2017) 903-910. doi:10.1016/j.cej.2017.02.035.

[286] P. Cardiano, O. Gómez-Laserna, P.G. Mineo, E. Furia, C. Triolo, S. Patanè, S. Lo Schiavo, Synthesis, $\mathrm{CO}_{2}$ sorption and capacitive properties of novel protic poly(ionic liquid)s, J. Mol. Liq. 241 (2017) 222-230. 
doi:10.1016/j.molliq.2017.06.013.

[287] L.C. Tomé, D. Mecerreyes, C.S.R. Freire, L.P.N. Rebelo, I.M. Marrucho, Pyrrolidinium-based polymeric ionic liquid materials: New perspectives for $\mathrm{CO}_{2}$ separation membranes, J. Membr. Sci. 428 (2013) 260-266. doi:10.1016/j.memsci.2012.10.044.

[288] L.C. Tomé, A.S.L. Gouveia, C.S.R. Freire, D. Mecerreyes, I.M. Marrucho, Polymeric ionic liquidbased membranes: Influence of polycation variation on gas transport and $\mathrm{CO}_{2}$ selectivity properties, J. Membr. Sci. 486 (2015) 40-48. doi:10.1016/j.memsci.2015.03.026.

[289] G. Zarca, W.J. Horne, I. Ortiz, A. Urtiaga, J.E. Bara, Synthesis and gas separation properties of poly(ionic liquid)-ionic liquid composite membranes containing a copper salt, J. Membr. Sci. 515 (2016) 109-114. doi:10.1016/j.memsci.2016.05.045.

[290] J.E. Bara, D.L. Gin, R.D. Noble, Effect of Anion on Gas Separation Performance of Polymer-RoomTemperature Ionic Liquid Composite Membranes, Ind. Eng. Chem. Res. 47 (2008) 9919-9924. doi:10.1021/ie801019x.

[291] J.E. Bara, S. Lessmann, C.J. Gabriel, E.S. Hatakeyama, R.D. Noble, D.L. Gin, Synthesis and Performance of Polymerizable Room-Temperature Ionic Liquids as Gas Separation Membranes, Ind. Eng. Chem. Res. 46 (2007) 5397-5404. doi:10.1021/ie0704492.

[292] S.T. Hemp, M. Zhang, M.H. Allen, S. Cheng, R.B. Moore, T.E. Long, Comparing Ammonium and Phosphonium Polymerized Ionic Liquids: Thermal Analysis, Conductivity, and Morphology, Macromol. Chem. Phys. 214 (2013) 2099-2107. doi:10.1002/macp.201300322.

[293] M.G. Cowan, M. Masuda, W.M. McDanel, Y. Kohno, D.L. Gin, R.D. Noble, Phosphonium-based poly(Ionic liquid) membranes: The effect of cation alkyl chain length on light gas separation properties and Ionic conductivity, J. Membr. Sci. 498 (2016) 408-413. doi:10.1016/j.memsci.2015.10.019.

[294] D. Şen, H. Kalıpçılar, L. Yilmaz, Development of polycarbonate based zeolite 4A filled mixed matrix gas separation membranes, J. Membr. Sci. 303 (2007) 194-203. doi:10.1016/j.memsci.2007.07.010.

[295] Shu, S. Husain, W.J. Koros, A General Strategy for Adhesion Enhancement in Polymeric Composites by Formation of Nanostructured Particle Surfaces, J. Phys. Chem. C. 111 (2007) 652-657. doi:10.1021/jp065711j.

[296] E. Rynkowska, K. Dzieszkowski, A. Lancien, K. Fatyeyeva, A. Szymczyk, J. Kujawa, S. Koter, S. Marais, A. Wolan, W. Kujawski, Physicochemical properties and pervaporation performance of dense membranes based on cellulose acetate propionate (CAP) and containing polymerizable ionic liquid (PIL), J. Membr. Sci. 544 (2017) 243-251. doi:10.1016/j.memsci.2017.09.031.

[297] E. Rynkowska, K. Fatyeyeva, J. Kujawa, K. Dzieszkowski, A. Wolan, W. Kujawski, The Effect of Reactive Ionic Liquid or Plasticizer Incorporation on the Physicochemical and Transport Properties of Cellulose Acetate Propionate-Based Membranes, Polymers. 10 (2018) 86. doi:10.3390/polym10010086.

[298] W. Zhao, Y. Tang, J. Xi, J. Kong, Functionalized graphene sheets with poly(ionic liquid)s and high adsorption capacity of anionic dyes, Appl. Surf. Sci. 326 (2015) 276-284. doi:10.1016/j.apsusc.2014.11.069. [299] Y. Wu, M. Regan, W. Zhang, J. Yuan, Reprocessable porous poly(ionic liquid) membranes derived from main-chain polyimidazolium, Eur. Polym. J. 103 (2018) 214-219. doi:10.1016/j.eurpolymj.2018.03.035.

[300] C. Zhang, W. Zhang, H. Gao, Y. Bai, Y. Sun, Y. Chen, Synthesis and gas transport properties of poly(ionic liquid) based semi-interpenetrating polymer network membranes for $\mathrm{CO}_{2} / \mathrm{N}_{2}$ separation, J. Membr. Sci. 528 (2017) 72-81. doi:10.1016/j.memsci.2017.01.022.

[301] H. Cong, B. Yu, J. Tang, X.S. Zhao, Ionic liquid modified poly(2,6-dimethyl-1,4-phenylene oxide) for $\mathrm{CO}_{2}$ separation, J. Polym. Res. 19 (2012) 9761. doi:10.1007/s10965-011-9761-9.

[302] K. Simons, K. Nijmeijer, J.E. Bara, R.D. Noble, M. Wessling, How do polymerized room-temperature 
ionic liquid membranes plasticize during high pressure $\mathrm{CO}_{2}$ permeation?, J. Membr. Sci. 360 (2010) 202 209. doi:10.1016/j.memsci.2010.05.018.

[303] L.C. Tomé, D.C. Guerreiro, R.M. Teodoro, V.D. Alves, I.M. Marrucho, Effect of polymer molecular weight on the physical properties and $\mathrm{CO}_{2} / \mathrm{N}_{2}$ separation of pyrrolidinium-based poly(ionic liquid) membranes, J. Membr. Sci. 549 (2018) 267-274. doi:10.1016/j.memsci.2017.12.019.

[304] L.M. Robeson, The upper bound revisited, J. Membr. Sci. 320 (2008) 390-400. doi:10.1016/j.memsci.2008.04.030.

[305] T. Sakaguchi, H. Ito, T. Masuda, T. Hashimoto, Highly $\mathrm{CO}_{2}$-permeable and -permselective poly(diphenylacetylene)s having imidazolium salts: Synthesis, characterization, gas permeation properties, and effects of counter anion, Polymer. 54 (2013) 6709-6715. doi:10.1016/j.polymer.2013.10.030.

[306] A.M. Lopez, M.G. Cowan, D.L. Gin, R.D. Noble, Phosphonium-Based Poly(ionic liquid)/Ionic Liquid Ion Gel Membranes: Influence of Structure and Ionic Liquid Loading on Ion Conductivity and Light Gas Separation Performance, J. Chem. Eng. Data. 63 (2018) 1154-1162. doi:10.1021/acs.jced.7b00541.

[307] W. Jeffrey Horne, M.A. Andrews, M.S. Shannon, K.L. Terrill, J.D. Moon, S.S. Hayward, J.E. Bara, Effect of branched and cycloalkyl functionalities on $\mathrm{CO}_{2}$ separation performance of poly(IL) membranes, Sep. Purif. Technol. 155 (2015) 89-95. doi:10.1016/j.seppur.2015.02.009.

[308] O. Vopička, L. Morávková, J. Vejražka, Z. Sedláková, K. Friess, P. Izák, Ethanol sorption and permeation in fluoropolymer gel membrane containing 1-ethyl-3-methylimidazolium bis(trifluoromethylsulfonyl)imide ionic liquid, Chem. Eng. Process. Process Intensif. 94 (2015) 72-77. doi:10.1016/j.cep.2015.02.008.

[309] V.A. Kusuma, M.K. Macala, J. Liu, A.M. Marti, R.J. Hirsch, L.J. Hill, D. Hopkinson, Ionic liquid compatibility in polyethylene oxide/siloxane ion gel membranes, J. Membr. Sci. 545 (2018) 292-300. doi:10.1016/j.memsci.2017.09.086.

[310] H.R. Mahdavi, N. Azizi, M. Arzani, T. Mohammadi, Improved $\mathrm{CO}_{2} / \mathrm{CH}_{4}$ separation using a nanocomposite ionic liquid gel membrane, J. Nat. Gas Sci. Eng. 46 (2017) 275-288. doi:10.1016/j.jngse.2017.07.024.

[311] S.H. K.p, M.S. Thayyil, S.K. Deshpande, J. T.v, J. Kolte, Development of ion conducting ionic liquidbased gel polymer electrolyte membrane PMMA/BMPyr.TFSI - With improved electrical, optical, thermal and structural properties, Solid State Ion. 310 (2017) 166-175. doi:10.1016/j.ssi.2017.08.012.

[312] A. Plaza, G. Merlet, A. Hasanoglu, M. Isaacs, J. Sanchez, J. Romero, Separation of butanol from ABE mixtures by sweep gas pervaporation using a supported gelled ionic liquid membrane: Analysis of transport phenomena and selectivity, J. Membr. Sci. 444 (2013) 201-212. doi:10.1016/j.memsci.2013.04.034.

[313] R.M. Couto, T. Carvalho, L.A. Neves, R.M. Ruivo, P. Vidinha, A. Paiva, I.M. Coelhoso, S. Barreiros, P.C. Simões, Development of Ion-Jelly® membranes, Sep. Purif. Technol. 106 (2013) 22-31. doi:10.1016/j.seppur.2012.12.026.

[314] K. Friess, M. Lanč, K. Pilnáček, V. Fíla, O. Vopička, Z. Sedláková, M.G. Cowan, W.M. McDanel, R.D. Noble, D.L. Gin, P. Izak, $\mathrm{CO}_{2} / \mathrm{CH}_{4}$ separation performance of ionic-liquid-based epoxy-amine ion gel membranes under mixed feed conditions relevant to biogas processing, J. Membr. Sci. 528 (2017) 64-71. doi:10.1016/j.memsci.2017.01.016.

[315] F. Moghadam, E. Kamio, H. Matsuyama, High $\mathrm{CO}_{2}$ separation performance of amino acid ionic liquidbased double network ion gel membranes in low $\mathrm{CO}_{2}$ concentration gas mixtures under humid conditions, J. Membr. Sci. 525 (2017) 290-297. doi:10.1016/j.memsci.2016.12.002.

[316] K.C. Khulbe, T. Matsuura, Recent progress in polymeric hollow-fibre membrane preparation and applications, Membr. Technol. 2016 (2016) 7-13. doi:10.1016/S0958-2118(16)30149-5. 
[317] A.L. Ahmad, T.A. Otitoju, B.S. Ooi, Hollow fiber (HF) membrane fabrication: A review on the effects of solution spinning conditions on morphology and performance, J. Ind. Eng. Chem. (2018). doi:10.1016/j.jiec.2018.10.005.

[318] I. Ullah Khan, M.H.D. Othman, A.F. Ismail, T. Matsuura, H. Hashim, N.A.H.M. Nordin, M.A. Rahman, J. Jaafar, A. Jilani, Status and improvement of dual-layer hollow fiber membranes via co-extrusion process for gas separation: A review, J. Nat. Gas Sci. Eng. 52 (2018) 215-234. doi:10.1016/j.jngse.2018.01.043.

[319] H.-A. Tsai, C.-Y. Hsu, S.-H. Huang, K.-R. Lee, W.-S. Hung, C.-C. Hu, J.-Y. Lai, The preparation of polyelectrolyte/hydrolyzed polyacrylonitrile composite hollow fiber membrane for pervaporation, J. Taiwan Inst. Chem. Eng. 91 (2018) 623-633. doi:10.1016/j.jtice.2018.06.023.

[320] F. Zhang, W. Sun, J. Liu, W. Zhang, Z. Ren, Extraction separation of toluene/cyclohexane with hollow fiber supported ionic liquid membrane, Korean J. Chem. Eng. 31 (2014) 1049-1056. doi:10.1007/s11814014-0021-7.

[321] S. Wickramanayake, D. Hopkinson, C. Myers, L. Sui, D. Luebke, Investigation of transport and mechanical properties of hollow fiber membranes containing ionic liquids for pre-combustion carbon dioxide capture, J. Membr. Sci. 439 (2013) 58-67. doi:10.1016/j.memsci.2013.03.039.

[322] S. Wickramanayake, D. Hopkinson, C. Myers, L. Hong, J. Feng, Y. Seol, D. Plasynski, M. Zeh, D. Luebke, Mechanically robust hollow fiber supported ionic liquid membranes for $\mathrm{CO}_{2}$ separation applications, J. Membr. Sci. 470 (2014) 52-59. doi:10.1016/j.memsci.2014.07.015.

[323] B. Ulrich, T.C. Frank, A. McCormick, E.L. Cussler, Membrane-assisted VOC removal from aqueous acrylic latex, J. Membr. Sci. 452 (2014) 426-432. doi:10.1016/j.memsci.2013.10.025.

[324] M. Drobek, A. Figoli, S. Santoro, N. Navascués, J. Motuzas, S. Simone, C. Algieri, N. Gaeta, L. Querze, A. Trotta, G. Barbieri, R. Mallada, A. Julbe, E. Drioli, PVDF-MFI mixed matrix membranes as VOCs adsorbers, Microporous Mesoporous Mater. 207 (2015) 126-133. doi:10.1016/j.micromeso.2015.01.005.

[325] C. Feng, K.C. Khulbe, S. Tabe, Volatile organic compound removal by membrane gas stripping using electro-spun nanofiber membrane, Desalination. 287 (2012) 98-102. doi:10.1016/j.desal.2011.04.074.

[326] H. Banazadeh, S.M. Mousavi, A novel process for oxygen absorption from air using hollow fiber gasliquid membrane contactor, Sep. Purif. Technol. 193 (2018) 283-288. doi:10.1016/j.seppur.2017.10.059.

[327] C.A. Scholes, D. deMontigny, S.E. Kentish, G.W. Stevens, Regenerating Membrane Contactors for Solvent Absorption, Energy Procedia. 114 (2017) 642-649. doi:10.1016/j.egypro.2017.03.1208.

[328] S. Zhao, P.H.M. Feron, L. Deng, E. Favre, E. Chabanon, S. Yan, J. Hou, V. Chen, H. Qi, Status and progress of membrane contactors in post-combustion carbon capture: A state-of-the-art review of new developments, J. Membr. Sci. 511 (2016) 180-206. doi:10.1016/j.memsci.2016.03.051.

[329] M. Darestani, V. Haigh, S.J. Couperthwaite, G.J. Millar, L.D. Nghiem, Hollow fibre membrane contactors for ammonia recovery: Current status and future developments, J. Environ. Chem. Eng. 5 (2017) 1349-1359. doi:10.1016/j.jece.2017.02.016.

[330] A. Nogalska, M. Ammendola, B. Tylkowski, V. Ambrogi, R. Garcia-Valls, Ambient $\mathrm{CO}_{2}$ adsorption via membrane contactors - Value of assimilation from air as nature stomata, J. Membr. Sci. 546 (2018) 41-49. doi:10.1016/j.memsci.2017.10.007.

[331] H. Pang, H. Gong, M. Du, Q. Shen, Z. Chen, Effect of non-solvent additive concentration on $\mathrm{CO}_{2}$ absorption performance of polyvinylidenefluoride hollow fiber membrane contactor, Sep. Purif. Technol. 191 (2018) 38-47. doi:10.1016/j.seppur.2017.09.012.

[332] S. Rostami, P. Keshavarz, S. Raeissi, Experimental study on the effects of an ionic liquid for $\mathrm{CO}_{2}$ capture using hollow fiber membrane contactors, Int. J. Greenh. Gas Control. 69 (2018) 1-7. doi:10.1016/j.ijggc.2017.12.002. 
[333] G.K. Agrahari, N. Pandey, N. Verma, P.K. Bhattacharya, Membrane contactor for reactive extraction of succinic acid from aqueous solution by tertiary amine, Chem. Eng. Res. Des. 92 (2014) 2705-2714. doi:10.1016/j.cherd.2014.01.021.

[334] L. Ansaloni, R. Rennemo, H.K. Knuutila, L. Deng, Development of membrane contactors using volatile amine-based absorbents for $\mathrm{CO}_{2}$ capture: Amine permeation through the membrane, J. Membr. Sci. 537 (2017) 272-282. doi:10.1016/j.memsci.2017.05.016.

[335] A.F. Portugal, F.D. Magalhães, A. Mendes, Carbon dioxide removal from anaesthetic gas circuits using hollow fiber membrane contactors with amino acid salt solutions, J. Membr. Sci. 339 (2009) 275-286. doi:10.1016/j.memsci.2009.04.055.

[336] B. Rezaei, S. Riahi, Prediction of $\mathrm{CO}_{2}$ loading of amines in carbon capture process using membrane contactors: A molecular modeling, J. Nat. Gas Sci. Eng. 33 (2016) 388-396. doi:10.1016/j.jngse.2016.05.003. [337] J. Cabral, I. Pantateão, S. Rodrigues, M. Catarino, F. Magalhães, A. Mendes, Kinetics of the Carbon Dioxide Absorption and Desorption with Amino Acid Salt Solutions using Hollow Fiber Membrane Contactors, Procedia Eng. 44 (2012) 1223-1224. doi:10.1016/j.proeng.2012.08.733.

[338] M. Malankowska, C.F. Martins, H.S. Rho, L.A. Neves, R.M. Tiggelaar, J.G. Crespo, M.P. Pina, R. Mallada, H. Gardeniers, I.M. Coelhoso, Microfluidic devices as gas - Ionic liquid membrane contactors for $\mathrm{CO}_{2}$ removal from anaesthesia gases, J. Membr. Sci. 545 (2018) 107-115. doi:10.1016/j.memsci.2017.09.065. [339] J.K.J. Yong, G.W. Stevens, F. Caruso, S.E. Kentish, The resilience of carbonic anhydrase enzyme for membrane-based carbon capture applications, Int. J. Greenh. Gas Control. 62 (2017) 122-129. doi:10.1016/j.ijggc.2017.04.006.

[340] E.E. Licon Bernal, C. Maya, C. Valderrama, J.L. Cortina, Valorization of ammonia concentrates from treated urban wastewater using liquid-liquid membrane contactors, Chem. Eng. J. 302 (2016) 641-649. doi:10.1016/j.cej.2016.05.094.

[341] A. Hasanoğlu, J. Romero, B. Pérez, A. Plaza, Ammonia removal from wastewater streams through membrane contactors: Experimental and theoretical analysis of operation parameters and configuration, Chem. Eng. J. 160 (2010) 530-537. doi:10.1016/j.cej.2010.03.064.

[342] H. Liu, J. Wang, Separation of ammonia from radioactive wastewater by hydrophobic membrane contactor, Prog. Nucl. Energy. 86 (2016) 97-102. doi:10.1016/j.pnucene.2015.10.011.

[343] K. Snochowska, M. Tylman, W. Kamiński, Ethanol Recovery from Low-Concentration Aqueous Solutions Using Membrane Contactors with Ionic Liquids, Ecol. Chem. Eng. S. 22 (2015) 565-575. doi:10.1515/eces-2015-0033.

[344] Z. Zhang, X. Wu, L. Wang, B. Zhao, J. Li, H. Zhang, Wetting mechanism of a PVDF hollow fiber membrane in immersed membrane contactors for $\mathrm{CO}_{2}$ capture in the presence of monoethanolamine, RSC Adv. 7 (2017) 13451-13457. doi:10.1039/C6RA28563E.

[345] P. Tantikhajorngosol, N. Laosiripojana, R. Jiraratananon, S. Assabumrungrat, A modeling study of module arrangement and experimental investigation of single stage module for physical absorption of biogas using hollow fiber membrane contactors, J. Membr. Sci. 549 (2018) 283-294. doi:10.1016/j.memsci.2017.12.014.

[346] F. Porcheron, D. Ferré, E. Favre, P.T. Nguyen, O. Lorain, R. Mercier, L. Rougeau, Hollow fiber membrane contactors for $\mathrm{CO}_{2}$ capture: From lab-scale screening to pilot-plant module conception, Energy Procedia. 4 (2011) 763-770. doi:10.1016/j.egypro.2011.01.117.

[347] G.S.M.D.P. Sethunga, W. Rongwong, R. Wang, T.-H. Bae, Optimization of hydrophobic modification parameters of microporous polyvinylidene fluoride hollow-fiber membrane for biogas recovery from anaerobic membrane bioreactor effluent, J. Membr. Sci. 548 (2018) 510-518. 
doi:10.1016/j.memsci.2017.11.059.

[348] Y. Xu, Y. Lin, N.G.P. Chew, C. Malde, R. Wang, Biocatalytic PVDF composite hollow fiber membranes for $\mathrm{CO}_{2}$ removal in gas-liquid membrane contactor, J. Membr. Sci. 572 (2019) 532-544. doi:10.1016/j.memsci.2018.11.043.

[349] A. Ortiz, D. Gorri, Á. Irabien, I. Ortiz, Separation of propylene/propane mixtures using Ag+-RTIL solutions. Evaluation and comparison of the performance of gas-liquid contactors, J. Membr. Sci. 360 (2010) 130-141. doi:10.1016/j.memsci.2010.05.013.

[350] A.V. Perdikaki, A.I. Labropoulos, E. Siranidi, I. Karatasios, N. Kanellopoulos, N. Boukos, P. Falaras, G.N. Karanikolos, G.E. Romanos, Efficient CO oxidation in an ionic liquid-modified, Au nanoparticleloaded membrane contactor, Chem. Eng. J. 305 (2016) 79-91. doi:10.1016/j.cej.2015.11.111.

[351] P. Luis, A. Garea, A. Irabien, Zero solvent emission process for sulfur dioxide recovery using a membrane contactor and ionic liquids, J. Membr. Sci. 330 (2009) 80-89. doi:10.1016/j.memsci.2008.12.046. [352] J. Albo, P. Luis, A. Irabien, Absorption of coal combustion flue gases in ionic liquids using different membrane contactors, Desalination Water Treat. 27 (2011) 54-59. doi:10.5004/dwt.2011.2050.

[353] Z. Dai, L. Deng, Membrane absorption using ionic liquid for pre-combustion $\mathrm{CO}_{2}$ capture at elevated pressure and temperature, Int. J. Greenh. Gas Control. 54 (2016) 59-69. doi:10.1016/j.ijggc.2016.09.001. [354] Z. Dai, M. Usman, M. Hillestad, L. Deng, Modelling of a tubular membrane contactor for precombustion $\mathrm{CO}_{2}$ capture using ionic liquids: Influence of the membrane configuration, absorbent properties and operation parameters, Green Energy Environ. 1 (2016) 266-275. doi:10.1016/j.gee.2016.11.006.

[355] S. Mosadegh-Sedghi, D. Rodrigue, J. Brisson, M.C. Iliuta, Wetting phenomenon in membrane contactors - Causes and prevention, J. Membr. Sci. 452 (2014) 332-353. doi:10.1016/j.memsci.2013.09.055. [356] E. Guillen-Burrieza, M.O. Mavukkandy, M.R. Bilad, H.A. Arafat, Understanding wetting phenomena in membrane distillation and how operational parameters can affect it, J. Membr. Sci. 515 (2016) 163-174. doi:10.1016/j.memsci.2016.05.051.

[357] S. Bazhenov, A. Malakhov, D. Bakhtin, V. Khotimskiy, G. Bondarenko, V. Volkov, M. Ramdin, T.J.H. Vlugt, A. Volkov, $\mathrm{CO}_{2}$ stripping from ionic liquid at elevated pressures in gas-liquid membrane contactor, Int. J. Greenh. Gas Control. 71 (2018) 293-302. doi:10.1016/j.ijggc.2018.03.001.

[358] L. Gomez-Coma, A. Garea, A. Irabien, Carbon dioxide capture by [emim][Ac] ionic liquid in a polysulfone hollow fiber membrane contactor, Int. J. Greenh. Gas Control. 52 (2016) 401-409. doi:10.1016/j.ijggc.2016.07.019.

[359] Z. Dai, L. Ansaloni, L. Deng, Precombustion $\mathrm{CO}_{2}$ Capture in Polymeric Hollow Fiber Membrane Contactors Using Ionic Liquids: Porous Membrane versus Nonporous Composite Membrane, Ind. Eng. Chem. Res. 55 (2016) 5983-5992. doi:10.1021/acs.iecr.6b01247.

[360] R. Bogel-Lukasik, Ionic Liquids in the Biorefinery Concept: Challenges and Perspectives, Royal Society of Chemistry, 2015.

[361] T.P.T. Pham, C.-W. Cho, Y.-S. Yun, Environmental fate and toxicity of ionic liquids: a review, Water Res. 44 (2010) 352-372. doi:10.1016/j.watres.2009.09.030.

[362] K.M. Docherty, M.V. Joyce, K.J. Kulacki, C.F. Kulpa, Microbial biodegradation and metabolite toxicity of three pyridinium-based cation ionic liquids, Green Chem. 12 (2010) 701-712. doi:10.1039/B919154B. 